Andrews University

Digital Commons @ Andrews University

2015

\title{
A Strategic Marketing Plan for Community Ministries at the Toronto West Seventh-day Adventist Church
}

Allan Roy Chichester

Andrews University

Follow this and additional works at: https://digitalcommons.andrews.edu/dmin

Part of the Practical Theology Commons

\section{Recommended Citation}

Chichester, Allan Roy, "A Strategic Marketing Plan for Community Ministries at the Toronto West Seventhday Adventist Church" (2015). Professional Dissertations DMin. 438.

https://dx.doi.org/10.32597/dmin/438

https://digitalcommons.andrews.edu/dmin/438

This Project Report is brought to you for free and open access by the Graduate Research at Digital Commons @ Andrews University. It has been accepted for inclusion in Professional Dissertations DMin by an authorized administrator of Digital Commons @ Andrews University. For more information, please contact repository@andrews.edu. 
ABSTRACT

A STRATEGIC MARKETING PLAN FOR COMMUNITY MINISTRIES AT THE TORONTO WEST SEVENTHDAY ADVENTIST CHURCH

by

Allan Roy Chichester

Adviser: David Penno 


\author{
ABSTRACT OF GRADUATE STUDENT RESEARCH \\ Project Document \\ Andrews University \\ Seventh-day Adventist Theological Seminary
}

\begin{abstract}
Title: A STRATEGIC MARKETING PLAN FOR COMMUNITY MINISTRIES AT THE TORONTO WEST SEVENTH-DAY ADVENTIST CHURCH

Name of researcher: Allan Roy Chichester

Name and degree of faculty adviser: David Penno, PhD

Date completed: May 2015
\end{abstract}

Problem

The Toronto West Seventh-day Adventist Church is a large church that has a membership of 1,306, located in a very diverse urban community of Etobicoke North in Toronto, with variety in ethnicity, language, culture and religion. In the church's neighborhood, there is a growing immigrant population that is currently in flux due to the constant demographic transition. This certainly poses a number of challenges for this church because there are so many varying ethnic and cultural groups that make ministering to this community very difficult. The church has tried to reach its neighbours by hosting community services events such as a free mid-week community supper and an 
annual thanksgiving dinner; however, many of the community services events are not well attended by people from the community.

\section{Method}

In this project, marketing research was used to develop and implement a strategic marketing plan for the Community Ministries Department at the Toronto West Seventhday Adventist Church. The process included acquiring information from primary and secondary sources, and the results of the data analysis were used to develop and implement a sound and effective marketing strategy. The effectiveness of the marketing strategy was also analyzed for rate of success.

\section{Results}

The development and implementation of a strategic marketing plan for the Community Services Department led to an increase in attendance of over $300 \%$ to a sponsored program of the department. It also led to the identification of recommendations to help the church become more effective in its mission to reach the community.

\section{Conclusions}

Strategic marketing can be used to help churches become more effective in the accomplishment of their mission. It can be used to market programs and services that address the welfare needs of the community. 
Andrews University

Seventh-day Adventist Theological Seminary

\title{
A STRATEGIC MARKETING PLAN FOR COMMUNITY MINISTRIES AT THE TORONTO WEST SEVENTH- DAY ADVENTIST CHURCH
}

\author{
A Project Document \\ Presented in Partial Fulfillment \\ of the Requirements for the Degree \\ Doctor of Ministry
}

by

Allan Roy Chichester

May 2015 
(C) Copyright by Allan Roy Chichester 2015

All Rights Reserved 


\title{
A STRATEGIC MARKETING PLAN FOR COMMUNITY MINISTRIES AT THE TORONTO WEST SEVENTH- \\ DAY ADVENTIST CHURCH
}

\author{
A project document \\ presented in partial fulfillment \\ of the requirements for the degree \\ Doctor of Ministry
}

by

Allan Roy Chichester

APPROVAL BY THE COMMITTEE:

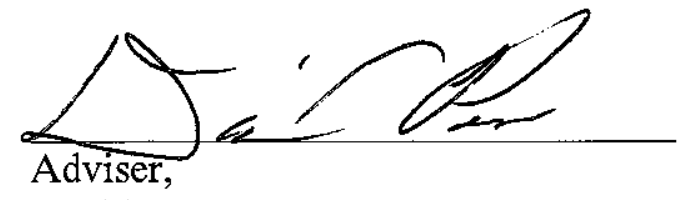

David Penno

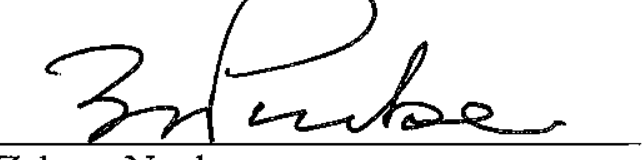

Zebron Ncube

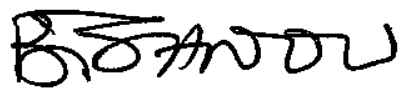

Boubakar Sanou

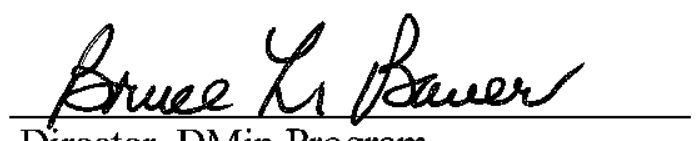

Director, DMin Program

Bruce L. Bauer

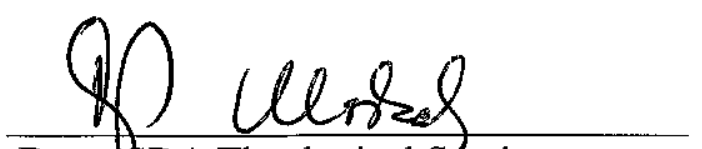

Dean, \$DA Theological Seminary Jiří Moskala

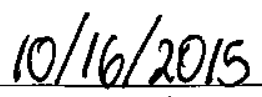

Date approved 


\section{DEDICATION}

This project is dedicated to my wife Lauren, who has been a source of inspiration and encouragement in my life, and to my mother Jenny, who made a great sacrifice to ensure that I receive a secondary education. 


\section{TABLE OF CONTENTS}

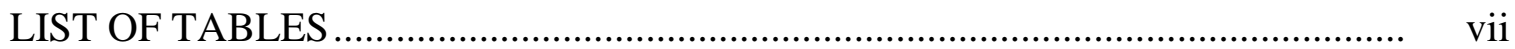

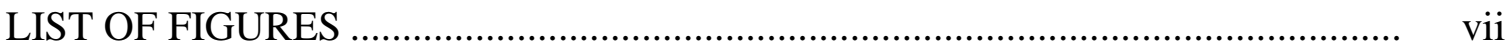

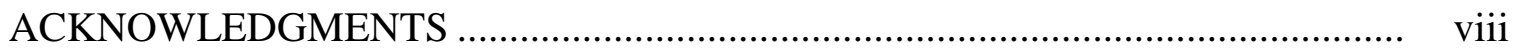

Chapter

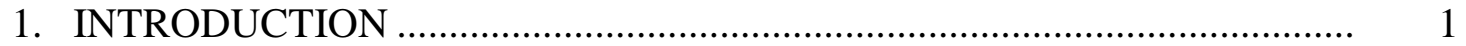

Background to the Problem ................................................................ 1

History of Toronto West Seventh-day Adventist Church.............. 1

Current Context of the Church..................................................... 4

Comparison of Church and Community ...................................... 5

The Problem ..................................................................................... 6

Purpose of the Project ......................................................................... 7

Justification for This Project ............................................................. 7

Overview of the Project .................................................................. 8

Expectations for This Project.......................................................... 9

Limitations of This Project .............................................................. 10

Definition of Terms......................................................................... 10

2. BIBLICAL/THEOLOGICAL FOUNDATIONS INTRODUCTION .............. 12

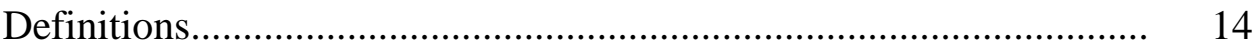

Key Terms............................................................................... 17

Old Testament Foundations ............................................................ 18

The Mission of People Outside of Israel..................................... 18

The Mission of People Inside of Israel ....................................... 20

The Law of the Seventh-Year Release................................... 21

The Law Prohibiting Interest ................................................. 22

The Jubilee .............................................................................. 22

The Law of Gleaning ............................................................... 25

The use of the Tithe in the Third Year..................................... 25

The Payment of Wages ........................................................... 26

The Reminders and Warnings of the Prophets ...................... 26

New Testament Foundations........................................................... 28

The Mission of Jesus..................................................................... 28

The Mission Beyond Israel ...................................................... $\quad 30$ 
The Story of the Good Samaritan-A Boundless Mission

Paradigm

The Mission of the Early Church.................................................. 33

The Mission Inside the Church ................................................ 33

The Story of Dorcas-A Boundless Mission Paradigm ........... 35

The Mission of Paul and James ............................................ 36

A Theology for Community Ministries for Toronto West

Seventh-day Adventist Church .................................................... 37

Conclusion

3. LITERATURE RELATED TO STRATEGIC MARKET PLANNING

Definitions of Marketing, Strategic Marketing and Strategic

Market Planning

Marketing

Strategic Marketing and Strategic Market Planning....

The Strategic Marketing Planning Process: An Overview ................. 50

The Situation Analysis .............................................................. 54

The Development of Strategy ................................................... 55

The Implementation and Control ............................................ 57

Marketing for Churches ................................................................. 59

Those who Support Church Marketing...................................... 59

Those who do not Support Church Marketing............................ 60

Churches can use Marketing.................................................... 61

Strategic Marketing for Churches ................................................ 61

Summary and Conclusion .............................................................. 63

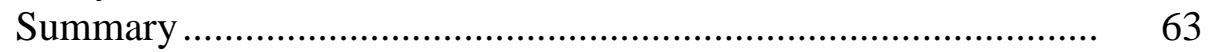

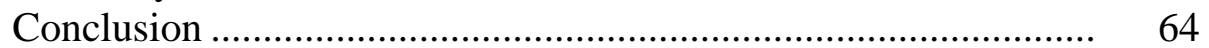

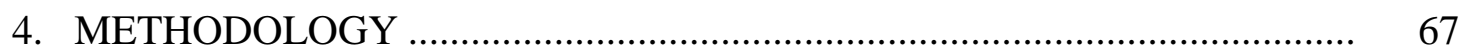

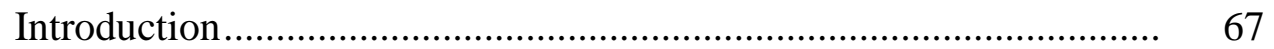

The Background to the Study .......................................................... 68

The Qualitative Method .................................................................. 69

The Subjects or Participants............................................................ 71

The Strategic Marketing Planning Process ........................................ 72

Mission Statement and the Situation Analysis............................ 72

Opportunities and Threats................................................. 75

The Interviews ....................................................................... 76

Strategy Development............................................................. 79

Implementation and Control ...................................................... 83

Conclusion ....................................................................... 83

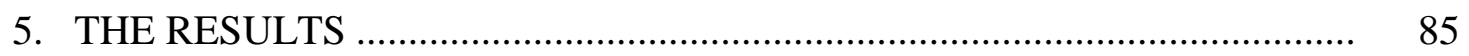

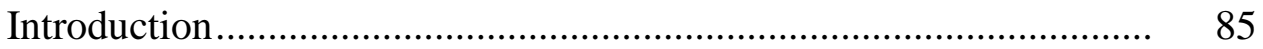


Situation Analysis and its Results................................................... 84

Strengths and Weaknesses ......................................................... 86

Opportunities and Threats......................................................... 86

Results of the Situation Analysis .................................................. 88

Poverty and Needs ................................................................. 93

Strategy Development and its Results ............................................... 95

Results of Strategy Development................................................... 99

Strategic Marketing Plan for Community Ministries..................... $\quad 99$

Implementation, Control, and Results ............................................... 102

Conclusion .............................................................................. 104

6. SUMMARY, CONCLUSIONS, AND RECOMMENDATIONS.................... 106

Summary and Conclusions ............................................................. 106

Recommendations ....................................................................... 112

For Toronto West Seventh-day Adventist Church......................... 112

For Other Churches..................................................................... 114

Implication for Further Research ....................................................... 115

How I Have Grown Through This Project........................................... 115

Appendix

A. INFORMED CONSENT LETTER …….......................................... 117

B. RESEARCH INSTRUMENT ............................................................ 119

C. REGISTRATION FORM ............................................................. 121

D. IRB EXEMPTION LETTER …………………................................ 123

E. EXPERIENCE THE LOVE FLIER ………....................................... 125

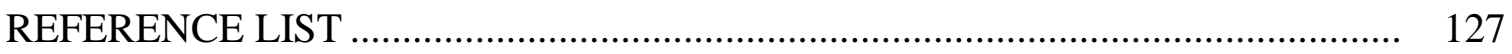

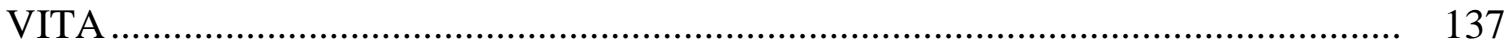




\section{LIST OF TABLES}

1. Top 10 Real Needs of Etobicoke North Based on Number of Persons Listing Them

2. Top 10 Felt Needs of Etobicoke North Based on Number of Persons Listing Them

3. Frequency Ranking and Calculated Scores for Items Under Real Needs............ 88

4. Frequency Ranking and Calculated Scores for Items Under Felt Needs............. 89

5. Ways People Learned About the Program...................................................... 102

\section{LIST OF FIGURES}

1. Strategic Organizational Marketing Planning Process ................................... 50

2. The Business Strategic_-Planning Process .................................................. 50 


\section{ACKNOWLEDGEMENTS}

I wish to recognize a number of individuals who contributed towards the writing of this project. Without their kindness, patience, timely encouragement, thoughtful suggestions, and assistance, this accomplishment would not have been possible. I would like to thank Dr. David Penno, my adviser, for his encouragement, wise suggestions, kind help, and reminders during this project. I am grateful to Zebron Ncube, my second reader, for his consideration and review, as I journeyed through the project. I would also like to acknowledge Dr. Skip Bell, Director of the Doctor of Ministry program, for his consistent encouragement and reminders about timelines.

To my editors Averil Kurtz, Camille Clayton, and Laren Kurtz, I thank you for your untiring efforts as you edited this document. I thank colleagues in the Doctor of Ministry work group, Marian Kossovan, Petras Bahadur, Renee Sanchez, and Gration Perera for their prayers and encouragement during this journey. I would like to acknowledge the Doctor of Ministry context support group for their timely advice about conducting this research. Thanks to Dr. Howard Olver, Dr. Nephtaly Dorzilme, Dr. Clarence Baptiste, Pastor Jakov Bibulovic, Pastor Carton Roulston, Pastor Antonio Bueno, and Elder Stanley Onoyebia who were the members of the context support group.

Thanks to Mrs. Gloria Samuels and the other leaders of the Community Services Department of the Toronto West Seventh-day Adventist church for the many hours they spent helping me to make the project successful. Thanks to the pastoral staff, Church 
Board, the members of the Toronto West Seventh-day Adventist Church, the pastoral staff, Church Board, and members of the Toronto Central Seventh-day Adventist Church for their help while I was working on this project.

To Dr. Hilton Garnett, Dr. Christopher Montrose, Dr. Lionel Matthews, Dr. Janice Maitland, Dr. Lazarus Castang, and Mr. Marlon Sargeant, I am ever grateful for your motivation.

Thanks to Dr. Marcel Sargeant and Dr. Bruce Wrenn who helped me to clarify many aspects of this project.

I would like to acknowledge the administration of the Ontario Conference: Dr. Mansfield Edwards, president; Dr. Dan Linrud, former executive secretary; Elder Gary Hodder, executive secretary; and Elder Ulysses Guarin, treasurer for their support towards the completion of this project.

My heartfelt gratitude to Dr. Kirsty Duncan, MP for Etobicoke North, Canada, and her staff; and Councilor Vincent Crisanti, Deputy Mayor of Toronto; and Councilor for Ward 1, Etobicoke North, and his staff for their assistance during this research.

My most heartfelt thanks to my wife Lauren, and sons Royon, and Relon, for their patience, and support to me in helping me to stay on course to complete this task.

To every other person and organization who made it possible to accomplish this project I say thank you.

Above all, I give glory to God for helping me to stay on the journey. 


\section{CHAPTER 1}

\section{INTRODUCTION}

Chapter 1 describes the background and purpose of the study with attention to the characteristics of the Toronto West Seventh-day Adventist Church, including its location and the community it serves. This chapter includes the statement of the problem, the justification for this dissertation, the expectations, an overview of the dissertation project involving this church and the community it serves, limitations, and definitions of terms.

\section{Background to the Problem}

\section{History of Toronto West Seventh-day Adventist Church}

Toronto West Seventh-day Adventist Church has been called by Adams (2000) the "Mother of Churches” (p. 39). It has been influential in establishing 13 other churches in the Greater Toronto Area. The church was founded on December 14, 1963, and is located at 1621 Albion Road, Etobicoke, Toronto, Ontario, Canada. It ministers to people who live in one of the world's most diverse cities, with King, Hracs, Densteldt and Bednar (2010) noting that "the city of Toronto is home to individuals from 216 ethnicities” (p. 4). The population of Toronto is currently “2.79 million” (DiversityToronto facts, n. d., para. 1), and the population of Ward 1 Etobicoke North, where the church is located, has a population of 60,300 (City of Toronto, 2008, p. 1).

The church building is located on 2.29 acres of property with a total square 
footage of 40,000. The building consists of the following: the sanctuary, five administrative offices, gymnasium/social hall, senior's room, community services room, six classrooms, prayer room, treasury room, mother's room, three store rooms, and a kitchen. In 2012 when the project was started, the church had a membership of 1,306 (Linrud, 2013, p. 139) with a Sabbath attendance of approximately 1000 persons. The total number of participants in all programs is approximately 1050, including visitors. Toronto West Seventh-day Adventist Church is affiliated with the Ontario Conference of Seventh-day Adventist and supports the following educational institutions: (a) Burman University (b) Crawford Adventist Academy, (c) Peel Seventh-day Adventist School, and (d) Crawford East Adventist School.

Adams (2000) noted that the history of Toronto West Seventh-day Adventist Church is that of "vision, sacrifice and courage" (p. 39). The history began in the 1950s when many immigrants from the Caribbean began migrating to Canada in search of work and new opportunities. Many of those migrating to the city of Toronto and its environs were Seventh-day Adventists, and some of them became members of the Pauline Street Seventh-day Adventist Church. These migrants were accustomed to being active in their Caribbean home churches and they anticipated that this would be the same in Canada; however, they found that the evangelistic vibrancy of the Pauline Street Church was different. After much discussion about the cultural differences in the approaches to evangelism by the West Indian Seventh-day Adventists, a group of eight who had a desire for fostering evangelism decided to start a church. This select group of members decided to invite approximately 100 persons to a Sabbath service at 460 Shaw Street in Toronto on December 16, 1961, and from this service a church company was established. 
This company began renting a British Methodist Episcopal Church building; two years later, on December 14, 1963, the company was organized into the West Toronto-day Adventist Church, the first Black Seventh-day Adventist Church in Canada. It should be noted that "though many in the Toronto-West Indian Adventist community initially saw it otherwise, the aim of the group was never that of establishing a Black church” (Adams, 2000, p. 39). Rather, they found the local church quite inactive and their goal became to be a missionary church, "a church willing to take the gospel to the neighborhood, a church that would respond to the needs of the community” (Adams, 2000, p. 39).

The church relocated in 1999 to the Etobicoke North Area of Toronto. The main reason for this was to pursue its original vision of being a Missionary Church that responded to the needs of the community. I arrived at this church on January 4, 2006, and was determined to assist the church in carrying out its mission. The mission statement of Toronto West Seventh-day Adventist Church states,

The Toronto West Seventh-day Adventist Church, through God's grace will spread the good news of salvation to mankind, and live in harmony with His commandments, while fulfilling the spiritual and social needs of its congregation and surrounding community. (Mission, Toronto West Seventh-day Adventist Church, n.d.)

To accomplish the part of the mission statement that related to fulfilling the needs of the surrounding community, the church had tried to reach the community through its Community Services Department, which offered a number of programs geared towards the community. However, the programs were not well attended by members of the community. It was apparent that the programs did not seem to be able to reach the intended target group, since many members of the church and very few people from the community were attending the programs. 


\section{Current Context of the Church}

In order to ascertain why the attendance of people from the community to the programs of the Community Services Department was not good, I observed that the church is located in Ward 1, of the Etobicoke North District within the City of Toronto. This district includes the West Humber Claireville Neighborhood, and The Mount OliveSilverstone-Jamestown Neighborhood. In 2006, Etobicoke North had a total population of 60,300 (City of Toronto, 2008), with 60.3\% between the ages of 20 and 64. The top ten ethnic origin groups in Ward 1 were (a) East Indian, (b) Jamaican, (c) Italian, (d) Canadian, (e) Southern Asian, not included elsewhere (n.i.e), (f) Filipino, (g) Sri Lankan, (h) Pakistani, (I) Chinese, and (j) Guyanese (City of Toronto, 2008, p. 3). It is quite evident that the church had relocated to a multi-ethnic neighborhood.

On further observation, I noticed that the neighborhood was undergoing a demographic transition: $79.2 \%$ of the population of Ward 1 were first generation immigrants, and over a five years period, $46.3 \%$ of the population were considered movers immigrants (City of Toronto, 2008, p. 4). Between 1996 and 2001, 42.6\% of the migrants to Ward 1 were from Southern Asia, including India (City of Toronto, 2003, p. 4). This category of migrants increased further for the period 2001 and 2006 in Ward 1 where 59.5\% came from Southern Asia (City of Toronto, 2008, p. 5).

The city of Toronto website, in its category of 2011 neighborhood estimates, indicated that the two city neighborhoods which comprise Ward 1 of Etobicoke North had a high percentage of “visible minorities.” Visible minorities in Canada are people who are considered non-Caucasian or non-Aboriginal people (“Statistics Canada,” 2012, para. 1). The Mount Olive-Silverstone-Jamestown neighborhood has $86 \%$ visible 
minorities (City of Toronto, 2014, p. 4), and the West Humber-Claireville neighborhood had 79 \% visible minorities (City of Toronto, 2014, p. 4).

Seim (2013) noted that from 1987 to 2011, 50\% of the migration to Canada moved to Toronto. Thus the community is a multi-ethnic, multi-cultural immigrant community that is constantly changing. According to Claerbaut (2005), an urban area like Ward 1 can be designated as a "transitory neighborhood" because there is a visible population change and the community is divided into clusters (p. 76). Claerbaut (2005) further noted that "urban pastors need to classify the neighborhood in which the church is located, discover the needs of the community, and develop strategies for action” (p. 77). It must be noted that there needs to be a systematic study to come up with specific strategies to meet the varied multiethnic groups as a church successfully. Claerbaut (2005) stated that the strategies for action developed by urban pastors must be focused on establishing "bridges” between the church and community (p. 77).

\section{Comparison of Church and Community}

The demographics of the community indicated that $25 \%$ of the total population is of Southern Asia origin, with the largest people group coming from India; however only $0.2 \%$ of the church membership reflects this origin, which is the smallest people group in the church. The Caribbean and Bermudan community population of Ward 1, is $8.1 \%$, but this population accounted for $75 \%$ of church membership. In regards to language usage, approximately 58\% of the population of the community claims that English is not their

mother tongue; however, $97 \%$ of the church membership claims English as their mother tongue. The data clearly indicated that a number of demographic characteristics of the community where the church is located are not reflected in the membership. Thus there 
are significant observed differences between the church and the community (City of Toronto, 2008).

\section{The Problem}

Toronto West Seventh-day Adventist Church is a large Seventh-day Adventist Church which has a membership of 1,306, located in a very diverse urban community of Etobicoke North in Toronto, with great variation in ethnicity, language, culture and religion. In the church's neighbourhood, there is a predominately growing immigrant population that is currently in flux due to the demographic transition. This poses a number of challenges for this church because there are so many varying ethic and cultural groups that makes ministering to this community very difficult. The church has tried to reach its neighbours by hosting community services events such as a free mid-week community supper and an annual thanksgiving dinner; however, many of the community services events are not well attended by people from the community.

In examining the number of baptisms to date, it can be noted that 299 persons were added to the church from 2000 to 2011, but almost all the baptisms came from family members and friends of family members in the church. It must be emphasized that since the church was relocated to this community in Etobicoke in 1999, no members from the community belonging to the largest ethnic groups (East Indian, Filipino, Chinese, Sri Lankan, Pakistani, Italian, and Southern Asian n.i.e) have joined the church to date. These findings certainly indicate that the best efforts of the church to date have not resulted in individuals from the community who are not of West Indian ethnicity becoming members. There definitely seems to be a total disconnect between the church 
and the community since members from the community are not attending programs sponsored for them and they are not becoming members in the church.

\section{Purpose of the Project}

The purpose of this project is to develop and implement a strategic marketing plan for community ministries for the Toronto West Seventh-day Adventist Church in the Etobicoke North area of the city of Toronto. The strategic marketing plan was evaluated by comparing the attendance of visitors from the community to an initial communitybased program as sponsored by the community service department prior to the marketing plan and again after implementation of the marketing plan. The marketing plan was assessed in the area of promotion to determine the effectiveness of the different types of promotion, with the goal of assessing the most effective types of promotion used in the implementation of the plan so that these can be used in future promotions of programs for this community.

\section{Justification for This Project}

1. The mission of the Toronto West Seventh-day Adventist Church involves reaching all of humanity in Etobicoke North with the gospel. The process of strategic market planning provides a model for accomplishing this mission via the Community Services Department of the church. The model may also assist the church in developing a better understanding of the population they are currently serving, thus allowing them to plan programs to meet the needs of the individuals in the community. The goal is to improve the relationship between the church and the community that will certainly allow the community to have a better understanding of the church serving their community. 
2. There seems to be no established Seventh-day Adventist model for strategic market planning in large churches to deliver community services to their communities. The leadership has struggled with the planning, especially with the community demographics as confronted by Toronto West Seventh-day Adventist Church. In investigating this current phenomenon, a model can be realized so that churches like this one can discover new and improved ways to minister to its neighbourhood.

3. The church would be able to allocate its resources more effectively, and training for ministry in churches located in communities such as where Toronto West Seventh-day Adventist Church is located can be more focused and chances for building success bridges would be greatly enhanced.

\section{Overview of the Project}

The purpose of Chapter 2 is to explore the biblical and theological foundations for community services. This is done to provide a theological foundation for serving the needy in the neighbourhood of the church. The theological exploration will be done on the mission of God, his people, and his church in the Old and New Testament to the socioeconomically disadvantaged. The writings of Ellen G. White will also be examined to get any guidance as it relates to community services to the needy.

Chapter 3 addresses the literature relating to works published about strategic marketing planning between 2000 and 2013 for businesses and churches. Although this is not an exhaustive review of literature on the subject, four aspects of strategic market planning that are critical to this project are reviewed: (a) definitions of marketing, strategic marketing, and strategic market planning, (b) the strategic marketing planning 
process-an overview, (c) marketing for churches, and (d) strategic marketing for churches.

Chapter 4 describes the methodology of the development and implementation of the strategic marketing plan for the Toronto West Seventh-day Adventist Church. Three aspects of the strategic planning process will be described and discussed in detail: (a) the analysis of the situation, (b) the development of the marketing strategy, and (c) the implementation and control of the strategy.

Chapter 5 highlights the results of the development and implementation of the strategic marketing plan at the Toronto West Seventh-day Adventist Church and will also focus on the results of the situation analysis, the development of the strategy, and the implementation and control of the plan.

Chapter 6 will present the summary of the overall findings of this project with the goal of defining an effective model of strategic marketing for the Community Services Department at Toronto West Seventh-day Adventist Church to build bridges between this church and the community it seeks to serve. Conclusions and recommendations will be made based on the results of this project that will help this church develop provide further strategies for future success. Recommendations for future studies will be presented as well. Also, how I have grown as minister from this project.

\section{Expectations for This Project}

The following are the expectations of this dissertation:

1. This project will increase the knowledge and capacity of the members of the Toronto West Seventh-day Adventist Church to minister to the Etobicoke North Community. 
2. It will provide a strategic market-planning model for reaching the community.

3. It will help in the growth and development of urban ministry leaders in the congregation.

4. It will provide a strategic marketing planning model that can be used by other pastors and congregations with similar characteristics of Toronto West Seventh-day Adventist Church so they can be successful in their ministries to the communities they serve.

\section{Limitations of This Project}

This project is a qualitative study about developing and implementing a strategic marketing plan for community ministries at the Toronto West Seventh-day Adventist Church. Qualitative research is used to examine and understand how and why things are the way they are specific to this church and the community it serves (Gay, Mills, \& Airasian, 2012). Some of the know-hows of the Toronto West Seventh-day Adventist Church can be replicated by other churches faced with challenges similar to those of this church. It must also be stated that anyone trying to replicate this experience must take into account that each church is unique in its membership, structure, and location; thus, careful study must be done in terms of the feasibility in comparing the findings of this project before adapting the model presented in here.

\section{Definition of Terms}

The following are definitions of certain words and terms used in this project document: 
Marketing. "The activity, set of institutions, and processes for creating, communicating, delivering and exchanging offerings that have value for customers, clients, partners and society at large” (“Definitions of Marketing,” 2007, para. 1).

According to Brennan, Baines, Garneau, and Vos (2008), strategic marketing is concerned with identifying changes in the market and the business environment, and then ensuring that the firm is well prepared to meet them. It involves looking beyond the day-to-day marketing battleground, reflecting upon the key changes that lie ahead and deciding how the firm will respond. (p. 13)

Needs. States of physical or mental deprivation can be functional, psychological, or social (Sandhusen, 2008, p. 3).

Real Needs. The actual needs of the customers (Kotler \& Keller, 2006)

Felt Needs. "A basic concept in community development and one of the key concepts of community development. Felt needs are changes deemed necessary by people to correct the deficiencies they perceive in their community" (Onyenemezu \& Olumati, 2013, p. 156).

Need identification. A process of identifying health and social service requirements in a geographic and social arena (Alston \& Bowles, 2003, p. 124).

Needs analysis. A process of prioritizing identified needs (Alston \& Bowles, 2003, p. 124). 


\section{CHAPTER 2}

\section{BIBLICAL/THEOLOGICAL FOUNDATIONS}

\section{INTRODUCTION}

This chapter is an exploration of the biblical and theological foundation for community ministries. It seeks to construct a biblical theology, which serves as the theological foundation for this project. It posits that a theology of community ministries finds its source in God, and his mission to redeem his children. True theology, the study of God's nature, characteristics, capabilities, and disclosures, is rooted in the Bible (Slick, n.d., para. 1). According to Grenz and Olson (1992), theology utilizes three reference points, the gospel as found in the Bible, the legacy of the church, and the thought forms of current civilization to address matters of successive generations (p. 9). Sahlin et al. (1994) saw the purpose of community ministries as serving the poor and brokenhearted in the name of Jesus (p. 13). As a result, my perspective in this research is that a theology of community ministries is a study of the nature and character of God as it relates to serving the poor and broken-hearted in Jesus' name. This theology takes into account the gospel as found in the Bible, the legacy of the church of the Old and New Testament, and the thought forms of contemporary society. It is based on the biblical certainty that God is loving and compassionate, and that he expects all peoples to love their neighbors as themselves.

The Bible declares that "God is love” (1 John 4:8 KJV) and that "God is good” 
(Ps 136:1). It also portrays God as relational, because the word Elohim presupposes a plurality of beings (“Ministerial Association,” 1988, pp. 22-24). Consistent with this portrayal of God is the creation narrative of Genesis 1 and 2, in which a good God is shown creating a good world. As the crowning act of creation, God created man in his image and likeness and gave him dominion over the earth (Gen 1:26). Hamilton (1982) suggested that to be made in the image of God means man is both "representative" and “representational” of God (p. 27). Man was created to emulate God (“Ministerial Association,” 1988, p. 86).

Since God is declared to be "good” and “love,” and man was made in God’s image, it can be concluded that man was made to be good and to love. Thus, man was made a moral being with the capacity to relate to God and the rest of creation. The Bible also shows that man was created to be a member of God's family. "Have we not all one father? Hath not one God created us?” (Mal 2:10). Therefore, the creation of man initiated the fatherhood of God, and a brotherhood and sisterhood for the human race. These vertical and horizontal relationships are predicated on love (Deut 6:5; Lev 19:18b).

Unfortunately, man’s capacity to be able to have a wholesome relationship with God and his fellow human beings was damaged by the fall (Gen 3:1-24). Genesis 3:8-13 paints a picture of Adam and Eve being afraid, ashamed, naked, hiding from God, and not taking responsibility for the first sin. It also shows God on a mission to rescue and restore mankind (Gen 3:15, 21). This mission was announced in Genesis 3:15 and biblical scholars call it the protoevangelium (the first good news, or gospel), the mission announced by a loving God.

Bosch (as cited in Guder, 1998) noted that the mission can be comprehended as 
originating from the kind of person God is (p. 5). In addition to the Bible's declaration that "God is love" (1 John 4:8), God is described as a person of mercy, compassion, graciousness, righteousness, and justice. "Be ye therefore merciful as your father in heaven is merciful” (Luke 6:36). "The Lord is gracious and righteous. Our God is full of compassion” (Ps 116:5). “He rises to show you compassion,' exclaims the prophet Isaiah, because, ‘the Lord is a God of justice’ (Isa 30:18)” (Sahlin et al., 1994, p. 7). This nature of love and his attributes of mercy, compassion, graciousness, and justice serve as the basis for his mission to redeem all people.

John tells us that in performing this mission, Jesus was sent because of God's love. "For God so loved the world, that he gave his only begotten Son, that whosoever believeth in him should not perish, but have everlasting life” (John 3:16). Likewise, Peter states that God does not desire that anyone should perish (2 Pet 3:9). Thus, God cares about the salvation of the entire human family. This worldwide care includes the welfare of the poor, orphans, widows, and aliens who are referred to in this chapter as the needy.

In exploring the biblical and theological foundations for community services, the mission of God, his people, and his church to the needy is examined. The chapter includes definitions, key terms, and the biblical foundations of the Old Testament and New Testament regarding ministering to the needy, and a possible theology of community ministries for the Toronto West Seventh-day Adventist Church. Due to the nature of this research, it is not an exhaustive study.

\section{Definitions}

In this project, the term "socioeconomically disadvantaged" is used to include the poor, widows, orphans, distressed, and aliens. The Library of New South Wales (2014) 
notes in its definition of the term socioeconomically disadvantaged that it refers to people who find it difficult to provide the normal necessities of life such as food, clothing, and shelter for their families. This may include seniors, single parents, the sick, people who are physically challenged, the unemployed, and the homeless ("State Library of New South Wales,” 2014, para. 1). Webster (2006) defines the poor as "having no money, needy; deserving pity unfortunate...those who have little”(p. 216). Achtemeier (1985a) defines the poor as "lacking in material or spiritual goods" (p. 807). In the same dictionary he includes the following statement about the biblical view of the poor:

The view of the poor is revealed in the chief Hebrew terms for the poor, which address them as needy, without power, and abused by those with greater power. Leviticus defines the poor as those who are lowly because their power [lit., hand] wavers, (25.35 or is insufficient (14:21).They do not have the capacity to provide for themselves the essentials of life. Their deficiency in life supporting is understood to exist in relation to the rest of the community, represented by the phrase 'with you, repeated twice in 25.35(cf 'beside you' in v. 36); that is their crisis is based in the network of power relationships that form society. (1985a, p. 807)

Thus the poor are those who find it difficult to provide for themselves financially.

Harper's Bible Dictionary defines the word "widow" as "a woman whose husband has died.” The dictionary also mentions, "the status of the widow in ancient Israelite society was precarious. Having no inheritance rights and often in want of life's necessities, she was exposed to harsh treatment and exploitation” (Achtemeier, 1985d, p. 1,132). In addition, The Theological Dictionary of the New Testament states that the common Greek usage of 'this word, 'widow,' derives from a root meaning 'forsaken,' and it may thus refer to any woman living without a husband” (p. 1313). It also states, in reference to this word as used in the Old Testament, that

widows are associated with others who are disadvantaged, e.g., orphans, aliens, or day laborers. They suffer wrongs (Is. 10:2) or loss of rights (1:23). They are held in low esteem (54:4); cf. their special clothes (Gen. 38:14). Like harlots or divorcées, 
they may not marry the high priest (Lev. 21:14), or, in the program of Ezek. 44:22, any priest at all unless they are the widows of priests. (p. 1,313)

Another class of the socioeconomically disadvantaged is orphans. The Theological Dictionary of the New Testament states, "This word means "bereaved," “without parents or children,” "orphaned,” "orphan.” In the Septuagint (LXX), it is usually associated with "widow” (Isa 1:17). Occasionally it has the figurative sense of “abandoned," "deprived” (p. 734).

In writing about orphans, Hughes (2008) stated that "the Old Testament orphan (yatom) was not necessarily a child that had lost both parents. The primary meaning of (yatom) is fatherless” (p. 71). Thus children who lived with a widow would be considered orphans.

The final category of needy persons was the stranger or alien. In the Old Testament, according to Easton’s Bible Dictionary, the word "alien” means “a foreigner, or person born in another country, and therefore not entitled to the rights and privileges of the country where he resides"' (Easton, 1996, p. 1,897). In addition, it mentioned that there were two classes: "those who were strangers generally and who owned no land or property and strangers dwelling in another country without being naturalized” (p. 1,897). Harper's Bible Dictionary also translates the word “stranger” as “('sojourner' or 'alien' in some translations), in the Bible one who is not a member of a particular social group” (Achtemeier, 1985c, p. 995). It stated, "after the settlement in Canaan, the term not only designated a temporary guest but also acquired the more specialized mean of a resident alien who lived permanently within Israel” (p. 995).

In writing about vulnerable groups in Israel, Hughes (2008) noted that there were two types of people designated as aliens in Israel. First, there was the class called ger or 
plural, gerim in the Hebrew. These included people like Rahab and the Gibeonites, as well as those who migrated to Israel, people who were well disposed to the culture and customs of Israel (Hughes, 2008, p. 720). These people were not Jews. Second, there were the nokri. These were foreigners who insisted on clinging to their own gods and customs. According to Hughes (2008), it was the gerim who were to be encouraged and treated well by the Jews because they had moved closer to God. It is this group that is classified as vulnerable and deserving of good treatment (p. 72). It should be noted that not all aliens in Israel could be considered socioeconomically disadvantaged.

In the $21^{\text {st }}$ century, many countries give the designation of "immigrants" to those who would have been classified as "resident aliens” in the Old Testament. In the New Testament, the words “alien” and "stranger” have a different connotation. According to Easton, “alien is used (Eph. 2:12) to denote persons who have no interest in Christ” (p. 1,897). Achtemeier (1985c) stated “in the NT 'stranger' usually means simply someone who is not known (Matt. 25:34-40; John 10:5) or, in some older translations, a foreigner (Luke 17:18; Acts 17:21).”

\section{Key Terms}

God is love. Grudem (1994) interpreted God’s love as meaning that “God is eternally self giving” (p. 199). He observed, "this attribute of God shows that it is part of his nature to give of himself in order to bring about blessing or good to others” (p. 199).

God is also merciful and compassionate. Watkins (1994) observed, “in Hebrew three words are translated mercy: hesed, which is means kindness; raham, which refers to bowels, and hanan, which is also translated gracious” (p. 50). Harper's Bible Dictionary stated that the 
Hebrew uses several words for 'mercy,' of which the most frequent is hesed, which means loving-kindness, mercy, love, loyalty, and faithfulness. Another Hebrew word and the Greek word for mercy in the NT refer to the emotion aroused by contact with undeserved suffering, that is, compassion and a deeply felt love for a fellow human being. (Achtemeier, 1985a, p. 626)

God's nature of love and the attributes of mercy and justice determine how he relates to the needy, expects all peoples to relate to them, and provides a basis for the theological foundations of Community Ministries.

\section{Old Testament Foundations}

Paul notes in Romans 15:4, "For whatsoever things were written aforetime were written for our learning.” Therefore, we can learn principles from the Old Testament about ministering to the socioeconomically disadvantaged which may be applicable to our time. The Old Testament has two sets of information about God's care for the socioeconomically disadvantaged. The first set is about people outside of Israel such as Job and the inhabitants of the city Sodom. This information is very limited. The second set is about God's instruction to Israel about the socioeconomically disadvantaged within its borders.

The Mission of People Outside of Israel

The Old Testament book of Job portrays its main character, “Job,” as a person of integrity, uprightness, someone who fears God and shuns evil (1:1). Davidson (2001) mentioned that Job is a dedicated believer who is not of the Abrahamic covenant line and the book, which is written about him, is considered the oldest book of the Bible (p. 137). To Nichol (1980d), Job could have lived at the same time that Moses live in the land of Midian. In the book, God upholds Job as an emblem of blamelessness (Hebrew, tam). 
Oliver (as cited in Caesar, 2000) defined tam as meaning "complete, blameless, just, honest, peaceful, perfect and beautiful, an attitude that reflects genuineness and reliability” (pp. 149, 150). Within the context of Job’s blamelessness, it is mentioned that he helped the poor. "Whoever heard me spoke well of me, and those who saw me commended me because I rescued the poor who cried for help, and the fatherless who had none to assist them” (Job 29:11, 12). "The one who was dying blessed me; I made the widow’s heart sing” (Job 29:13). "I was eyes to the blind and feet to the lame. I was a father to the needy: I took up the case of the stranger. I broke the fangs of the wicked and snatched the victims from their teeth” (Job 29:15-17). In commenting on this text, Keil and Delitzsch (1996) noted that Job’s philosophy necessitated holding on to the will of God, which above all requires sympathizing love (p. 558). To be blameless like Job means a purposeful dedication to virtuousness (Caesar, 2000). Job’s dedication to goodness is noted several times as pleasing to God (Job 1:8; 2:3; 42:7-9).

While Job is upheld as a person who is blameless, the inhabitants of the city of Sodom are not held up a blameless. Like Job, they are not of the Abrahamic covenant line. They lived at the same time as Abraham and are destroyed because of their sins. In writing about their sins, the prophet Ezekiel states, "Now this was the sin of your sister Sodom: She and her daughters were arrogant, overfed and unconcerned; they did not help the poor and needy" (Ezek 16:49). This statement shows that God considered it a sin for the people of Sodom not to be concerned about the welfare of the poor and needy. While Job took care of the poor and needy, Sodom did not. From these two passages, it could be seen that God expects even people who are outside the church to take care of the socioeconomically disadvantaged. Since man is made in the image of God, he is expected 
to represent God. It is a sin to misrepresent God as someone who does not care for the socioeconomically disadvantaged because it is violation of the truth that "God is love" (1 John 4:8). Job’s mission included representing God to his neighbours.

The Mission of People Inside of Israel

The Old Testament also shows God's compassion for the disadvantaged in many of the instructions given to Israel. These instructions were primarily for people within the commonwealth of Israel. The people within the commonwealth of Israel knew that God expected them to love their neighbours as themselves (Lev 19:18b). They had been chosen to know him, to understand him and to be his witnesses, (Isa 40:10). Thus, a study about how God expected them to relate to the socioeconomically disadvantaged may provide principles that can be applied to how we relate to such people. In addition, it can help us to understand the legacy of the church's ministry to the socioeconomically disadvantaged.

In Genesis, as an expression of this goodness and his intention to save man, God called Abraham. He promised to bless him and informed him that he would be a blessing to all nations (Gen 12:1-3). Through this call, Abraham was enlisted in the mission of God. Inclusion in the mission meant a bestowal of blessings from God upon Abraham. These promised blessings were to be inherited by Israel (Gen 26:4). Thus, the mission of Israel included special blessings from God. These blessing would have made them prosperous, happy, and economically the number one nation in the world (Deut 11:8-12). Through this preeminent position of being the number one nation, all other nations would have enquired about God. Thus, Vyhmeister (1990, para. 13) observed: 
the Old Testament model of mission centered on a people whose well being would attract the attention of all who observed them. Israel was to have been prosperous and holy, blessed, and happy. Its neighbours would ask" For what great nation is there that has a god so near to it as is the Lord our God whenever we call on Him? (Deut. 4:7).

Israel's wellbeing was indicative of God blessings.

In order to receive this prosperity and happiness, Israel had to live a lifestyle that was consistent with the nature and mission of God. This mission included following the God-given instructions and prophetic reminders to care for the socioeconomically disadvantaged in Israel. Hoppe (2004) saw a connection between the blessing God gave to Israel and their care for the socioeconomically disadvantaged. Nichol (1980c) mentioned that Judah's deficiency in not caring for the poor was a contribution factor to the destruction of Jerusalem (Jer 22: 3-5). Thus, Moskala (2008) concluded that mission is about modeling the principles of the God given message. For Israel, this modeling included following divine instructions for protecting and providing for the socioeconomically disadvantaged.

These instructions were given in different forms. First, there were laws, which were given to protect and provide for the socially underprivileged. Second, there were prophetic reminders to take care of the socioeconomically disadvantaged. Among the laws was, the release of the land every seventh year, the prohibition of interest, and the jubilee.

\section{The Law of the Seventh-Year Release}

There are several references to the law of release of the land in the seventh year. It is mentioned in Exodos 23:11; Leviticus 25:1-7; and Deuteronomy 15:2-18. A 
comparison of these three passages reveals that God intends that the socioeconomically disadvantaged in Israel were to be provided for in different ways. First, they could borrow from others to alleviate their circumstances. Deuteronomy 15:7, 8 indicates that God expected those who were capable in Israel to lend to those who were underprivileged. Second, through his providential care, God would provide food for them in the seventh year free of cost. During this seventh year, the produce of the land was to be eaten garden-fresh and the rest was to be given freely to the needy (E. G. White, 1890). In doing this, Israel would have given a picture of a compassionate God to the socioeconomically disadvantaged.

Third, the law required a cancellation of debts (Deut 15:1- 4). Fourth, slaves were to be set free (Deut 15:12 -15). In addition to being set free, their former owners were to provide them with food to take care of their needs. Fairbairn (as cited in Hughes, 2008) suggests that this law was opposed to selfishness. Hoppe (2004) saw this law as indicative of the actions of God towards the needy.

\section{The Law Prohibiting Interest}

Since circumstances may have led to situations where people who were socially underprivileged had to borrow, there was a law which prohibited the taking of interest. This law is stated in three passages: (Exod 22:25; Lev 25:35-38; Deut 23:19-20). Hughes (2008) explained this law as providing protection for the needy from exploitation. Nichol (1980c) saw this law as speaking against all forms of greed.

\section{The Jubilee}

Among the laws to protect the socially underprivileged in Israel was the law of 
the Jubilee. This law, found in Leviticus 25:8-54, is based upon the concept that the land belongs to God. Nichol's (1980e) observation about this law was that it was a reminder that God owned the land. Since God owned the land (Lev 25: 23), Hughes (2008) noted that in the jubilee year, God took back possession of the land and redistributed it impartially. God did this by giving the Israelites a law which stipulated that every fiftieth year, slaves were to be set free, and land which had been sold by its original possessors because of unfortunate circumstances was to revert back to its original owners. This was to be done if the holders or relatives of the owners had not redeemed it. Hoppe (2004) saw the Jubilee as a reminder to Israel of their responsibility to take care of the poor. In addition to serving as a reminder of caring for the poor, the jubilee laws ensured that the slaves who were set free got the opportunity to be free from excessive labor. They were to rest for a year. E. G. White (1890) stated that the people were able to rest and regain their health. Barker (2009) indicated that the laws of the Jubilee made provision for securing housing and work for everyone (p. 55). In addition, families that had been torn apart due to unfavorable economic circumstances would be given a year to be reunited. They would also have the time to heal emotionally from the trauma of separation. The laws of Jubilee year show that God is concerned that each person should have a home. It also demonstrates that he is concerned about the restoration of families and people’s possession.

Hoppe (2004) showed that the intention of the Jubilee was the restoration of economic balance in the Jewish society and a restoration of people's relationship with God. This could be accomplished because the land could not be sold permanently (Nichol 1980e, p. 811). Moreover, the law specified how the land could be sold and how it could 
be redeemed. The land could be sold only under conditions of poverty. E. G. White (1890) indicated that the owner could only sell due to poverty and the seller or his relatives could redeem the land at any time (p. 534). In addition, the price could not be set to oppress one another whether in buying or selling. Therefore, the Jubilee made it impossible to use land as a means of exploiting the poor. Land in Israel could not be bought at a low price and then resold at an exorbitant price (Hughes, 2008, p. 68). This suggests that God is against the exploitation of the poor and desires that adequate provisions be made for them through the legislation of the land. This legacy means that the church should speak up against the exploitation of the poor wherever it is possible. The church should also try to influence the legislation of the land to ensure that provision be made for families who are poor. Thus, one foundation for a theology of community ministries should include advocacy for the poor and justice ministries for the enslaved.

The law also specified how the price of the land was to be calculated and how the land could be redeemed. The price depended on the number of harvests left to the year of Jubilee. Carson, France, Motyer, and Wenham (1994) stated, "Since the land could not be sold, technically what was being sold was the harvest from the land or the use that was made of the land.” He also noted that “an approaching jubilee diminished the cost for the purchaser, inasmuch as he was buying the number of harvests until the jubilee restored the land to its original owner” (Carson et al., 1994, p. 153).

Thus, the jubilee, the law of the seventh year release, and the law prohibiting the taking of interest, were given to Israel by God to protect and to provide for the socioeconomically disadvantaged. If Israel obeyed these laws they would be blessed and be a happy people. In so doing, they were partially fulfilling the mission of God to 
redeem his children who were socioeconomically disadvantaged.

In addition to the previously mentioned regulations that were designed to help the socioeconomically disadvantaged, there were other stipulations that had been given to Israel in the area of their mission to the needy. Among these were the stipulation about gleaning, use of the tithe in the third year, and prompt payment of wages.

\section{The Law of Gleaning}

The law of gleaning is found in Leviticus 19:9-10; 23:22 and Deuteronomy 24:1722. It stipulated that during the harvest, the owners of farms should not harvest the entire crop, but leave behind some for those who were socioeconomically disadvantaged. They were to be allowed into the fields to gather freely what was left from the harvest. This stipulation was given to ensure that there was a provision of food for the socioeconomically disadvantaged and to protect their self-esteem. Hughes (2008) observed that the passage in Deuteronomy that contains these provisions is about the very poor (p. 67). In addition, Hoppe (2004) showed this law made provision for both food, and work for the poor. In so doing, it helped to maintain their self-esteem. It is this law that made it possible for Ruth, a non-Jew, to glean in the fields of Boaz (Ruth 2:1-8). This law shows that God demonstrated his compassion for those who were socioeconomically disadvantaged by stipulating that food and labor be provided for them.

\section{The Use of the Tithe in the Third Year}

The commandment about the use of the tithe in the third year is found in Deut 14:26-29. It indicates that in the third year, a portion of the tithe could be used to feed the socioeconomically disadvantaged. Nichol (1980b, p. 1,003) thought that this stipulation 
meant that the second tithe could be used to feed the poor and aliens. E. G. White (1952) discussed that the second tithe could be used every third year to provide food and amusement for the poor. Thus, the mission of Israel included setting aside a specific portion of the individual's income- - one tenth — in the third year to minister to the socioeconomically disadvantaged.

\section{The Payment of Wages}

Included in the ministry of Israel were issues of justice such as payment of wages on time to the socioeconomically disadvantaged. The legislation that addressed this matter is found in Deuteronomy 24:14-15 and Leviticus 19:13. It specifies that the socioeconomically disadvantaged were to be paid at the end of the day before sunset. This stipulation also indicated that it was a sin to withhold the wages. This was to ensure that the person and his family would not suffer undue hardship. Hoppe (2004) discussed that the result of not paying these wages would mean that the person could not buy food for the next day. Such a law made it illegal to hold back a person’s salary.

\section{The Reminders and Warnings of the Prophets}

Israel was granted the opportunity to be partakers in the mission of God through ministering to the needy amongst them. Unfortunately they did not always follow divine instructions. Consequently, God called his servants the prophets to remind them of their need to obey (Jer 7:25). Thus, within the writings of the prophets, can be found reminders and warnings about ministering to the needy. In this section, some of the prophetic reminders and warnings to Israel about their ministry to the needy will be examined.

Amongst the major reminders and warnings are those of the prophets Amos and 
Isaiah. Amos ministered “between 767 and 753 BCE” (Nichol, 1980a, p. 954). During this time period, the twin nations of Israel and Judah under the kingship of Uzziah and Jeroboam II respectively were very prosperous. In their prosperity, they departed from caring for the socioeconomically disadvantaged. Consequently, God raised up the prophet Amos. Amos reproved the wealthy for their oppression and exploitation of the poor (Nichol, 1980a).Thus, in Amos 2:6-8; 4:1-2; and 8:4-8, major warnings are mentioned about the judgment that would be meted out to Israel as a result of their oppressing the needy.

Another prophet who reminded Israel about their responsibility to the socioeconomically disadvantaged was Isaiah. His ministry spanned the years 739 to 686 BCE. Like Amos, Isaiah lived at time when justice was perverted and the rich deliberately oppressed the poor. Thus, he stated, "Learn to do well; seek judgment, relieve the oppressed, judge the fatherless, plead for the widow" (Isa 1:17).

The Old Testament shows God's concern for the socioeconomically disadvantaged both inside and outside the church. Outside the church, Job’s character is held up as a model of what God considers a perfect person to be. Caesar (2000) saw Job’s character as a paradigm of the people who will be living in the time of the escathon (p. 159). Job's perfect character included helping those who are poor and needy. Outside the church, Sodom was destroyed because it did not help the poor. As a model society, Israel was instructed and warned about protecting and making provision for the socioeconomically disadvantaged. If Israel had followed these instructions, they would have being the recipients of the promised blessings of prosperity and happiness. They 
would also have served as a beacon of how God wanted life to be and, in so doing, aid in the mission of God.

\section{New Testament Foundations}

The Mission of Jesus

The New Testament presents the greatest demonstration of God's care for all of mankind in the mission of Jesus. In announcing the mission, Jesus stated, "The Spirit of the Lord is upon me, because he hath anointed me to preach the gospel to the poor; he hath sent me to heal the brokenhearted, to preach deliverance to the captives, and recovering of sight to the blind, to set at liberty them that are bruised, to preach the acceptable year of the Lord” (Luke 4:18, 19). He also said, "I am come that they might have life, and that they might have it more abundantly” (John 10:10b). Thus, Jesus outlined a mission, which included caring for all peoples. This includes the needy.

The Old Testament includes references to four categories of the needy - the poor, widows, orphans, and aliens. However, in the New Testament, these four categories are not listed together. Instead, there are several references to the poor. The poor in some references may have included the four categories mentioned in the Old Testament. Capps (2009) stated, “in both Isaiah and Luke_Acts, “poor” is a broad term for many kinds of weakness, especially caused by uncontrollable circumstances (e.g., widowhood or blindness) or by unjust and oppressive treatment by others” (p. vii).

In his analysis of Luke 1 and 2, Capps (2009) stated that in fulfilment of the Old

Testament, Jesus came to deliver the needy (p. 6). He also mentioned that Jesus explained in Luke 4:43 that he had come to proclaim the good news of the kingdom to the poor. Following this announcement, the gospel of Luke makes a close connection between the 
kingdom of God and the poor (p. vi). The apostle John notes that Jesus said, "If you have seen me you have seen the father” (John 19:9e). Hence, in seeing Jesus working for and with the poor, we are seeing God's perspective on ministering to the poor and God's thoughts about the kingdom of God. We can also see a demonstration of his desire that all should have abundant life (John 10:10).

In announcing his mission in Luke 4:16-20, Jesus proclaimed that he had come to preach the good news to the poor. Commenting on this text, Richards and Richards (1987) stated that Jesus is quoting from Isa. 61:1-2 about the nature of his ministry. His ministry was to provide healing and good news for the needy. Nichol (1980f) noted that the love of Jesus for the poor was one of the most important proofs he used to confirm his Messiahship to the disciples of John the Baptist (Vol. 5, p. 728).

According to Luke (7:19-23), John the Baptist who was imprisoned by King Herod sent his disciples to Jesus to enquire about the authenticity of Jesus as Messiah. In his response, Jesus allowed the disciples of John to spend that day with him as observers. Then he instructed them to inform John what they had seen, "how that the blind see, the lame walk, the lepers are cleansed, the deaf hear, the dead are raised, to the poor the gospel is preached" (Luke 7:22c). Walvoord and Zuck (1983) noted that the healing actions of Jesus to the poor were used as evidence that he is the Messiah (p. 222). Capps (2009) saw that the association of Jesus with the poor was the one thing that he used to verify his answer to John that he was the Messiah (p. 20). Therefore, Jesus' ministry to the socioeconomically disadvantaged was a confirmation of his Messiahship. Moreover, Keltner (2012) suggested that Jesus showed his concern for the poor by spending time throughout his ministry with the socioeconomically disadvantaged (p. 1). This concern 
could be measured by the time he invested in alleviating their suffering.

\section{The Mission Beyond Israel}

Whereas, in the Old Testament, the mission of Israel focused on those who were in the commonwealth of Israel Jesus extended the mission of caring for the disadvantaged beyond Israel. Writing about the ministry of Jesus, E. G. White (1952) noted, “The Saviour mingled with men as one who desired their good. He showed His sympathy for them, ministered to their needs, and won their confidence. Then He bade them, 'Follow Me’” (p. 60). In Matthew 8:5-13, Jesus healed the centurion servant. In the passage Jesus stated that the he had not found faith in Israel like that of the centurion. Since the centurion was not a Jew in this miracle, Jesus extended help to people beyond the commonwealth of Israel. Moreover, in Matthew 15:21-28, Jesus healed a Syrophoenician woman’s daughter while on a journey outside Israel. In addition, Jesus taught about God's concern for the socioeconomically disadvantaged beyond Israel in such parables as that of the Good Samaritan (Luke 10:25-37) and "the sheep and the goats” (Matt 25:3146).

\section{The Story of the Good Samaritan- A Boundless Mission Paradigm}

One of the most enlightening stories about how people should relate to the socioeconomically disadvantaged is that of the Good Samaritan. The story is found in Luke 10:27-15. Nichol (1980f) believed the setting of story was the city of Jericho during the last journey of Jesus to Jerusalem (p. 782). E. G. White (1940) thought that there was great crowd who listened to this story (p. 497). 
In the story, a Jewish lawyer decided to test Jesus by asking him what should be done to inherit eternal life. Jesus answered the lawyer by asking him, "What is written in the law?” (Luke 10:26). To this question, the lawyer answered, "Thou shall love the Lord your God with all your heart and with all your soul and with all your strength and with all your mind, and your neighbor as yourself” (Luke 10:28). Upon hearing the lawyer's answer, Jesus said, "You have answered correctly; do this, and you will live” (Luke 10:29). In this answer to the lawyer, Jesus affirmed keeping the commandments "to love God, and one’s neighbors as oneself.” These commandments had been given to Israel during their wilderness journey (Deut 6:5; Lev 19:18b). Thus they were a part of the mission of Israel and the lawyer knew them.

Nichol (1980f) specified that loving in this way meant the complete dedication of a person's life to the service of God (p. 782). He also mentioned that the word "live" in Luke 10:28 means living life here and in the hereafter (p. 782). Consequently, Jesus asserted that living the godly life here involves loving people God's way and it is integral to having eternal life. This answer should have satisfied the lawyer. However, the lawyer sought to justify himself, and in so doing, asked the question, "And who is my neighbor?” (Luke 10:29). Levine (2014) interpreted this question as meaning that the lawyer was seeking to ascertain in a courteous way those who were not classified as his neighbors. To answer the lawyer's second question, Jesus told the story of a man who had been traveling from Jerusalem to Jericho. While on the journey, the man was attacked by robbers who wounded him, stripped him, and left him to die. In the story, a priest and then a Levite traveling along the same road encountered the wounded man, but instead of helping him, each passed by. Sometime after they had passed the wounded 
man, a Samaritan who was traveling on the same road encountered the wounded man. The Samaritan was moved with compassion for the wounded man. He stopped, poured oil and wine on the man's wounds, and bandaged his wounds. Then he placed the man on his donkey and took him to an inn. At the inn, he stayed for the rest of the day and took care of the wounded stranger. The next day, before he departed, the Samaritan gave the innkeeper a down payment to take care of the wounded man until he recovered. He informed the innkeeper that if the costs incurred in the man's recovery were more than what he had been paid, he would reimburse the rest when he returned. After telling the story, Jesus asked the lawyer, "So which of these three do you think was neighbor to him who fell amongst thieves?” (Luke 10:35). The lawyer answered the question by saying, "He who showed mercy on him” (Luke 10:36). Ellsworth (1976) noted that the enquiry of the lawyer was to determine the limits of his responsibility to his neighbor, but in answering the question, he stated that they are "none” (p. 59). Then Jesus said to him, “Go and do likewise” (Luke 10:37).

There are several salient thoughts in this story about the nature of helping the socioeconomically disadvantaged. Levine (2014) believed the Samaritan acted in the way God would have acted (p. 105). Therefore, in telling the lawyer to go and do likewise, Jesus was saying, Go, and do just as God would have done in a similar situation. Ellsworth (1976) concluded that the meaning of this story is that whenever one is confronted with a need he or she should act in a similar way to that of the Good Samaritan (p. 14). Acting in this way means acting with compassion towards the socioeconomically disadvantaged. To him this is also a story of limitless love (p. 20). In this story the function of the Good Samaritan is one of restoration (p. 55). Consequently, 
God's love is to be demonstrated universally to whoever is socioeconomically disadvantaged. Those who demonstrate such love should help in restoring those who are socioeconomically disadvantaged to a state of wellness. In this story, Jesus defines a neighbor as someone who is in need. In addition, genuine Christian love as seen in this story is concerned about the welfare of others and assists those who no one else wants to assist (p. 59).Thus Jesus presented a boundless mission paradigm in helping the needy.

The Mission of the Early Church

By including a ministry to the socioeconomically disadvantaged in his mission, Jesus demonstrated to his disciples that it was important. When Jesus sent out the seventy they went into the cities and towns of Israel and relieved the sufferings of many. This inclusion of ministry to the socioeconomically disadvantaged did not stop with the ascension of Jesus. Luke, in the book of Acts, recorded the favourable responses of the disciples to the needs of the socioeconomically disadvantaged. In this section, three incidents involving community ministries by the early church will be addressed.

\section{The Mission Inside the Church}

First, Acts 4:32-37 states that the believers lacked nothing because they had all things in common. Pfeiffer and Harrison (1962) stated that those who were rich sold their possessions so that the proceeds could be used to take care of the needy. In addition, they explained that the disciples distributed the proceeds from the sale based on the necessities of the believers (1962). 
Second, Luke, in Acts 6:1-6, stated that the church had experienced rapid growth and it engaged in a daily ministry to provide for widows. Thus, it can be seen that the church had developed some type of organised community ministries.

In addition, the church was becoming multi-cultural. There were Christians who spoke different languages, so the ministry was inclusive. However, as Pfeiffer and Harrison (1962) stated, a conflict developed over the distribution of food (S. Ac.6:7). The Grecian widows contended that the Hebrew widows were being more favoured in the distribution. The responses of the disciples to this contention suggest that there was a structure to the distribution of food. This ministry was accomplished through the use of tables. Walvoord and Zuck (1983) mentioned that the tables could refer to actual tables or the location where the distribution of the food took place (p. 367). In addition, the twelve saw the need of creating a new administrative structure to effectively take care of the ministry to the socioeconomically disadvantaged and to allow them the time to continue the ministry of preaching and praying. Thus, it can be concluded that they saw community ministries as an integral part of the early church, and one that should be continued. To this end, they brought a suggestion to the rest of the disciples. They asked that seven deacons be appointed to help fulfil the demands of ministry to the socioeconomically disadvantaged. These new officers were to have some of the same qualifications of the disciples. They were to be men of good reputation and filled with the Holy Spirit. The church listened and found seven men who were appointed by the laying on of hands. E. G. White (1911) stated that the seven took careful notice of the needs of the church (p. 89). As a result, the church kept on growing. 
While the system of distribution to the widows is not outlined in detail in Scripture, it is reasonable to conclude that there was the creation of a system of

governance. Consequently, the early church, like Israel, would have developed regulations for the administering of community ministries to the socioeconomically disadvantaged within the church.

\section{The Story of Dorcas- A Boundless Mission Paradigm}

Third, Luke (in Acts 9:36-42), mentions Dorcas, a disciple who was well-known for good works and giving alms to the poor. This passage shows an extension of community ministries to the disadvantaged in society. Dorcas exhibited this in her lifestyle in fulfilment of the mission of God. Carson et al. (1994) believed Dorcas always helped the poor, including widows, by making clothing for them (see 6:1).

When Dorcas died, Luke states that there was an outpouring of sorrow by the poor and the disciples, so the disciples sent for the apostle Peter who was in Joppa. Upon his arrival Peter, was shown some of the products, which Dorcas had made. Even though none of the apostles had ever resurrected someone up to this time, Peter performed a miracle and resurrected Dorcas. E. G. White (1911) mentioned that God brought Dorcas back so that the mission could be made more effective (p. 132). Consequently, the resurrection of Dorcas shows that a community ministry to unbelievers is an important part of the mission of the church. The story of Dorcas presents a boundless mission paradigm. "She was always doing kind things for others and helping the poor" (Acts 9:36b NLT). 


\section{The Mission of Paul and James}

In addition to the texts mentioned in the book of Acts, two of the apostles of the early church wrote about ministering to the socioeconomically disadvantaged. These are Paul and James, the brother of Jesus. A passage in which the apostle Paul wrote about ministering to the socioeconomically disadvantaged is 2 Corinthians 8:1-24. In this text, the apostle encouraged the Corinthian Church to collect an offering for the Christians in Jerusalem. In using the liberality of the saints of Macedonia, Paul demonstrated that even the poor could give liberally to help other poor Christians. From this passage, it can be observed that Paul saw helping those who were socioeconomically disadvantaged as an integral part of the ministry of the early church. Hoppe (2004) explained Paul’s theological basis for helping the poor as originating from the life of Jesus. Longenecker (2010) also stated that Paul showed concern for the poor in the cities of the Roman Empire.

The apostle James the brother of Jesus also evinced this care. As a result, he wrote extensively in the book of James about caring for the socioeconomically disadvantaged. Longenecker (2010) observed that James care for the poor was similar to that of Jesus. James included ministering to the socioeconomically disadvantaged as a part of true religion (Jas1:27).

Community ministries to the socioeconomically disadvantaged formed an integral part of the mission of God. This mission was noticeable in the ministry of Jesus, the apostles, and disciples of the early church. 


\section{A Theology for Community Ministries for Toronto West Seventh-day Adventist Church}

Claerbaut (2005) stated that "it has been said that Christianity has failed to make an impact in three major areas: the Hindu Culture, the Islamic Society and the major cities” (p. 1). Presently, the Toronto West Seventh-day Adventist Church finds itself ministering in these three areas. The Church is located in one of the world's largest growing cities. As noted in chapter one, Toronto has a population of 2.79 million. In addition, the church is located in Ward 1 Etobicoke North, which is home to people from Asian and Middle Eastern origins. They are devout Muslims and Hindus. Moreover, there are many people who are socioeconomically disadvantaged living in the environs of the church. According to the report of The Toronto Vital Signs, "In one year, poverty in the Toronto Region rose $22 \%$ and the rate of child poverty was up by more than $43 \%$ ” (Macintyre \& Bardwaj (2011, p. 6).

Historically, the Seventh-day Adventist church has been active in ministering to the socioeconomically disadvantaged. It was encouraged to do so by one of its pioneers, Ellen White, who wrote extensively on this area. For example, she indicated, “All around us are heard the wails of a world's sorrow. On every hand are the needy and distressed. It is ours to aid in relieving and softening life’s hardships and misery” (1952, p. 417). Because of her admonition and the encouragement of other pioneers, the church organized a Dorcas Society in 1879 to do community ministries. In spite of the good work of this society and the subsequent development of other forms of ministries to the socioeconomically disadvantaged under the names of Adventist Community Services and Adventist Development and Relief Agency, Sahlin et al. (1994) noted that several major surveys have revealed that although many in North America have heard the name, 
“Seventh-day Adventist,” the church has a very "soft public image” (p. 11). As a result, when compared with other institutions like the Salvation Army, the church is not as wellknown for its ministries to the socioeconomically disadvantaged. One reason for this may be because the lived theology of community ministries is not well developed in the local church. Dybdahl (2005, para. 1) declared that “mission and theology go together. True theology should move us to mission and mission rightly practiced should lead to theology." It is hoped that by developing a theology for community ministries, the local church will become more effective in pursuing the mission of God to the socioeconomically disadvantaged.

In applying the theological principles of community ministries to the socioeconomically disadvantaged described in the Old Testament to Toronto West Seventh-day Adventist Church, the following observation may be relevant. The missional model given to Israel included providing for and protecting the socioeconomically disadvantaged. This was intended so that the basic needs of all were met. Thus, the local church should develop an effective system for providing resources and relief to the socioeconomically disadvantaged. In so doing, it ensures that they, too, might experience a quality of life that includes rest and happiness. In addition, the law of release of the seventh year, the law of the Jubilee, the law against taking interest, and the instruction about paying wages on time were given to help ensure that those who were socioeconomically disadvantaged could experience freedom, restoration, and justice. While Toronto West Seventh-day Adventist Church exists in a time and place where there are no laws pertaining to the seventh year, the jubilee, and prohibition of interest, it is important that those who lend money to the socioeconomically disadvantaged should 
avoid taking interest as much as possible. In addition, those who hire the poor should honour the payment of wages on time. Finally, the ministries of the prophets served as reminders and warnings to the nation. They called for a reformation. Thus a theology of community ministries as derived from the people of God in the Old Testament may lead to three kinds of urban social ministries. These are "social reconciliation, social relief, and social reform,” (Claerbaut, 2005, pp. 15, 16).

A theology of community ministries that can be derived from the legacy of Jesus, the apostles, the disciples, and the early church includes mingling with people to discover their needs. The Church is thus encouraged to socialize with its community to discover its needs. Claerbaut (2005) noted, members of the church should consider the social matters of its community. They should then share the findings with the church. (p. 24). After studying these social issues, the church should develop strategies to address the welfare needs of the community. In so doing the church can become more missional in relating to its community. Like the stories of the Good Samaritan and Dorcas the church should help it neighbours in the community who are in need.

\section{Conclusion}

In conclusion, the theology of community ministries is based on the mission of God to redeem his children. Mission stems from who God is: a person of love, mercy, compassion and justice. Because of his nature, the mission of God includes ministering to the socioeconomically disadvantaged. In the Old Testament, God upholds Job as blameless. Job's lifestyle included ministering to the socioeconomically disadvantaged. In addition, God selected Israel to partake of His mission. He gave them stipulations about ministering to the socioeconomically disadvantaged in the commonwealth of Israel. 
By following these stipulations, Israel was supposed to provide for and protect the socioeconomically disadvantaged. This ministry was limited to the commonwealth of Israel. In so doing, they would also become a prosperous and happy nation, recipients of the blessings of God, and others would have looked to them in order to know God. Even though we do not have a Christian commonwealth today, the ministry has left us a legacy about how God thinks of the socioeconomically disadvantaged. From this legacy, we can extract some principles that are still relevant today. Such principles include speaking out against the exploitation of the poor, advocating for the poor to have homes and employment, and caring for the well-being of their families.

In the New Testament, the mission of God found its greatest demonstration in the life of Jesus. As part of his mission Jesus ministered to and told stories about the socioeconomically disadvantaged. He mingled amongst them and ministered to their needs. Jesus extended the mission to the socioeconomically disadvantaged beyond Israel. Through this ministry, the disciples received mentorship in the effective models of ministering to the socioeconomically disadvantaged

After the ascension of Jesus, the disciples established community ministries in the church by creating the office of the deacon. They also wrote to the churches encouraging them to minster to the socioeconomically disadvantaged both at a corporate and individual level.

A theology of community ministries for Toronto West Seventh-day Adventist Church can be developed from the principles utilized by the people of God in the Old and New Testaments and by Jesus to minister to the socioeconomically disadvantaged. Its biblical ratio rationale would include providing for and protecting the socioeconomically 
disadvantaged. Its forms would include social reconciliation, social relief and social reform. The church needs to plan strategically to implement these ministries and would need to be more missional in its ministry to the community. 


\section{CHAPTER 3}

\section{LITERATURE RELATED TO STRATEGIC}

\section{MARKET PLANNING}

It seems to be unusual for successful modern business organizations to operate without a strategic marketing plan. Their success depends on their ability to achieve their mission. Kotler, Armstrong, and Cunningham (2005) observed that "today successful companies at all levels have one thing in common . . . they are strongly customer focused and heavily committed to marketing” (p. 6). This quest of being customer-focused entails new ways of thinking about marketing. Armstrong, Kotler, Cunningham, Mitchell, and Buchwitz (2007) stated that marketing should not be understood as selling, as it has been in the past, but as satisfying customer needs (p. 7). Wrenn, Kotler, and Shawchuck (2010) saw the entire purpose of marketing as finding a need and satisfying it.

Armstrong et al. (2007) indicated that to satisfy customer needs successfully, the first thing a marketer needs to do is understand who the customers are. Wrenn et al. (2010) showed that those who successfully use marketing management start the process of understanding the customers by studying their needs. They also indicate that understanding needs is so essential to marketing that failure to do so and to create products to satisfy needs has led to disaster for many institutions. Armstrong et al. (2007) observed that satisfying human needs is the most fundamental theory undergirding marketing, and that exceptional marketing firms make great efforts to study customer 
needs. These businesses know that failure to understand needs and to offer needssatifying products may lead to failure to accomplish their mission. Thus, Kotler et al. (2005) found that "sound marketing is critical to the success of every organization—large or small, for-profit or non-profit, domestic or global” (p. 70).

Andreasen and Kotler (2003) noted that marketing is primarily appropriate whenever the task of persuading people is necessary. This is applicable to non-profit institutions and is vital for their success (p. 5). They observed that in the non-profit world, this persuasion includes influencing donors to give, people to volunteer, patrons to find help, and employees to be customer friendly (p. 5). Since the churches are non-profit institutions that influence people to provide services that address all of these needs, strategic marketing could be beneficial to the church.

Kurtz (2008) showed that in the last decade of the $20^{\text {th }}$ century, organizations developed the marketing concept of customer orientation. Griffin (2007) explained that "relationship marketing” is establishing enduring relationships with customers (p. 330). Kurtz (2008) saw relationship marketing as creating and sustaining long-term beneficial relationships with customers, suppliers, employees, and others. Thus, relationship marketing addresses a need for beneficial relationships. Modern businesses use strategic marketing to become customer-focused, develop relationship marketing, and pursue other types of marketing. They do this to offer services that address human needs.

Whereas the purpose of business is to create and keep customers, two of the purposes of the church are to create and keep members (Matt 28:18-20; John 15:16) and to do good to all men (Gal 6:10). In this instance, both businesses and churches are providing services to meet the needs of people. Barna (2000) found from a national 
survey in the United States that people who did not attend church would be willing to visit a church that was committed to meeting the needs for care and consideration of unchurched people. Modern businesses seek to satisfy the needs of people effectively by developing a strategic marketing plan that is customer-focused and relationship-oriented. Churches that desire to become more effective in reaching unchurched people may want to explore using strategic marketing to meet the needs of their community and customers.

This literature review examines works published about strategic marketing planning between 2000 and 2013 for businesses and churches. Due to the nature of the project, this is not an exhaustive review of literature on the subject. Four aspects of strategic market planning will be reviewed: (a) definitions of marketing, strategic marketing and strategic market planning, (b) the strategic marketing planning process: an overview, (c) marketing for churches, and (d) strategic marketing for churches.

\section{Definitions of Marketing, Strategic Marketing and Strategic Market Planning}

\section{Marketing}

Marketing in the $21^{\text {st }}$ century is a diverse and extensive area of study and practice. Gilligan and Wilson (2009) stated that the enquiry about what marketing is and what it involves has been the center of much labor over the past 60 years. Out of this inquiry have arisen many definitions having to do with the diverse aspects of marketing such as the process, functional activities, and philosophy of marketing. In addition, McDonald and Hugh (2011) observed that "there are many definitions of marketing and much confusion about what it is” (p. 2). As a result, this survey of literature will describe some 
of the diverse definitions of marketing. Because definitions are often specific, I consider it is necessary to quote many of them directly in this section of the review.

In keeping with what was stated before about customer orientation of modern businesses, Armstrong et al. (2007) saw marketing at its core as "managing profitable customer relationships” (p. 6). However, in the same study, they stated that marketing is "a social and managerial process by which individuals and groups obtain what they need and want through creating and exchanging value with others" (p. 7). Concerning "needs" and "wants," they noted that "human needs are states of felt deprivation," and "wants are the forms human needs take as they are shaped by culture and individual personality” (pp. 7, 8).

Proctor (2008) noted that "marketing is about managing relationships," and it is also "the management process responsible for identifying, anticipating and satisfying stakeholder requirements and in so doing serves to facilitate the achievement of the organization objectives” (pp. 2, 3). To him, stakeholders are those who have an interest or stake in the organization. This includes "customers, employees, management, stockholders, creditors, suppliers, community, and sometimes even competitors” (p. 2).

McDonald (2007) saw marketing as a process of

defining markets, quantifying the needs of customer groups (segments) within these markets, determining the value proposition to meet these needs, communicating these value propositions to all those people in the organization responsible for delivering them and getting their buy-in to their role, playing an appropriate part in delivering these valued propositions (usually only communications), and monitoring the value being delivered. (p. 4)

Thus, McDonald defined it from a utilitarian perspective. In keeping with this concept of marketing, Bennett (2010) observed that marketing is seen as a process, which facilitates buyers' exchanging something of value (typically money) for something of 
equal value to them (goods or services). Marketing expert Bedburry (2002) believed that there was a dire need for definitional clarity concerning the role of marketing. To him, the best definition about marketing was that it "is the process by which resources are brought to bear against opportunities and threats” (p. 153). Foote (2012) believed that there were misconceptions about marketing and that it was often viewed too narrowly. Thus, he stated, "essentially marketing is nothing more than the process of making a firm better known” (p. 13). A different perspective about marketing as a process came from McDonald and Keegan (2002) who point to marketing as a matching process that brings together the means of a company with the desires of customers.

Other authors see marketing as more than just a process. Bennett (2010) believed that "marketing is all activities after manufacturing that promote and deliver the good or service to the customer” (p. 3). In another study, Andreasen and Kotler (2003) saw marketing as "sound effective technology for creating exchanges and influencing behavior that, when properly applied, must be socially beneficent because its major premise is responding to customer needs and wants” (p. 38).

From the perspective of institutions, The American Marketing Association states the following: "Marketing is the activity, set of institutions, and processes for creating, communicating, delivering and exchanging offerings that have value for customers, clients, partners and society at large” (Definitions of marketing, 2007, para. 1). Another institution, The Chartered Institute of Marketing, defined marketing as "the strategic business function that creates value by stimulating, facilitating and fulfilling customer demand" (Gilligan \& Wilson, 2009, p. 3).

Different authors describe marketing in ways that are similar and different. 
Marketing can be viewed as managing customer relationship, a social and managerial process, an activity, an institution, a technology, and a strategic business function. Marketing can be a complex function for a large company and a simple function for a small business. There seems to be a continual evolution of thought about marketing. To me, marketing is a strategic process and/or relationship through which a person or organization offers to a person or organization a product in exchange for something of value.

Twitchell (2004) observed, “At the macro level, all religions offer the same transaction. They exchange the meaning of life for some investment by the believer” ( $\mathrm{p}$. 48). Thus, churches can be considered as institutions that exchange information about the meaning of life for the commitment of the customers' time, resources, and, in some cases, life. Churches package and offer this information about the meaning of life in different ways. Some churches do this through sermons, books, and media. Customers sometimes acquire this information without having to exchange tangible resources. However, in some instances, people do exchange money to obtain this information when it is offered in books and media.

Beyond this, churches use place marketing to make people aware about their websites, location in the community, and the location of church-sponsored events and services. People exchange their time by visiting church websites, locations, events, and services. Furthermore, some churches use social marketing to promote healthy living lifestyles, stewardship of the environment, and community services events and programs. People exchange time and money to attain a healthy living lifestyle. They sometimes also commit other resources to take better care of the environment. 


\section{Strategic Marketing and Strategic \\ Market Planning}

Just as there are varied definitions for marketing, there are also various definitions for strategic marketing. There is a variety of definitions because different authors use dissimilar terms while referring to the same process. In addition, the historical development of strategic market planning has contributed to different ways of viewing the same process and doing planning. In his analysis of the history of the development of strategic market planning, Paley (2000) pointed out that the 1980s saw the development of strategic market planning, which combined the strategic plan and the market plan. Since a strategic marketing plan is a combination of two types of planning, it is impacted by views of strategic planning. Mintzberg (as cited in Gilligan \& Wilson, 2009) indicated that there are 10 views of the strategy process, including “The Design School, The Planning School, The Positioning School, The Entrepreneurial School, The Cognitive School and The Learning School” ( pp. 45, 46). Consequently, authors may be looking at the strategic marketing process from one or more viewpoints.

Some authors refer to strategic market planning as a type of marketing planning. In one study, Drummond, Ensor, and Ashford (2008) indicated that "there are two types of marketing planning — strategic and tactical” (p. 246). As a result, they wrote that strategic marketing takes a longer-term time frame and broadly defines the organization's marketing activities (p. 246). Paley (2000) noted that some companies might refer to strategic market planning as strategic planning, business planning, or market planning.

Similar to marketing, strategic market planning is viewed as a process by some writers. Brennan et al. (2008) saw "strategic marketing as identifying changes taking place in the market and business environment, and then ensuring that the firm is well 
prepared to meet them” (p. 13). In some instances, the process is called a strategic plan. Lake (2011) defined it as "the planning process that yields decisions in how a business unit can best compete in the markets it elects to serve. The strategic plan is based upon the totality of the marketing process” (Introduction section, para. 1). Paley (2000) described strategic marketing "as a total system of interacting business activities designed to plan, price, promote, and distribute want-satisfying products and services to end users in a competitive environment at a profit” (p. xxvii). Berkowitz, Crane, Kerin, Hartley, and Rudelius (2003) saw strategic market planning as a process whereby an organization allocates its marketing mix resources to reach its target markets. They observed that it is so important to the performance of most organizations that it is formalized as a marketing plan. Sandhusen (2008) viewed strategic marketing in a similar way when he said, "strategic marketing planning is the managerial process of developing and maintaining a strategic fit among the organization's resources and objectives and its changing market opportunities” (p. 49).

Gilligan and Wilson (2009) posited that strategic marketing planning is about defining marketing objectives and how they can be achieved over a three- to five-year period. This concept about the planning process being utilized to create marketing objectives is also found in the definition of Ryans, More, Barcaly, and Terry (2000). They stated, "Strategic market planning is the process by which a company selects and creates the business opportunities it will pursue and develops the marketing plans that will propel it to market leadership in its targeted markets” (p. 10). 


\section{The Strategic Marketing Planning Process: An Overview}

As noted before, the different definitions of strategic market planning suggest that different writers view the planning process differently. Thus, there are differences and similarities as to what is to be included in the process of strategic market planning. This can be seen in the way in which different authors write about how the process should begin. Drummond et al. (2008) posited that strategic marketing has three phases: strategic analysis, formulating strategy, and implementation. In their formulation, the process began with strategic analysis.

Andreasen and Kotler (2003) began first by drawing attention to the development of systematic processes for implementing effective marketing. They argued that, organizations should have longer-range marketing plans, a process that is encapsulated as Organizational Marketing Planning or OMP, as well as short-term marketing plans referred to as Campaign Marketing Planning or CMP. Just like Drummond et al., Andreasen and Kotler (2003) supported the three phases of the strategic marketing planning process. In both cases, the process began with the analysis phase. This is illustrated in Figure 1.

Sandhusen (2008) indicated that the strategic marketing process begins with the development of a mission statement. This statement is developed from the thorough analysis of the company and its marketplace. His model can be seen in Figure 2.

Therefore, inherent in his concept of the start of the process is an internal and external analysis of the environment. His perception is that strategic market planning is a 
top-down process which begins at the corporate level. Sandhusen (2008) further conceptualized the process as starting with corporate-level strategic planning. He also used the terms of strategic market planning and strategic planning interchangeably. In addition, he sequentially included goal formulation, strategy formulation, program formulation, implementation, and feedback and control in the process.

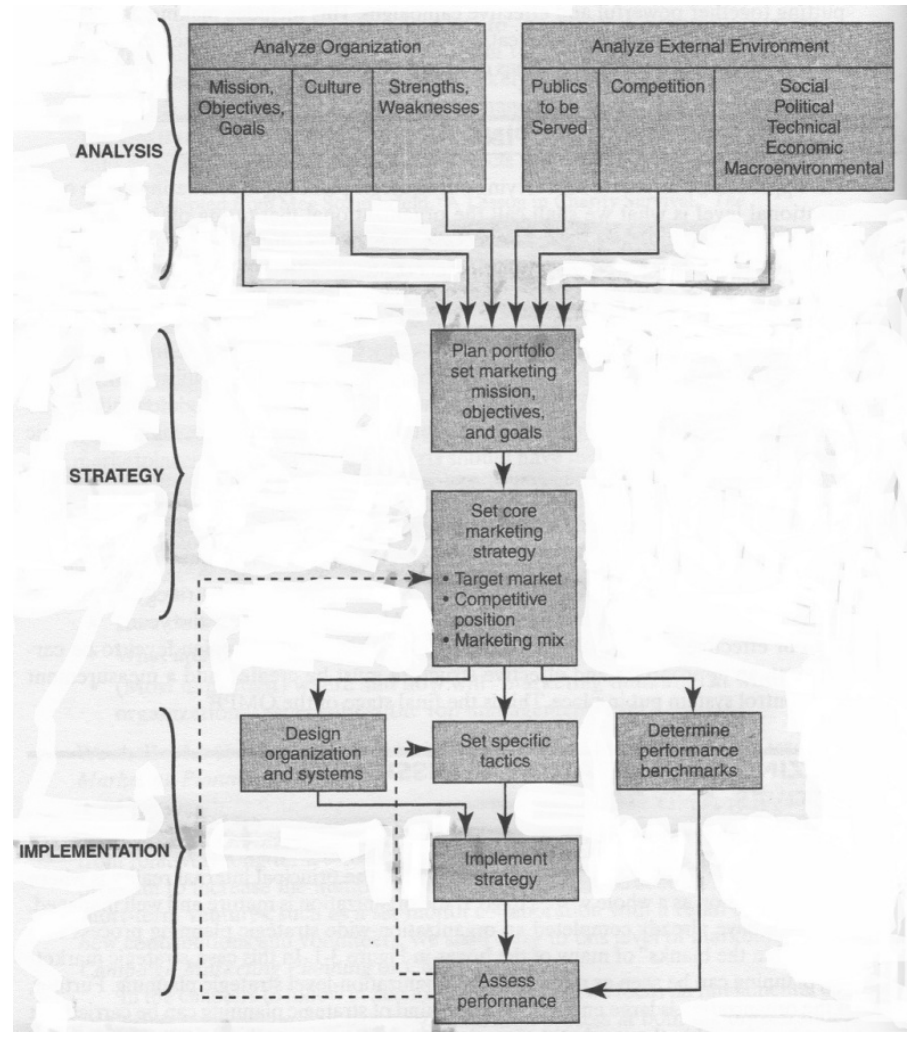

Figure 1. Strategic organizational marketing planning process. Adapted from "Strategic Marketing for Non-profit Organizations" by Andreasen and Kotler (2003), p. 66. Copyright 2003 by Pearson Education, Inc. 


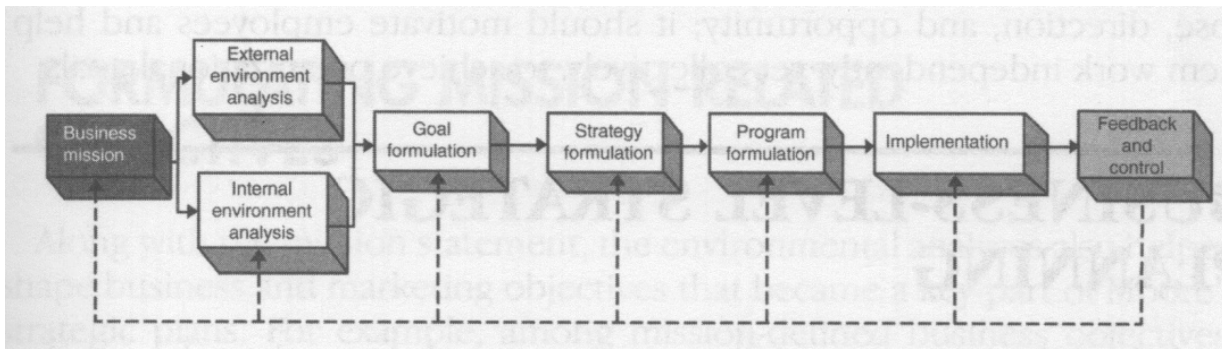

Figure 2. The business strategic_-planning process. Adapted from "Marketing" by Sandhusen (2008), p. 49. Copyright 2008 by Barron Education, Inc.

Therefore, inherent in his concept of the start of the process is an internal and external analysis of the environment. His perception is that strategic market planning is a top-down process which begins at the corporate level. Sandhusen (2008) further conceptualized the process as starting with corporate-level strategic planning. He also used the terms of strategic market planning and strategic planning interchangeably. In addition, he sequentially included goal formulation, strategy formulation, program formulation, implementation, and feedback and control in the process.

Whereas Sandhusen (2008) seemed to identify strategic market planning as the same process as strategic planning, Sommers and Barnes (2001) saw strategic market planning as a subset of strategic planning which is developed after "Strategic Company Planning," and which belongs to a functional area of the firm (p. 61). As a result, Sommers and Barnes (2001) divided the process into five steps: conducting a situational analysis, developing marketing objectives, determining positioning and differential advantage, selecting target markets and measuring market demand, and designing a strategic marketing mix. It is noticeable that the strategic marketing planning process began with analysis. 
On the other hand, Gilligan and Wilson (2009) saw the strategic marketing plan as emerging from the marketing strategy of the firm. The marketing strategy is a subset of the corporate strategy. According to these two authors, in order to develop the strategic marketing plan, "the strategist needs to take as one of the starting points the analysis of the three Cs of strategy: customer, competitors, and capabilities” (p. 50). Moreover, the same authors have developed two different models of the strategic marketing process. The first model has five stages which begin with the identification of key external issues, then proceed to analysis, strategy planning, action, and tactical planning, and end with implementation, monitoring, and control. The second model has six stages. It begins with the core purpose; this is followed sequentially by the Olympic goal or vision, strategies and action plans, customer service and customer delight, profitable growth, and operational efficiency (Gilligan \& Wilson, 2009, p. 51).

After critically examining the writings of three of the most well-known international marketing experts—Phillip Kotler, Malcolm McDonald, and David Cravens—-which they had produced over a period of 30 years, Smith (2005) concluded that the core process of strategic market planning had not changed (p. 15). In additon, he identified this core process that underlies all the textbooks and the confusing array of terminology and approaches of strategic market planning as consisting of three parts: "understanding the market, choosing the strategy, and deciding the actions” (p. 19). In his opinion, the process of understanding the market included the assessment of the internal and external situation. Therefore, he began the process with analysis.

McDonald (2007) divided the process into four phases: goal setting, situation review, strategy formulation, and resource allocation and monitoring. Therefore, he did 
not begin the planning sequence with analysis. Unlike McDonald, Berkowitz et al. (2003) divided the process into three phases: "planning, implementation, and control” (p. 42). They begin the planning phase with a SWOT analysis. SWOT is an acronym, which stands for an appraisal of a company's strengths and weaknesses and the opportunities and threats present in its external environment (Thompson, Strickland, \& Gamble, 2008, p. 97).

Thus, regardless of the structure or composition of the strategic marketing process, which was highlighted in the literature reviewed, all the aforementioned writers include analysis, strategy development, and implementation as basic ingredients of the strategic marketing planning process.

The Situation Analysis

There are different views of the strategic marketing planning process. Different names are given to the phase of analyzing the situation. The authors differ on how and when to conduct a situation analysis. McDonald and Keegan (2002) stated that their "research has shown that in the murky depths of an organizational behavior, when it comes to marketing planning, confusion reigns supreme-and, nowhere more so than over the terminology of marketing” (p. 18).

Gilligan and Wilson (2009) called the situation analysis the marketing audit and stated that it is the true beginning point of the strategic marketing planning process. This audit entails the external environment, which includes the business and economic environment and is categorized as "PEST"-political, economic, social/cultural and technological factors. The audit is also done on the market and on the competition. Furthermore, the marketing audit also encompasses the internal environment of the 
company and takes into consideration the organizational performance and structure, as well as its operations and resources (p. 79). McDonald (2007) also referred to this analysis as "the marketing audit" which entails a review of the external and internal environment. In addition to what is included in the external audit by Gilligan and Wilson, McDonald added an audit of the legal, fiscal, and intra-company context.

Berkowitz et al. (2003) noted that the core of situation analysis is understanding where the company and product were recently, are presently, and where they are going based on the firm's plans, environment, and trends that impact the firm (p. 42). For these writers, the situation analysis (SWOT) includes identifying industry trends, analyzing competitors, assessing the company, and researching the customer. As previously mentioned, McDonald and Keegan (2002) noted that there is confusion over market planning, I believe that the process should begin with situation analysis. It is only by knowing and understanding its current position that a firm can utilize business intelligence to grow. Therefore, the analysis should include what the organization did in the past and is currently doing. In addition, it needs to include an evaluation of its operating environment to determine potential threats and future growth possibilities.

\section{The Development of Strategy}

After analyzing the marketing situation, many business companies and entities use the information that they have gathered to develop marketing strategies. Smith (2005) saw this part of the process as taking input from the knowledge acquired by studying the market (p. 19). Gilligan and Wilson (2009) observed that the process of strategic market planning is based on the assessment of the markets by the planning team and awareness of business entity capabilities, as well as manager expectations. McDonald (2007) noted 
that the key purpose of marketing strategy is the selection of customers. Thus, Smith (2005) concluded that "the development of marketing strategy has to do with deciding who to target and what to offer them” (p. 19). In a similar manner, McDonald (2007) defined marketing strategy as the method through which a company attains its marketing objectives and is typically concerned with the four Ps. The four Ps are considered the essential variables of the marketing mix. The term "marketing mix" is used to refer to "the set of controllable, tactical tools that the firm blends to produce the response it wants in the target market.” Marketers classify these tools as product, price, place, and promotion (Armstrong et al., 2007, p. 67). A product can be goods, services, or ideas or a combination of these that is offered to the market. The price is what is exchanged for the product. The promotion is the communication between the seller and buyer, and the place is the location where the customers can acquire the product (Armstrong et al., 2007, pp. 67, 68; Berkowitz et al., 2003, p. 15).

In addition to the four Ps, service organizations include three additional Ps in their marketing mix. These are people, physical evidence, and processes. People are defined as human beings who take part in the delivery of the service and in so doing impact the perception of the customer. They are the employees and /or volunteers of the firm, buyers, and customers in the services environment (Zeithaml, Bitner, \& Gremler, 2006, p. 26). The physical evidence is the surrounding in which the customer and organization relate, as well as the service received (Proctor, 2008, p. 239). The process is the delivery system through which the service is rendered (Zeithaml et al., 2006, p. 27).

In order to develop a marketing strategy successfully, business organizations use the information gathered from their SWOT analysis for the purpose of market 
segmentation, targeting, and position. Market segmentation involves placing prospective buyers into groups that have similar needs and will respond in the same way to a marketing initiative (Berkowitz et al., 2003, p. 269). Markets can be segmented geographically, demographically, psycho-graphically, and behaviorally (Kotler et al., 2005, p. 320). Once the market has been segmented, marketers then determine which segment will best fit the organizational profile and develop a marketing plan to target that segment. This segment becomes a target market. Thus, a target market consists of a group of customers with similar traits (Kotler et al., 2005, p. 346). Once the target market is selected, the company will decide how to position itself in this market. The strategy of positioning is that of locating a brand or firm in the customers' mind so that its qualities are distinguished from its competitors (Sommers \& Barnes, 2001, p. 138). This is achieved by using the variables of the marketing mix, which includes how the product is made and packaged, advertising, and quality of service (Proctor, 2008, p. 193; Sommers \& Barnes, 2001, p. 139).

After the development of the strategy, some authors indicated that organizations should then proceed to writing the marketing plan. This plan is used in the next stage, the implementation of the strategy.

The Implementation and Control

Smith (2005) referred to this part of the process as creating the action plan and noted that it entails making decisions about product, pricing, service, promotion, and channels to market. Armstrong et al. (2007) noted that implementation is turning the marketing plans into marketing actions that lead to the accomplishment of the strategic marketing objectives. In their perspective of the planning process, Sommers and Barnes 
(2001) observed that strategic market planning would lead to the development of an annual marketing plan, which will focus primarily on implementation. Their annual marketing plan, tactics, financial scheduling, and timetabling comprise the implementation phase. Thus, the implementation has to do with the allocation of resources to different parts of the firm to produce the marketing mix the company desires in order to generate the valued offering to the market place. Andreasen and Kotler (2003) placed implementation under the designation of the short-term market planning campaign. They observed that two important aspects of implementation are ensuring that responsibilities are assigned and performance deadlines are in place. These help to keep the plan focused on its objectives.

The essential components of product production—selling price determination, promotion, and distribution operations—-may come at different points in the marketing plan, based on which author is writing. What is important is that the marketing plan be well implemented. Once the plan is implemented, it must be controlled. Drummond et al. (2008) stated that control should be measurable. It is a way of comparing what is expected to happen with what has happened or most likely will happen. The systems of control often create a feedback loop (p. 289). As was observed before, Berkowitz et al. (2003) separated the implementation phase from the control phase. In their system of planning, the control phase is the final phase of the strategic marketing process. It is used to compare the end result with the intended outcome. It entails the comparison of goals and results, the identification of deviation, and the formulation of new plans and actions in order to solve problems and capitalize on opportunities (Berkowitz et al., 2003, pp. $598,599)$. 


\section{Marketing for Churches}

Literature relating to marketing for the church shows two emphases: those who see the use of modern marketing methods by the church as beneficial and those who see it as detrimental. Literature relating to those who support the use of marketing for churches will be examined first.

\section{Those who Support Church Marketing}

In an article about the growth of successful megachurches, A. Kuzma, A. Kuzma, and J. Kuzma (2009) observed that religion is, in many ways, a growth industry. One of the factors that contributed to the growth of successful megachurches is their understanding and use of "sophisticated marketing.” These churches use marketing research, segmentation, positioning, branding, product development, integrated marketing communications, and distribution strategy (p. 2). The authors further suggested that it would possibly be hard to find any church in the United States that has not looked into the use of marketing. In addition, they concluded that the success of the megachurch is a model of how marketing can be effectively utilized. George Barna (as cited in Considine, 2001a, p. 36) found that churches making a difference in their communities, and attracting more and more people, are market-oriented. In addition, Reising (2006) supported the use of marketing by churches. He defined marketing as the management of perception. He mentioned the use of over 30 references in the Bible that refer to Jesus' perceiving people's perception and changing the direction of his ministry. He adjusted or halted his communication because of what he observed. Therefore, Reising (2006) suggested that there is a biblical foundation for marketing (p. 25). He further indicated that the Great Commission contains promotion, which is one of the main elements of 
marketing. Moreover, he quoted 1 Corinthians 9:19-23 and pointed out that the foundation of marketing is established in the context of whom you are trying to reach (p. 29). He indicated that Paul used market research in order to reach people with the gospel. Reising (2006) cited many other examples from the Bible, showing how different aspects of marketing were used.

\section{Those who do not Support Church Marketing}

On the other hand, Wigg-Stevenson (2009) believed that sales and evangelism are not identical. Therefore, we need to understand the difference between the Truth and a truth which one can sell. He further suggested that we are in peril if we market the church and cannot see the difference. In a culture of marketing, the Truth will become a product. His argument is that the gospel is not a product that we can sell (pp. 20-26). Like WiggStevenson, Webster (1992) indicated in one of the seminal works of those who oppose marketing the church that marketing is not necessary to contextualize the gospel to the baby boomer generation (p. 146).

Consequently, there is a division among authors over the issue of the use of marketing by churches. Wrenn et al. (2010) pointed out that since their publication of Marketing for Congregations 17 years ago, there is still a continual debate about the use of marketing by religious institutions. They invited their readers to ponder the trend of the business press of producing how-to books with useful advice on implementing church marketing and condemnation of the use of marketing largely by the religious press. They go on to question the impasse that exists between the two sides on the use of marketing by religious organizations. 


\section{Churches can use Marketing}

I believe that churches can use marketing within the context of the missional aspects of the church as it relates to service. Wrenn (2011) showed that one of the mission relationship objectives of the church is to offer social services (diakoneo) to its public (p. 46). Kotler, Kartajawah, and Seitewan (2010) indicated that marketing has progressed through three stages: Marketing 1.0 (product centric marketing), Marketing 2.0 (consumer centric marketing), and Marketing 3.0 (Values-driven marketing) (pp, 4, 6). He stated that in Marketing 3.0, people are considered as whole human being with minds, hearts and spirits. These consumers are looking for companies which speak to their deepest needs for social, environmental, and economic justice (p. 2). Wrenn, Hoover, and Warwick (2013) stated that the core philosophy of marketing maintains that within the construct of, marketing as exchange, focusing on consumers' needs and wants engenders the best success. Since consumers are searching for companies that meet their needs for environmental, social, and economic justice, churches can become involved in social marketing of biblically relevant programs that speak to these needs. Such programs may address some of the economic and social needs which are by-products of poverty and environmental pollution. Churches may become involved in relationship marketing by providing services such as anger management to help people develop better relationships with themselves and others.

\section{Strategic Marketing for Churches}

Wrenn et al. (2010) indicated that

all marketers have been admonished to think of what they offer as providing a service to address a need, rather than as an object to sell. It is in fact the service mentality, or 
concern with addressing the needs of others, that provides the common ground upon which marketing thought and religious institutions stand. (p. 17)

They further posited that restricting the use of marketing to the purposes of fellowship and ministry in no way unnecessarily limits the ability of marketing to make meaningful contributions to religion. Hence, it is possible to use marketing for some aspects of ministry without venturing into aspects of theology, which are unrelated to marketing. As a result, Wrenn et al. (2010) discussed strategic market planning in their work. In the discussion, they stated that "planning from a marketing perspective can be thought of as two processes:" strategic planning and marketing planning. "Strategic planning is the process of developing and maintaining a strategic fit between the organization's goals and resources, and its changing marketing opportunities" and "marketing planning is the process of selecting target markets (groups to be focused upon), choosing a strategic position, and developing an effective marketing mix to reach and serve the target groups and achieve organizational goals” (pp. 303, 304).

Further, Wrenn et al. (2010) used a marketing plan to demonstrate how religious institutions can utilize these two processes. Their marketing plan format included the following in sequential order: mission statement, situation analysis, target market, marketing strategy, design and implement marketing tactics, marketing budget, and marketing control. They then cited The First Church in Carmel, Indiana, as an example of the effective use of a marketing plan for churches.

In addition, Considine (2001b) wrote about the benefits of developing a marketing plan for religious organizations. Some of these benefits are helping the organization to determine its focus, assessing alternatives, determining opportunities for growth, observing threats to growth, effectively and efficiently utilizing its resources, and 
determining the allocation of responsibilities. He suggested a marketing plan format that includes developing a mission statement, conducting a situational analysis, identifying goals, developing objectives, designing marketing strategy, selecting marketing tactics, and providing marketing control. A senior marketing student who conducted an actual case study at Christ Episcopal Church Albion demonstrated the practicality of this format. Haines (2001, as cited in Considine, 2001b) believed that it was necessary for religious institutions to give consideration to more formal marketing plans in order to help facilitate the development of appropriate goals and objectives and design realistic strategies and tactics that enable them to straddle the trying years ahead.

\section{Summary and Conclusion}

\section{Summary}

Modern successful businesses generally do not operate without a strategic marketing plan because they are committed to marketing by being customer-focused. They operate from the perspectives of understanding the needs of the customers, creating products to satisfy the customer's needs, and building enduring relationships. Churches need to be customer-focused because they are in the business of creating members and doing good to all people. They can become more effective by understanding the needs of their customers, by creating products to address those needs, and building enduring relationships. Strategic market planning can enhance the effectiveness of churches in pursuing their purposes. The literature review entailed works published on strategic marketing between 2000 and 2013. The four areas that were examined included (a) definitions of marketing, strategic marketing, and strategic market planning; (b) the strategic marketing planning process: an overview; (c) marketing for churches; and (d) 
strategic marketing for churches. The literature reviewed revealed that there are different definitions for marketing and strategic market planning. Marketing is viewed as managing customer relationships, a social and managerial process, an activity, an institution, a technology, and a strategic business function. Strategic marketing is described as strategic planning, business planning, market planning, and a managerial process.

The literature reviewed showed that authors share similar as well as different perspectives on the process of strategic market planning. Most authors included analysis, strategy development, and implementation as basic ingredients of the process. However, their approaches to these are sometimes similar and sometimes different.

Regarding marketing and strategic marketing for churches, there are two perspectives: those who see the use of marketing as beneficial to the church and those who see it as detrimental. There is currently an unresolved impasse between these opposing views. However, some writers have shown that churches can use strategic marketing successfully and beneficially.

\section{Conclusion}

From the literature review, I gleaned that churches can use marketing successfully to deliver services that are non-salvific, such as food and clothing banks for their communities. There are two directions of relationships which are developed from the mission of a church. These are vertical and horizontal. The vertical direction is about developing a relationship between God and man. The horizontal direction is about fostering a service mentality and cohesiveness among people. These two directions of the relationships of a religious institution can be summarized as spiritual (vertical) and social 
(horizontal). In addition to the direction of the relationship, there are two kinds of audiences, which are served by the mission of the church. These are the internal audience and the public. The vertical relationship, which has to do with worship, discipleship, and evangelism, cannot and should not be marketed. However, the horizontal relationship, which is about the creation of community and offering social services to the public, can be marketed. As a result, where it is in keeping with their mission statements, churches can utilize the following types of marketing: (a) place marketing, (b) relationship marketing, (c) adherent marketing, (d) social marketing, (e) fellowship marketing, and (f) social services marketing.

I further learned that religious marketing is different because not everything that falls within the mission of religious organizations is marketable. Religious organizations are interested in transformation and commitment to godly living. Marketing can assist them in attaining such goals by transforming self-interest to selfless interest in the welfare of others. This can happen when members set aside their interest in providing services that meet the needs of others.

Since churches can use marketing for providing social services, I gathered from this review that an effective way of doing this is by developing a strategic marketing plan. In so doing, I would conduct a situation analysis to determine the needs of the community and the state of the church. I would use the results of the situation analysis to develop strategies to reach the community. When the strategies have been developed, I would implement and control the strategic marketing plan. An assessment of the plan would be done to determine its effectiveness. In conclusion, churches can use marketing 
especially in the area of providing social services where possible to meet the needs of their communities. 


\section{CHAPTER 4}

\section{METHODOLOGY}

\section{Introduction}

In this chapter, there is a description of the development and implementation of the strategic marketing plan for Toronto West Seventh-day Adventist Church. B. White (2000) stated, “The approach a researcher uses to investigate a subject is termed the methodology.” Further, methodology can be defined as the philosophical base upon which the research is founded (p. 20). In addition, B. White noted that "research is a process, a series of activities unfolding over time. It involves a number of things, for example: the choice of the research design, the collection of data, and the evaluation of the results” (p. 23).

This project is a qualitative study that includes marketing research. As a part of the process, semi-structured interviews were conducted to acquire primary data that were then used to develop and implement a strategic marketing plan for the Community Ministries Department at the Toronto West Seventh-day Adventist Church.

The development of a strategic marketing plan entails doing marketing research. Brennan et al. (2008) stated, "Strategic marketing is concerned with identifying changes in the market and business environment, and ensuring that the firm is well prepared to meet them” (p. 13). Wrenn, Stevens, and Louden (2002) stated that the American Marketing Association's definition of marketing research is 
the function which links the consumer, customer, and public to the marketer through information - information used to identify and define marketing opportunities and problems; generate, refine and evaluate marketing actions; monitor marketing performance; and improve understanding of marketing as a process.

Marketing research specifies the information required to address these issues; designs the method for collecting the information; manages and implements the data collection process; analyses the results and communicates the findings and their implications. (p. 2)

In addition, Wrenn et al. (2010) noted that marketing research includes discovering answers to marketing problems and making more appropriate choices. Further, according to Andreasen and Kotler (2003), “any reliable information that improves marketing decisions can be considered marketing research” (p. 120).

\section{The Background to the Study}

As indicated in chapter one, Toronto West is a large Seventh-day Adventist church, with a membership of 1,306. It is located in the diverse, multicultural, multiethnic, and multi-religious urban community of Etobicoke North in Toronto. The population in the church's neighborhood is a growing immigrant population, and the community is undergoing a demographic transition. Understanding that the neighborhood is changing and that many in this growing immigrant population do not know Christ, the church has tried to reach its neighborhood by hosting a number of community ministries events such as a free mid-week community meal and Thanksgiving community dinners. In spite of these efforts, many of the community services events are not well attended. In 2012, the Community Services Department held a community ministry event for the community called The Day of Love and Care. Even though some advertising was done, only 35 persons from the community attended the event. It should be noted that this was the second time this event was hosted, and it was hoped that over 100 community 
members would attend. Further, a review of the years 2006-2012 revealed an attendance of less than 50 persons from the community attending any program conducted by the Community Services Department. In an effort to improve the attendance, I hypothesized that the development and implementation of a strategic marketing plan might lead to the identification of a solution or solutions to the problem.

This chapter on methodology includes the qualitative method, the subjects or participants, and the process of developing and implementing the strategic marketing plan.

\section{The Qualitative Method}

“Qualitative research is a method of inquiry employed in many different academic disciplines, traditionally in the social sciences, but also in market research and further contexts” (Qualitative research, n.d., para. 1). According to Saldana (2011), qualitative research is a general term for a great diversity of methodologies, which are used to study social life (p. 3). The qualitative method investigates the why and how of decision making not just the what, where, and when. A small focused sample is recommended over a large sample when conducting a qualitative investigation (Qualitative research, n.d., para. 1).

Saldana (2011) stated,

The information or data collected and analyzed is primarily (but not exclusively) nonquantitative in character, consisting of textual materials such as interview transcripts, field notes, and documents, and/or visual materials such as artifacts, photographs, video recordings, and internet sites, that document human experiences about others or one's self in social action or reflective states. (pp. 3, 4)

Alston and Bowles (2003) noted that "from careful observations, immersion in the world of 'the researched,' in-depth interviews and...other techniques, qualitative 
researchers build their theories from patterns...in the data” (p. 9). They also noted that the challenge of qualitative research is “to understand reality from the 'inside,' from other people’s perspectives” (p. 10).

The marketing research that was used in this project included needs identification and situation analysis. Alston and Bowles (2003) stated, "Need identification is a process of identifying health and social service requirements in a geographic and social arena whereas needs analysis is a process of prioritizing the identified needs” (p. 124).

The needs identification and analysis were conducted through the use of semistructured interviews. Kvale (2007) observed that one of the main ways of acquiring data in qualitative research is through interviews (p. xv). The interview approach was chosen because it allowed for immediate clarification of data. In addition, I was able to understand the reality of the needs from the interviewee's perspective. According to B. White (2000), interviews facilitate face-to-face communication between interviewer and interviewee and this provides the benefit of clarifying any misinterpretations during the interview (p. 29). Polonsky and Waller (2011) noted,

The semi-structured interview differs from the personally administered questionnaire because it gives you an opportunity to gather in-depth responses that reflect the insights of the interviewee. It also allows you to probe into issues and pursue unexpected revelations, hence the term semi-structured. (p. 153)

In this study, 16 interviews were conducted in order to ascertain the real needs and felt needs of Etobicoke North. Regarding the selection of participants to interview, Saldana (2011) stated that, “a small group of three to six people provides a broader spectrum of data for analysis, while others attest that a minimum of 10 to 20 participants is needed to ensure more credible and trustworthy findings” (p. 34). The number 16 was chosen for a few reasons. First, the number 16 was within the range of 10 to 20 . Next, 
since the interviews were time consuming in nature, I chose to conduct only 16 interviews. Sahlin (2004) indicated that doing an appraisal of community needs individually takes substantial time. Another reason that influenced my choice of 16 was the cultural diversity in the neighborhood. Initially, it was my intention to conduct 10 interviews. However, an additional six were conducted to accommodate the cultural diversity of the neighborhood. This addition allowed me to interview immigrants from Africa and the Middle East. The last reason for my choice of 16 was that, early into the interviewing process, some of the interviewees provided me with secondary resources. These included researches about Etobicoke North, which were funded and conducted by creditable organizations, including the Government of Canada. Wrenn et al. (2010) indicated that the number one principle of researchers is that they exhaust all available secondary documents before starting to explore primary sources (p. 115). Since I was not aware of these sources before I began the interviews, and the content of these resources confirmed data that was acquired in the interviews, I decided to stop interviewing after the 16 th interview.

\section{The Subjects or Participants}

The participants in this research included the eight leaders of the Community Services Department of Toronto West Seventh-day Adventist Church and 16 members of the North Etobicoke community. The members of the Community Services Department held discussions on the development and implementation of the strategic marketing plan. Sahlin (2004), in writing about methods of community assessments, included interviewing public officials and managers of community organizations and institutions (p. 128). As a result, I included political and community organization leaders, business 
people, educators, non-profit organization leaders, and individuals of the various ethnic backgrounds that constitute the neighborhood of the church in my interviews. Each of the interviewee was above 18 years of age.

Based on the recommendation of my context support group, nonprobability sampling was employed to select the community participants. According to Polonsky and Waller (2011), this sampling technique allows the researcher to use personal judgment to select the composition of the sample (p. 140). In selecting the interviewees, I made the assumption that they were knowledgeable in the needs of the community.

\section{The Strategic Marketing Planning Process}

In chapter three, the literature review, it was noted that different authors used different approaches in the development of a strategic marketing plan. However, they all agreed on the inclusion of the analysis of the situation, the development of strategy, and implementation of the strategy as basic components of the strategic marketing planning process. In addition, some authors included mechanisms of control during the implementation process as an important aspect of a strategic marketing plan. In this project, I included the aforementioned four components: situation analysis, strategy development, implementation, and control in the development of the strategic marketing plan.

Mission Statement and the Situation Analysis

Wrenn et al. (2010) suggested that the development of marketing plans should start with a mission statement. They noted that the mission statement addresses the "purpose of the church (What are we trying to accomplish?)” (p. 308). In addition, 
Withers and Vipperman (2003) indicated, that it is important to have the company's mission at the beginning of the marketing plan because it helps one to focus his/her energy as he/she prepares and implements the plan (p. 9). They also stated that the marketing plan consists of the answers to three questions. The first question has to do with where the firm is presently. In order to answer this question, an internal and external situation analysis of the firm must be done. This analysis begins with an examination of the mission statement (p. 7). Accordingly, without an examination of the mission statement, it could be difficult to begin to conduct a situation analysis of a firm or church since the purpose of the organization may be obscure.

Regarding the situation analysis, Gilligan and Wilson (2009) placed it within the context of a marketing audit and stated that it is the true beginning point of the strategic marketing planning process (pp. 78, 79). They also noted that the situation analysis is the means by which the strengths and weaknesses of the organization can be assessed alongside the context of the market and the prospects and risks that exist (p. 78).

The strategic marketing planning for Community Services Department began with an examination of the church's mission statement:

The Toronto West Seventh-day Adventist Church, through God's grace will spread the good news of salvation to mankind, and live in harmony with His commandments, while fulfilling the spiritual and social needs of its congregation and surrounding community.

Since fulfilling the spiritual and social needs of the community is included in this statement, the leaders of the Community Services Department considered the following questions: (a) What are the spiritual and social needs of the community? and (b) Does the department have a relevant mission statement that seeks to address fulfilling these needs? From the discussion, the department concluded that they needed a mission statement. The 
Community Services Leader then suggested a mission statement. However, at this stage of the planning, the department had not conducted a needs assessment for the Etobicoke North Community. According to West, Ford, and Ibrahim (2010), strategic market planning is a method that enables an organization to create a strategic fit between its competencies and the threats and opportunities emanating from its varying environment (pp. 52, 53). Since the capabilities of the department had not been determined and the threats and opportunities had not been assessed, I thought that the department was not in a position to arrive at a focused customer mission statement. Therefore, the second part of the church’s mission statement—- "fulfilling the spiritual and social needs of the community,"-was used as a starting point to conduct the SWOT (Strength, Weakness, Opportunity, and Treat) analysis.

Proctor (2008) indicated that a SWOT analysis enables the identification of organizational strategies by detailing and connecting strengths, weaknesses, opportunities, and threats (p. 143). Gilligan and Wilson (2009) noted that strengths are parts of the firm where it has a unique capability and weaknesses are parts of the firm where there is a comparative shortcoming (p. 86). They also indicate that strengths arise from the "market asset base" of the firm and weaknesses show zones and approaches that should be excluded from the planning process (p. 86). Therefore, conducting the SWOT analysis is an important activity that leads towards the development of marketing strategy.

In conducting the internal part of the SWOT analysis, information was gathered from both primary and secondary data. The secondary data was derived from the records of past community ministries events. Andreasen and Kotler (2003) observed that the 
internal records of an organization help in understanding how it is performing (p. 124). The primary data was collected from the discussions held between the Community Ministries Departmental leader and members concerning the strengths and weaknesses of the department. These discussions took place during the departmental meetings. Both the primary and secondary data were collected and assessed.

\section{Opportunities and Threats}

Following the determination of the department's strengths and weaknesses was the next step in the methodology, the situation analysis of the external environment. This step was necessary to ascertain the opportunities and threats. In reviewing both the records of the church and the Community Ministries Department, there was no indication that a situation analysis of the external environment had ever been done before, and neither were there any documentation of opportunities and threats.

According to Wrenn et al. (2010), the analysis involves examining the local and national socio-economic, socio-cultural, and demographic trends that could affect the achievement of objectives (p. 308). In addition, they stated that the trends or happenings can be classified as opportunities or threats (p. 308). Gilligan and Wilson (2009), in describing opportunities, defined them as environmental tendencies with positive outcomes. They posited that if these tendencies are utilized effectively, they can result in greater levels of performance (p. 86).

With respect to threats, Wrenn et al. (2010) stated,

An environmental threat is a challenge posed by an unfavorable trend or specific disturbance in the environment that, in the absence of purposeful marketing action, would lead to the stagnation, decline, or demise of a religious organization or one of its ministry programs. (p. 314) 
In order to analyze the environment for opportunities and threats, Iacquired data from external primary and secondary sources. Kurtz (2008) noted that marketing research projects often combine secondary and primary data in order to respond to marketing questions (p. 235). The secondary sources for this project included the websites of the Government of Canada and businesses, and published materials about Canada, the City of Toronto, and Etobicoke North. According to Aaker, Kumar, and Day (as cited in Polonsky \& Waller, 2011), the following questions should be asked when looking at secondary sources:

1. What was the purpose of the study?

2. Who collected the information?

3. What information was collected?

4. When was the information collected?

5. How was the information obtained?

6. Is the information consistent with other studies? (p. 133)

As I examined the secondary sources for this project, I gave consideration to all the questions mentioned above.

\section{The Interviews}

The primary sources for the marketing research were the interviewees. These individuals were selected from within the public of Etobicoke North. Kotler et al. (2003) noted that "a public is a distinct group of people, organizations, or both whose actual or potential needs must in some sense be served” (p. 74). I contacted some of the potential interviewees in person and others, by phone. At the time of initial contact, I requested an interview appointment with each of the potential interviewees. During our conversation, I 
explained that the interview was to gather data for a doctoral research project that was being done about the Etobicoke North Community.

For the interview stage of this project, 16 persons were interviewed, including two elected members of the Government of Canada who serve the Etobicoke North Constituency, ten leaders of community organizations in Etobicoke North, and four community members. All of the interviews were conducted between January 10 and September 4, 2013. In keeping with the guidelines for qualitative research using interviews, each interviewee read and signed two copies of the informed consent form (see Appendix A). After the copies were signed, the interviewee was given one copy, and I kept the other confidentially. In addition, no one was allowed to be present or to listen to the interview. I again explained the nature of the research and expressed the hope that the findings from this research would provide the church with useful information that would enable it to become more effective in meeting the needs of the community. Next, the research instrument (see Appendix B) was explained to the interviewees.

It should be noted that the political leaders were contacted first because it was anticipated that they would have a broad knowledge of Etobicoke North. In addition, I felt that these political leaders would have the contact information for community leaders who would be knowledgeable about of the needs of the community. Each interview included an explanation of "needs," so that the interviewees had a clear understanding of the term. Kurtz (2008) indicated, “A need is an imbalance between the consumer’s actual and desired states" (p. 158). Sandhusen (2008) saw "needs" as reflections of situations in which something is physically or mentally lacking (p. 3). He further added, "In more advanced economies, needs become more numerous and arise on different levels. For 
example, needs satisfied by enrolling in a diet program in the United States might simultaneously be functional (to lose weight), psychological (to feel better about your appearance), and social (to attract a mate)” (p. 3). Bradshaw (as cited in Alston \& Bowles, 2003) classified four kinds of needs, for example, normative needs and felt needs. Normative needs are those that are demarcated by a professional or persons in authority, while felt needs are the "wish list" of a "target group” (p. 125).

After the explanation of needs, a copy of the research instrument (see Appendix B) was presented to the interviewees. In it, they were asked to indicate what they perceived as the top 10 real needs and felt needs of Etobicoke North. Since the interview was semi-structured, I asked the interviewees to provide a rationale or reasons for their choices. Their answers were carefully recorded on the research instrument, as well as on additional writing paper. Next, they were asked to rank the needs from 1 to 10 , with 1 being the most important and 10 being the least important.

The approach that was used for identifying and ranking the real needs was also utilized for the felt needs. At the end of each interview, I went over the recorded responses with the interviewee to ascertain the accuracy of what I had written. If there were any inaccuracies or misinterpretations, these were corrected and again reviewed to ensure their accuracy. In writing about the "quality criteria for an interview," Kvale (2007) observed that during the course of the interview, the interviewer should seek to verify his or her understanding of the answers given by the interviewee (p. 80). Next, I asked each interviewee if he/she wanted to comment any further on the information that was presented or discussed. Kvale (2007) stated that "the interviewer must continually make on-the-spot decisions about what to ask and how; which aspect of a subject's 
answer to follow up and which not; which answers to comment and interpret and which not” (p. 81).

After the interviews, the data was analyzed for patterns, similarities, and differences. In addition, the data received from the primary sources were compared to those of the secondary sources to determine the opportunities and threats. The summarized information was then brought to a planning meeting of the Community Ministries Department for strategy development. The following are the top 10 real needs and felt needs that were discovered during the interview: education, food, security, housing, family support, income, recreation, health, housing, and English as a second language.

\section{Strategy Development}

In chapter three, I noted Smith’s (2005) position on the development of a marketing strategy. He indicated that the development of a marketing strategy should involve the identification of the target market and the marketing mix. Drummond et al. (2008) observed that "organizations are primarily making decisions about which markets to operate in and which products/services to offer those markets” (p. 180). Therefore, the results that were compiled from the situation analysis were used to identify the marketing opportunities. Each opportunity was evaluated for its strategic fit. Wrenn et al. (2010) indicated that "a marketing opportunity is an attractive arena of relevant marketing action in which a congregation can apply its strengths to satisfy significant needs of a target group” (p. 316). After the opportunities were identified, the Community Ministries Department decided which segment of the public would be targeted. Drummond et al. (2008) observed that the selection of the segment is a strategic process that requires 
qualitative and creative decisions (p. 188). After selecting the target market, I continued to work with the Community Ministries Department on the development of its marketing strategy.

McDonald (2007) defined marketing strategy as the method through which a company attains its marketing objectives and utilizes the four Ps (p. 298). Wrenn et al. (2010) indicated that for a congregation, the four Ps are

1. Product: ministries, programs, services, and goods

2. Place: locations, atmospherics, and internet

3. Price: psychological costs, social costs, time, and money

4. Promotion: advertising, publicity, telemarketing, direct marketing, and internet (p. 296).

Zeithaml, Bitner, and Gremler (2006) also showed that there are seven Ps in the services marketing mix: product, price, place, promotion, people, physical evidence and process. Wrenn et al. (2010) indicated that a "marketing strategy consists of specifying marketing goals and setting your positioning strategy” (p. 328). Thus, the next step in the methodology was to develop the marketing goals and objectives.

Drummond et al. (2008) noted that there are different conceptions pertaining to the meaning of goals and objectives (p. 140). In this project, a goal is "an observable and measurable end result having one or more objectives to be achieved within a more or less fixed time frame” (Goal, par. 1). In addition, an objective is “a specific result that a person or system aims to achieve within a time frame and with available resources” (Objective, par. 1).

To determine the goals, we reflected on the opportunities that came out of the 
situation analysis and the strengths of the Community Ministries Department. Wrenn et al. (2010) suggested that "an organization should pursue goals, opportunities and strategies that are suggested by, or congruent with, its strengths/resources and avoid those where its resources are insufficient” (pp. 312, 313).

Next, the objectives were constructed from the goals. Withers and Vipperman (2003) observed, "In business, it is essential to communicate more than goals. You must specify when you will do how much of what to achieve the goal, that is set objectives” (p. 87). Hamper (2014) stated, “All objectives should be set within the framework of your environmental analysis in relation to what future product positioning you would like to achieve” (p. 191). He further noted, "No set of objectives in marketing plan should be presented without first stating the assumptions upon which they depend” (p. 192).

Therefore, in order to determine the objectives, the members of the department discussed the following questions:

1. What product/products would it offer to the community?

2. What would be the cost of the product/products to the department?

3. Where and when would the product/products be delivered to the department?

4. What price would the members of the community pay for the product/products?

5. What kinds of promotion would be done to ensure effective marketing?

6. Who would be responsible for the delivery of product/products to the members of the community?

7. What indicator(s) would be used to confirm that the product/products were delivered the members of community? 
8. How would the effectiveness of the delivery and distribution processes be assessed?

The selection and establishment of the objectives for the product (ministries, programs, services, and goods) were made based on the resources available, the needs that were to be addressed, and the assumptions about the relevance of the marketing mix. The objectives for place, price, people, product and promotion were set based on the results of the situation analysis and the assumption relative to each of the 4Ps. Hamper (2014) noted that "assumptions are future operating conditions that will have an impact on your marketing plan” (p. 192). Moore and Pareek (2006) stated that “promotion involves dissemination of information about a product or a company using five different key types of promotion: advertising, sales promotion, public relations, personal selling, and direct marketing” (p. 85).

In arriving at the objectives for promotion, the following assumption was made: If the five key types of promotion are adopted, more people from the community will attend the Community Ministries Department's events. In addition, the department would be able to serve more of the community's poor and hurting in Christ's name. Sahlin et al. (1994) stated, "The purpose of the Adventist Community Services (ACS) network can be stated very simply: to serve the poor and hurting in Christ's name” (p. 13). After the assumptions were made, the objectives were set for the promotion component of the strategic marketing plan.

The next task was to implement the strategic marketing plan and assess the performance. A detailed description of the design and implementation of the strategic marketing plan can be found in chapter five, along with an outline of the plan. 


\section{Implementation and Control}

Goetsch 1993 (as cited in Kotler \& Keller 2006) stated, “Marketing implementation is the process that turns marketing plans into action assignments and ensures that such assignments are executed in a manner that accomplishes the plans and stated objectives” (p. 715). Drummond et al. (2008) stated that control should be measurable and should compare what is expected with the actual outcome. In addition, it entails taking the necessary actions to protect the strategic plan once it is implemented.

In this project, the system of control included a registration booth for all community attendees. Upon arrival, attendees were guided to this booth where they filled out a registration form (see Appendix C) before they were allowed to proceed into the Day of Love and Care program.

After the implementation and control of the strategic plan, the data from the registration forms were extracted

1. To determine the number of attendees from the community,

2. To compare the community attendance, before and after the development and implementation of the strategic marketing plan, and

3. To ascertain which method of promotion was most effective in reaching the attendees.

The results and analysis of the data from the registration forms are documented in chapter five.

\section{Conclusion}

In this project, the qualitative method of study was used to help develop and implement a strategic marketing plan for the Toronto West Seventh-day Adventist 
Church Community Services Department. It required the performance of a marketing research to determine the needs of the community and the opportunities and threats for the church. The primary data was collected through 16 interviews and the secondary data was amassed from relevant websites and printed documents about Canada, Toronto, and Etobicoke North. The combined information was then used to develop the goals and objectives of the strategic marketing plan. After the plan was developed, it was implemented, controlled, and evaluated to determine its effectiveness. 


\section{CHAPTER 5}

\section{THE RESULTS}

\section{Introduction}

The purpose of this project was to develop and implement a strategic marketing plan for the Community Services Department at Toronto West Seventh-day Adventist Church. Many researchers have proposed various components, but most included the situation analysis, strategy development, and implementation as basic ingredients of the strategic marketing planning process. Some have also included the element of control as an important aspect of the strategic marketing plan. This chapter will address the development and implementation of the four aspects of the strategic marketing plan and results of the plan.

\section{Situation Analysis and its Results}

The analysis in this research was conducted using the qualitative approach. In writing about marketing research, Wrenn, Kotler, and Shawchuck (2010) stated that qualitative research is not only necessary, it is sometimes the only type of research religious organizations can do because of their resources (p. 126). They stated that the distinctive uses of qualitative research are to

1. Probe deeply into consumers' underlying needs, perceptions, preferences, and satisfaction. 
2. Gain greater familiarity and understanding of marketing problems of unknown cause.

3. Develop ideas that can further be investigated through quantitative research (p. 126).

The strategic planning tool, which was utilized during the research, was a SWOT analysis. Kurtz (2008) noted that SWOT is a strategic planning instrument that is used to help an organisation compare its strengths and weaknesses with its opportunities and threats.

\section{Strengths and Weaknesses}

In order to determine the strengths and weaknesses of the Community Services Department, the records of the departmental operations from 2005 to 2012 were analyzed. In addition, an inventory was conducted on its resources and current operations. The information gleaned from this analysis served as an important source for discussions surrounding the strengths and weaknesses of the department. At the end of the discussions, the following were deemed as strengths: a good inventory of food and clothing, an adequate volunteer staff, and its location at the intersection of two major roads. The department's weaknesses were (a) insufficient finances to meet its budgetary needs, and (b) the absence of valid information pertaining to the needs of the community it serves.

\section{Opportunities and Threats}

The opportunities and threats were determined via an analysis of the external environment. The analysis was done by marketing research on primary and secondary 
sources. Kurtz (2008) noted that in the area of marketing research, various questions about marketing can be answered by combining information from primary and secondary sources. The secondary sources used in this research included the websites of the City of Toronto, the Government of Canada, businesses, and published materials.

As mentioned in Chapter 4, the primary sources came from semi-structured interviews that were conducted on 16 individuals from the community. The semistructured interviews were done as part of the situation analysis to ascertain the needs of the community. Day (1990) noted that the primary purposes of organizations that function from a marketing perspective is to discover the wants and needs of the selected markets. Kotler and Keller (2006) indicated, marketers should know the selected markets. By knowing the needs of the community, the Community Ministries Department was able to discover its opportunities.

The composition of the 16 interviewees included two elected Government of Canada officials who serve in the Etobicoke North Constituency, 10 leaders from different community organizations within Etobicoke North, and four community members. All of the interviews were done between January 10 and September 4, 2013. Interviewees were asked to sign an informed consent letter before beginning the interview. Seven of the interviews were conducted at the respective office of each interviewee and the other nine interviews were conducted at the church. Each interview lasted between one and two hours and was conducted in a private setting at a scheduled time that I had previously arranged.

With respect to conducting the interview, I explained the research document, including the concepts of needs: real needs and felt needs. Onyenemezu and Olumati 
(2013) noted that felt-needs is a fundamental idea in community development. Felt needs are things the community believes should be changed in order to take care of a deficit in the community. Sahlin (2004), in referring to the concerns of local church leaders, said that they requested help to determine and speak to their communities felt needs (p. I). In this research, felt needs is used to mean the needs of a community that are felt by a section or several sections of the community. Kotler and Keller (2006) believed that Real needs are the things the customer really wants.

Hence, real needs are defined as needs of the individual. These needs may also be felt needs if they are felt across a demographic region. After the interviewee completed the research document (see Appendix B), an explanation about each felt need and real need listed was solicited. The responses were carefully recorded on paper in the presence of the interviewee. To confirm the written document, the information recorded was read back to the interviewee at the end of each interview. This was done to ensure that the responses were correctly documented and properly understood. Any additional comments that were made during this time of clarification were also documented and clarified. A copy of the signed consent form was given to the interviewee and a copy was keep by the interviewer.

\section{Results of the Situation Analysis}

From the interviews the following real needs and felt needs were identified as the top 10 of the Etobicoke North Community based on the number of persons who listed them. The interviewees were also asked to rank the real needs and felt needs. Tables 1 and 2 reveal the top 10 real needs and felt needs of Etobicoke North Community, based on the number of interviewees who listed them. 
Table 1

Top 10 Real Needs of Etobicoke North Based on Number of Persons Listing Them $(N=16)$

\begin{tabular}{|c|c|}
\hline Real Needs & Frequency \\
\hline Employment & 13 \\
\hline Security & 13 \\
\hline Food & 12 \\
\hline Housing & 12 \\
\hline Family Support & 11 \\
\hline Income & 10 \\
\hline Education & 9 \\
\hline Recreation & 9 \\
\hline Health & 9 \\
\hline $\begin{array}{c}\text { English as a Second } \\
\text { Language }\end{array}$ & 6 \\
\hline
\end{tabular}

Table 2

Top 10 Felt Needs of Etobicoke North Based on Number of Persons Listing Them $(N=16)$

\begin{tabular}{|c|c|}
\hline Felt Needs & Frequency \\
\hline Security & 15 \\
\hline Income & 14 \\
\hline Education & 14 \\
\hline Food & 13 \\
\hline Employment & 13 \\
\hline Family support & 13 \\
\hline Health & 12 \\
\hline $\begin{array}{c}\text { English as a second } \\
\text { language }\end{array}$ & 11 \\
\hline Housing & 10 \\
\hline Recreation & 10 \\
\hline
\end{tabular}


As part of the interviews, the interviewees were also asked to rank their top 10 real needs and felt needs. Tables 3 and 4 provide the results of the frequency ranking and calculated scores for items under real needs and felt needs.

Table 3

Frequency Ranking and Calculated Scores for Items Under Real Needs $(N=16)$

\begin{tabular}{|c|c|c|c|c|c|c|c|c|c|c|c|}
\hline \multirow{2}{*}{$\begin{array}{c}\text { Real } \\
\text { Needs }\end{array}$} & \multicolumn{11}{|c|}{ Frequency Ranking } \\
\hline & 1 & 2 & 3 & 4 & 5 & 6 & 7 & 8 & 9 & 10 & SCORE \\
\hline Food & $\begin{array}{l}+++ \\
(30)\end{array}$ & $\begin{array}{c}+ \\
(9)\end{array}$ & $\begin{array}{c}+ \\
(8)\end{array}$ & $\begin{array}{c}+ \\
(7)\end{array}$ & & $\begin{array}{c}+ \\
(5)\end{array}$ & $\begin{array}{c}+ \\
(4)\end{array}$ & $\begin{array}{l}++ \\
\text { (6) }\end{array}$ & $\begin{array}{l}++ \\
(4)\end{array}$ & & 73 \\
\hline $\begin{array}{c}\text { Employ } \\
\text { Ment }\end{array}$ & & $\begin{array}{l}+++ \\
(27)\end{array}$ & $\begin{array}{l}+++ \\
(24)\end{array}$ & $\begin{array}{c}+ \\
(7)\end{array}$ & $\begin{array}{l}+++ \\
\text { (18) }\end{array}$ & & & $\begin{array}{c}+ \\
\text { (3) }\end{array}$ & & $\begin{array}{c}+++ \\
(9)\end{array}$ & 88 \\
\hline Recreation & $\begin{array}{c}+ \\
(10)\end{array}$ & & & $\begin{array}{c}+ \\
(7)\end{array}$ & $\begin{array}{c}+ \\
(6)\end{array}$ & $\begin{array}{l}+++ \\
(15)\end{array}$ & & $\begin{array}{l}++ \\
(6)\end{array}$ & $\begin{array}{l}+ \\
(2)\end{array}$ & & 46 \\
\hline $\begin{array}{l}\text { Family } \\
\text { support }\end{array}$ & & $\begin{array}{c}++ \\
(18)\end{array}$ & $\begin{array}{l}+++ \\
(24)\end{array}$ & $\begin{array}{c}+ \\
(7)\end{array}$ & $\begin{array}{c}++ \\
(12)\end{array}$ & & $\begin{array}{l}+ \\
(4)\end{array}$ & $\begin{array}{c}+++ \\
(9)\end{array}$ & & & 74 \\
\hline Education & & $\begin{array}{l}+++ \\
(27)\end{array}$ & & $\begin{array}{c}++ \\
(14)\end{array}$ & & $\begin{array}{l}+++ \\
(15)\end{array}$ & & & & $\begin{array}{c}+ \\
(1)\end{array}$ & 57 \\
\hline Income & $\begin{array}{c}+ \\
(10)\end{array}$ & $\begin{array}{c}+++ \\
++ \\
(45)\end{array}$ & $\begin{array}{c}+ \\
(8)\end{array}$ & $\begin{array}{c}+ \\
(7)\end{array}$ & & $\begin{array}{c}+ \\
(5)\end{array}$ & $\begin{array}{c}+ \\
(4)\end{array}$ & & & & 79 \\
\hline Housing & $\begin{array}{l}+++ \\
(30)\end{array}$ & $\begin{array}{c}++ \\
(18)\end{array}$ & & $\begin{array}{c}++ \\
(14)\end{array}$ & & $\begin{array}{c}++ \\
(10)\end{array}$ & & $\begin{array}{c}+++ \\
\text { (9) }\end{array}$ & & & 81 \\
\hline Security & $\begin{array}{c}++++ \\
++ \\
(60)\end{array}$ & $\begin{array}{c}+ \\
(9)\end{array}$ & $\begin{array}{c}+ \\
(8)\end{array}$ & & $\begin{array}{c}+ \\
(6)\end{array}$ & & $\begin{array}{c}+ \\
(4)\end{array}$ & $\begin{array}{c}+ \\
\text { (3) }\end{array}$ & $\begin{array}{l}++ \\
(4)\end{array}$ & & 94 \\
\hline Health & & & & & $\begin{array}{c}+ \\
(6)\end{array}$ & $\begin{array}{l}+++ \\
(15)\end{array}$ & $\begin{array}{c}++ \\
++ \\
(20)\end{array}$ & & & & 41 \\
\hline $\begin{array}{l}\text { English as } \\
\text { 2nd } \\
\text { language }\end{array}$ & & $\begin{array}{l}+ \\
(9)\end{array}$ & $\begin{array}{c}++ \\
(16)\end{array}$ & & $\begin{array}{l}+++ \\
(18)\end{array}$ & & & & & & 43 \\
\hline
\end{tabular}

Note. + - Denotes assigned ranking of respondent () - Denotes calculated score for the frequency in the cell. Rank and Assigned Score: 1 - 10; 2 - 9; 3-8; 4-7; 5 - 6; 6 - 5; 7 $-4 ; 8-3 ; 9-2 ; 10-1$ 
Table 4

Frequency Ranking and Calculated Scores for Items Under Felt Needs $(N=16)$

\begin{tabular}{|c|c|c|c|c|c|c|c|c|c|c|c|}
\hline \multirow{2}{*}{ Felt Needs } & \multicolumn{11}{|c|}{ Frequency Ranking } \\
\hline & 1 & 2 & 3 & 4 & 5 & 6 & 7 & 8 & 9 & 10 & SCORE \\
\hline Food & $\begin{array}{c}+ \\
(10)\end{array}$ & & $\begin{array}{c}++ \\
(16)\end{array}$ & & & $\begin{array}{c}+ \\
(5)\end{array}$ & 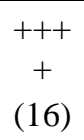 & $\begin{array}{c}+++ \\
(9)\end{array}$ & $\begin{array}{l}++ \\
\text { (4) }\end{array}$ & & 60 \\
\hline $\begin{array}{c}\text { Employ } \\
\text { Ment }\end{array}$ & $\begin{array}{c}++ \\
(20)\end{array}$ & $\begin{array}{c}++++ \\
++++ \\
(72)\end{array}$ & $\begin{array}{l}+++ \\
(24)\end{array}$ & & & & & & & & 116 \\
\hline Recreation & & $\begin{array}{l}+++ \\
(27)\end{array}$ & $\begin{array}{c}+ \\
(8)\end{array}$ & $\begin{array}{c}++ \\
(14)\end{array}$ & & & $\begin{array}{l}+++ \\
(12)\end{array}$ & $\begin{array}{c}+ \\
(3)\end{array}$ & & & 64 \\
\hline $\begin{array}{l}\text { Family } \\
\text { support }\end{array}$ & $\begin{array}{c}+ \\
(10)\end{array}$ & $\begin{array}{l}+++ \\
(27)\end{array}$ & $\begin{array}{l}+ \\
(8)\end{array}$ & $\begin{array}{c}+++ \\
+ \\
(28)\end{array}$ & & $\begin{array}{l}+++ \\
(15)\end{array}$ & $\begin{array}{c}+ \\
(4)\end{array}$ & & & & 92 \\
\hline Education & & & $\begin{array}{l}\text { +++ } \\
+++ \\
(48)\end{array}$ & $\begin{array}{c}++ \\
(14)\end{array}$ & $\begin{array}{c}++ \\
(12)\end{array}$ & & & 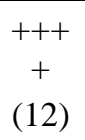 & & & 86 \\
\hline Income & $\begin{array}{c}++ \\
(20)\end{array}$ & $\begin{array}{l}+++ \\
(27)\end{array}$ & & $\begin{array}{c}++ \\
(14)\end{array}$ & $\begin{array}{l}+++ \\
(18)\end{array}$ & & $\begin{array}{l}++ \\
(8)\end{array}$ & & $\begin{array}{l}+ \\
\text { (2) }\end{array}$ & $\begin{array}{c}+ \\
(1)\end{array}$ & 90 \\
\hline Housing & $\begin{array}{c}+++ \\
+ \\
(40)\end{array}$ & $\begin{array}{l}+ \\
\text { (9) }\end{array}$ & & $\begin{array}{c}++ \\
(14)\end{array}$ & $\begin{array}{c}++ \\
(12)\end{array}$ & & & $\begin{array}{c}+ \\
\text { (3) }\end{array}$ & & & 78 \\
\hline Security & 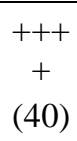 & & & $\begin{array}{c}++ \\
+ \\
(28)\end{array}$ & 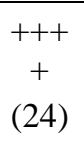 & & $\begin{array}{c}+ \\
(4)\end{array}$ & & $\begin{array}{l}++ \\
\text { (4) }\end{array}$ & & 100 \\
\hline Health & & & & $\begin{array}{l}+ \\
(7)\end{array}$ & $\begin{array}{c}+ \\
(6)\end{array}$ & $\begin{array}{c}+++ \\
+++ \\
++ \\
(40)\end{array}$ & & & $\begin{array}{l}++ \\
\text { (4) }\end{array}$ & & 57 \\
\hline $\begin{array}{l}\text { English as } \\
\text { 2nd } \\
\text { language }\end{array}$ & $\begin{array}{c}+ \\
(10)\end{array}$ & $\begin{array}{c}+++ \\
+ \\
(36)\end{array}$ & & & $\begin{array}{c}++ \\
+ \\
(24)\end{array}$ & & & & $\begin{array}{l}++ \\
\text { (4) }\end{array}$ & $\begin{array}{c}+ \\
(1)\end{array}$ & 75 \\
\hline
\end{tabular}

Note. + - Denotes assigned ranking of respondent. () - Denotes calculated score for the frequency in the cell. Rank and Assigned Score: 1 - 10; 2 - 9; 3-8; 4- 7; 5 - 6; 6 - 5; 7 -4; 8 - 3; 9 - 2; $10-1$

The ranking scores were calculated by attaching a numeric value to the ranking 110. For example, the rank of \#1 was considered to be the highest need by the interviewee and so it was scored as 10; the rank of \#10 was given a score of 1 , since it was considered 
to be the lowest need. The total number of interviewees was 16 and is represented as $N$. An analysis of the listings of the ten top real needs and felt needs of Etobicoke North as indicated in the interviews shows that areas of real needs and felt needs are the same. However, the \# 1 real need was education and the \# 1 felt need was security. With regards to the ranking of the needs, security was ranked as \# 1 for the real needs and employment was ranked as the \# 1 for the felt needs.

In addition, the secondary sources that I examined support the findings of this research in terms of real needs and felt needs in the Etobicoke North area. In a community snapshot of North Etobicoke, Nayar (2010) noted, "In general the snapshot points to a rapidly changing immigrant community in North Etobicoke. In fact more new immigrants are settling in North Etobicoke (24.4\%) than across the city of Toronto (21.6\%)” (p. 2). Thus, North Etobicoke is a changing community. In addition, it is a community with high levels of poverty and unemployment rate. Nayar (2010) stated, "Recent immigrants experience much higher levels of poverty than others in North Etobicoke (30.5\% versus 20.1\%)” (p. 2). The same author also observed that "unemployment is highest for recent immigrants (10.3\%), versus $7.95 \%$ for visible minorities and $7.2 \%$ for the total population” (p. 2).

In its annual report for 2012, the Daily Bread Food Bank report on the Greater Toronto Area stated, "1,123,500 visits were made to the GTA food banks. This was an increase of $18 \%$ or over 170,000 since the pre-recession period in 2008 ” (p. 6). They observed that the "key driving forces behind the changing face of hunger in the GTA are poverty and lack of income” (p. 22). In addition, the same report stated, "for every one person who comes to a food bank, there is at least one other person who cannot afford 
food and is struggling with hunger who does not come” (p. 10).

\section{Poverty and Needs}

In their research on Toronto, MacDonnell, Robinson, Mikadze, McDonough, and Meisner (2011) showed that in 2006, families who lived in high-rise rented units in Etobicoke experienced a rate of poverty of 35\% (p. 8). Etobicoke North is an area of the city of Toronto with many high-rise apartment buildings. In addition, a map of the North Etobicoke area from the same study showed that $40 \%$ of the families were categorized as low-income families in 2006. They also noted that in their study, "one quarter of the tenants interviewed say they do without things they need every month in order to pay the rent” (p. 9). Hulchanski (2007) found that during a period of 35 years from 1970 to 2005, the average individual income of North Etobicoke relative to the rest of Toronto average income declined by $20 \%$ or more (p. 7). In addition, in his 20-year prediction for 2005 to 2025 based on the trends of the past 35 years, Hulchanski (2007) noted that, "neighbourhoods in city number 3 which includes Etobicoke North will increasingly attract especially low-income immigrants who cannot afford housing in the inner city or outer suburbs” (pp. 27, 28).

Hurtig (1999) quoted Gro Harlem Bruntland, the three-time prime minister of Norway, as saying, "Poverty is lack of opportunity, lack of freedom. It is hunger and malnutrition, disease and lack of social services.... Poverty is the gravest insult to human dignity. Poverty is the scar on humanity’s face” (p. 8). Claerbaut (2005) stated, "In spite of the many poverty myths, poverty means much more than absence of money. It is powerlessness and alienation from the key institutions of society” (p. 86). Albanese (2009) observed that "in response to the question, what is poverty? Canadian children in 
grades 4 and 5 list, not having breakfast sometimes, (and) sometimes it is hard because my mom gets scared and she cries, amongst their answers” (pp. xvii, xviii).

North Etobicoke is becoming an immigrant community with high unemployment and poverty. Being an immigrant community also creates the need for English as a second language. According to Nayar (2010), "In forty-two percent of North Etobicoke homes, English is not the predominant language, as compared to thirty-two percent for the city overall” (p. 11).

In addition, Bethune and Wang (2010) in the North Etobicoke Local Immigration Partnership Highlights of Consultations and Surveys report on the focus groups' meetings which included input from 147 North Etobicoke residents stated, "Settlement, Transportation, Health Care, Food Bank And Clothing Drive, Language Training, Education, Employment” (p. 5) are the settlement needs of newcomers. The same report also cited consultations that involved 120 residents. In it, the issues that needed to be addressed were prioritized:

Employment, Health Services, Safety and Security, Affordable Housing, Language Training, Senior Service, Child/Youth Programs/Services, Accessible Support Services (i.e. Child Care, Transportation), Community Gatherings, More/Improved Community Services, Financial Assistance, Public Awareness, and Recreation. (p. 7)

Ogilvie (2012), in a report on diabetes, also indicated, "Massive new study finds half of Ontario’s 1 million cases in the GTA with ethnicity a major factor” (p. 1). He further noted, "In Brampton, Melton, and Rexdale; for example, between 12 and 22 of every 100 adults have diabetes. The provincial rate is about 9 cases for every 100 adults” (p. 1). Rexdale is one of the neighborhoods of North Etobicoke.

Thompson et al. (2008) stated, 
The two most import parts of the SWOT are drawing conclusions from the SWOT .. . about the company's . . . situation, and translating these conclusions into strategic actions to better match the company's resource strengths and market opportunities ... and to defend against external threats. (p. 109)

The analysis of the external environment shows that new immigrants are continuing to arrive in North Etobicoke. These have many needs that are unmet. Therefore, the opportunity available to the Community Services Department is to minister to these ten real and felt needs. The perceived threat to the department was the Moslem mosques, Sikhs temples, and Hindu temples in North Etobicoke. These facilities were already reaching out to the community by providing food. However, despite their presence and activity, there is still an opportunity for the Community Services Department to make its contribution towards meeting the needs of the community that carry a strategic fit with the resources of the department.

\section{Strategy Development and its Results}

The results from the SWOT analysis were used to develop the strategic marketing plan for the department. This plan entailed marketing to the needs of the community through the annual Day of Love and Care program. Thompson et al. (2008) stated that, “a company's strategy is the management's action plan for running the business and conducting operations” (p. 3). E. G. White (1905) stated,

Christ's method alone will give true success in reaching the people. The Saviour mingled with men as one who desired their good. He showed His sympathy for them, ministered to their needs, and won their confidence. Then He bade them, "Follow Me.” (p. 143)

This suggests that part of Jesus' mission strategy of seeking and saving the lost is needs identification and analysis. Sahlin (2004), in commenting on this quotation, observed, “To 'minister to their needs,' is as clear a mandate as possible for understanding and 
responding to the needs in the community” (p. iii). E. G. White (1946) stated, “God will have men who will venture anything and everything to save souls” (p. 63). E. G. White (1948) also indicated, “The work of gathering the needy, the oppressed, the suffering the destitute, is the very work which every church should long since have been doing” (p. 276). In a recent work, Wrenn, Hoover, and Warwick (2013) observed that "throughout time we have been striving to satisfy our own needs. Yet we should also look to serving the needs of others which is a mandate frequently mentioned in the Bible” (marketing and needs, section 1, para 1). Wrenn (2011) noted,

Marketing is about focusing on the needs of other, and religious marketers are called to do just that. But in the hands of church leaders marketing can and should be more than transactional, it must be transformational- getting people to look beyond themselves and become committed to the life of Christian service. (p. 52)

As a result, the leaders of the department discussed the use of marketing strategy to reach the community in order to minster to the needs that were discovered by the SWOT analysis. To begin, the leader of the department suggested a mission statement for the department .As mentioned in chapter 4, this suggestion was made at an early stage in the planning and was not used initially. The mission statement of the church had been used to begin the planning process. When the situation analysis was complete, the top 10 real needs and felt needs of the community were compared with the departmental strengths of having an adequate supply of food and clothing and enough volunteers. From this comparison, it was concluded that all of the needs of the community could not be adequately met on the Day of Love and Care. Thus, it was decided that the department would meet the community's needs for food, clothing, recreation, health, and education. Clothing was chosen because it was included in the need for family support. Therefore, 
the products for the Day of Love and Care would be food, clothing, recreation, health services, and loving services.

In addition, based on the SWOT analysis, the issue of poverty was given great consideration in planning for the day. In the past, there had been a price attached to some of the products, so faced with the knowledge and understanding that many people in the community might not be able to pay for the products, the leaders agreed that they would be offered to the community free of charge. The decision was also made to host the program at the church.

Armstrong et al. (2007) indicated that the four Ps of marketing are "product, price, place and promotion” (p. 19). By late July, 2013, the department had decided upon three of the four Ps for the program.

These were

1. Place - Church building and compound

2. Product - food, clothing, health services, educational literature, and recreation

3. Price - free

Following these discussions, the department developed the following goal for the program: To use marketing strategy to improve the attendance of the community at the annual Day of Love and Care.

Next, the department explored ways to achieve the set goals. First, because the department's intention was to reach more than the 35 persons based on the previous year's attendance, they looked for ways to provide more food. This included soliciting donations from supermarkets, purchasing food, and collecting food from the Government of Canada Depot. Second, as part of the marketing plan, the department chose to 
advertise via radio, newspaper, flyers, lawn signs, posters, and word-of-mouth. Arndt (as cited in East, Wright, \& Vanhuele, 2008) stated that, "word of mouth is product-related, oral, person-to-person communication” (p. 243).

Thus, the final P of the four Ps—promotion — was to include radio, newspaper, flyers, lawn signs, posters, and word of mouth. It addition, the department changed the name of the program from the "Day of Love and Care" to Our Community Day. The advertisement on the flyer was to include the venue, the products, and the words "Experience the love on Our Community Day."

Because of the weaknesses of the department in not having adequate resources to address some of the needs, a decision was made to partner with two community businesses to provide services to address some of the prevalent health needs of the community. The goals for the community day were discussed and the following objectives were determined:

1. To reach 250 persons from the community for the Community Day

2. To acquire enough food for 250 persons

3. To source 50 volunteers

4. To partner with businesses to address some of the health needs of the community

5. To advertise as widely as possible by September 15, 2013

6. To minister to the health, educational, food, and recreational needs of the community

In order to achieve these objectives, the church contributed $\$ 2,965.00$. Two individuals within the department contributed $\$ 900.00$ bringing the total to $\$ 3,865.00$. 


\section{Results of Strategy Development}

Wrenn et al. (2010) included in their marketing plan the following in sequential order: “mission statement, situation analysis, target market, marketing strategy, design and implement marketing tactics, marketing budget, and marketing control” (pp. 308,309). Westwood (2006) included in his marketing plan the following: “executive summary, situation analysis, marketing objectives, marketing strategies, schedules, sales promotion, budgets and profits and loss account, control and update features” (p. 108). In the creation of the strategic marketing plan for the community day, I incorporated elements from both Wrenn et al. (2010) and Westwood (2006).

\section{Strategic Marketing Plan for Community Ministries}

\section{Introduction}

Over the past 12 years, the Community Services Department has tried to reach the community of North Etobicoke without the expected response from the community. In addition, over the past two years, the department has introduced a program called "The Day of Love and Care" to increase the possibilities of getting a better response from the community. In 2011, the responses to the program were poor and in 2012, only 35 persons attended the program. As a result, I thought that a strategic marketing plan might allow the department to be more successful in its search for reaching the residents of Etobicoke North. Because Wrenn et al (2010) and Westwood (2006) began their marketing plan with a mission statement. I thought that the mission statement that had been suggested at the start of the process was relevant to the final design and implementation of the plan. This original suggestion was used as a mission statement when writing up the plan. 


\section{Mission Statement}

To meet to the needs of people in the Etobicoke North Community

\section{Executive Summary}

Even though the previous programs did not achieve the anticipated level of success, it was believed the program could succeed if the reasons why it did not succeed were understood and adjustments were made based on new information. The aim of the strategic marketing plan is to increase the attendance from the 35 persons in 2012 to 250 in 2013.

\section{Situation Analysis}

North Etobicoke is a changing community with many new immigrants. Research done on this area indicates that it has high rates of poverty, unemployment, and diabetes. In addition, it has high rates of non-English languages spoken in the homes. Based on the research conducted, the strengths of the Toronto West Community Services Department can be used to meet some of the needs of the community. Therefore, the Community Day program would be an opportunity to provide for some of the needs of the community.

5. Target Market

The target market includes the poor, the unemployed, and recent immigrants of North Etobicoke.

6. Marketing Strategy

I. Goal: To use marketing strategy to improve the attendance of the community at the annual Community Day.

II. Objectives

a) To advertise widely from July to September 15, 2013 using radio, 
newspaper, lawn signs, flyers, posters, and word-of-mouth.

b) To distribute flyers and posters through church members, community business places, and community centers by September 15, 2013.

c) To provide all products free of charge to the community.

d) To invite two businesses from the community to address some of the health needs of the community.

III. Assumptions

a) North Etobicoke will continue to be a changing community.

b) The rate of poverty and unemployment for new immigrants will remain high.

c) The weather will be good on the day of the program.

d) The volunteers and staff will perform well.

7. Key Products

a) Cooked food that is ethnically sensitive.

b) Groceries including basic necessities such as rice, sugar, flour, cooking oil, canned beans, and crackers.

c) Food vouchers.

d) Clothing (new and used).

e) Health presentations on diabetes, hypertension, and dental care.

f) Blood pressure checks.

g) Recreation, which includes a bouncy castle for children, drill displays by the Pathfinders, and soft Christian music. 


\section{Key Services Area}

The church compound, social hall, and kitchen

\begin{tabular}{llrl} 
Income & Church Contribution & $\$ 2,695.00$ & \\
\multirow{2}{*}{ Expenditures } & From Donations & $\underline{900.00}$ & \\
& & & $\$ 3,865.00$ \\
& Rental of Equipment & $\$ 400.00$ & \\
& Transportation of & 200.00 & \\
& Food & & \\
& Advertising & $1,400.00$ & \\
& Purchase of & $1,785.00$ & \\
& Groceries & & \\
& Donation for Food & $\underline{80.00}$ & \\
& & & $\$ 3,865.00$ \\
Total Gain/Loss & & & $\$ 0,000.00$
\end{tabular}

The strategic marketing plan was implemented on September 15, 2013 at the Community Day that was held on the premises of the church.

\section{Implementation, Control, and Results}

In terms of implementation, boxes of groceries were prepared three days before the Community Day. A bouncy castle and five tents were erected on the church lawns and parking lot on the morning of the program. Two of the tents housed free services offered by the community businesses. These included free blood pressure checks and presentations. The third tent was used as a distribution center for the pre-packed boxes. The fourth tent housed programs and entertainment for the children and the last tent was used for registration for visitors. Control was maintained via the registration process. Each visitor or visiting family was asked to register as they entered the church 
compound. In addition, Dr. Kirsty Duncan, the Member of Parliament, declared the program open at 12:00 p.m.

The Pathfinders provided entertainment for the visitors in the parking lot by carrying out two drill displays. Christian music was played in the background during most of the program while health professionals did three health presentations on diabetes, hypertension, and dental care for two groups of 30 persons.

To the surprise of the staff, people from the community started arriving for the program by 10:00 a.m. This had never happened before. The planned goal of reaching 250 people was met-300 adults and 75 children attended the program. By 4:00 p.m., the supply of cooked food and groceries had being exhausted and people were still arriving. The program came to a close at 5:00 p.m. with a record of 145 registrations and a total head count of 375. The discrepancy between the total number of people who attended and those registered was that many of the people were of Far Eastern and Middle Eastern background, and this meant that only the head of the family would register. In addition, the volunteers responsible for the registration ran out of forms.

Table 5 shows the type of promotion, as indicated on the registration form, by which the visitors learned about the program.

It could be seen that the strategic marketing plan did improve the responses of the community to the Community Day. Historically, the highest attendance of visitors at a Community Day hosted by the Community Services Department was 35. In addition, the forms of promotion that the community responded to most were lawn signs/flyers and word-of-mouth advertising through friends. Of the 145 persons who filled out registration forms, only 114 forms had valid data representing 78.6\% of responses. Thirty-one forms 
did not have valid responses, representing $21.4 \%$ of the responses. Since the actual attendance was 300 adults plus 75 children, there was a significant improvement as compared with previous years. As a matter of fact, based on the registration forms there was more than a 300\% increase in attendance. Based on the numbers counted, there was over a 700\% increase in attendance.

Table 5

Ways People Learned About the Program

\begin{tabular}{|l|c|c|}
\hline \multicolumn{1}{|c|}{ Responses $\mathbf{N = 1 1 4}$} & Frequency & Valid \% \\
\hline Flyers/lawn signs & 53 & 46.5 \\
\hline Radio & & \\
\hline Newspapers & 1 & 0.9 \\
\hline Friend & 13 & 41.2 \\
\hline Other & 114 & 99.9 \\
\hline Total & & \\
\hline
\end{tabular}

\section{Conclusion}

The results of the development and implementation of the strategic marketing plan for the Community Services Department at Toronto West Seventh-day Adventist Church indicate that the 10 top real and felt needs are the same. By utilizing the strengths of the Community Services Department to address some of these needs at a Community Day program, coupled with a marking plan, the responses of people from the community were significantly higher than the previous year. Through this research project, the 
Toronto West Seventh-day Adventist Church Community Services Department was

indeed able to sift through the available market opportunities and develop a strategy that was most attractive and suited to the church’s circumstances. 


\section{CHAPTER 6}

\section{SUMMARY, CONCLUSIONS, AND RECOMMENDATIONS}

\section{Summary and Conclusions}

This project document outlines the process of developing and implementing a strategic marketing plan for community ministries at Toronto West Seventh-day Adventist Church in Toronto, Ontario, Canada. I hope that the process that was utilized and the lessons learned might help other churches reach people in their communities.

Chapter 1 describes the background and purpose of the study. In addition, the statement of the problem, the expectations, and an overview of the dissertation project involving the church and the community it serves was presented. Chapter 2 focuses on the biblical and theological foundations of community services in order to provide a possible theology for serving the needy in the neighbourhood of the church. In it, I explore a study of God's nature, and character as it relates to serving the poor and broken-hearted in Jesus' name. This is done by looking at God's perspectives of ministering to the socioeconomically disadvantaged in the Old and New Testaments. In the New Testament, I looked at the legacy of the ministry and teaching of Jesus regarding this subject. In addition, I studied the legacy of the disciples regarding this type of ministry. Further, selected references from the writings of Ellen G. White were used to get guidance as they relate to community services to the needy.

In Chapter 3, I did a review of literature relating to works published about 
strategic market planning between 2000 and 2013 for businesses and churches. Although this is not an exhaustive review of literature on the subject, four aspects of strategic market planning that are critical to this project are reviewed: (a) definitions of marketing, strategic marketing and strategic market planning, (b) the strategic marketing planning process: an overview, (c) marketing for churches, and (d) strategic marketing for churches

In Chapter 4, there is a description of the methodology of the development and implementation of the strategic marketing plan for the Community Services Department of the Toronto West Seventh-day Adventist Church. Three aspects of the strategic planning process are discussed: (a) the analysis of the situation, (b) the development of the marketing strategy, and (c) the implementation and control of the strategy. Chapter 5, focused on the results of the development and implementation of the strategic marketing plan at Toronto West Seventh-day Church. There are also highlights on the results of the situation analysis, the development of the strategy, and the implementation and control of the plan. In this final chapter, I present the summary along with the conclusions and recommendations.

The Bible and the writings of Ellen G. White portray God as a loving, merciful, and compassionate person. God is also portrayed as a plurality of beings—Father, Son, and Holy Spirit—in a loving relationship with each other. Consistent with this portrayal of God's nature, God made man in his own image and likeness. The image is both representative and representational. Therefore, man was made to love and to have relationships with God, fellow human beings, and the created order. The fall damaged man's capacity to be both representative and representational of God. 
Due to his nature, the very day of the fall, God announced to Adam and Eve that he had created a mission to rescue and restore mankind. This mission is predicated on God's love. It includes a revelation of love, compassion, and mercy for all of mankind. Part of the revelation of love for all believers includes caring for the socioeconomically disadvantaged. This caring for the socioeconomically disadvantaged is revealed in the lives of faithful believers in the Old Testament, the laws and reminders given to the Old Testament Church, the mission of Jesus, and the activities of the New Testament Church.

The basis for this revelation of love was given to Israel in two commandments that they were to obey: Thou shall love the lord thy God with all thine heart, and thou shall love thy neighbour as thyself. Jesus noted, "The entire law and all the demands of the prophets are based on these two commandments” (Matt 22:24 NLT). As a result, all the laws that were given to Israel regarding care for the socially disadvantaged were built on love. The mission of Israel included observing these laws. By following these two laws, Israel would have shown God's love for the poor, needy, orphans, and aliens in Israel. In addition, they would have become the most prosperous nation on earth. Their prosperity, and hence their quality of life, would have led people to enquire about God. Thus Israel's mission was to be the people of God. They were to be people who loved the Lord with all their hearts, and their neighbors as themselves. As a result, by studying God's stipulations to Israel concerning ministry to the socioeconomically disadvantaged, one can discover some principles about caring for the needy. These principles are part of the legacy of the Old Testament about caring for the socioeconomically disadvantaged.

In the New Testament, the greatest demonstration of God's love is revealed through the mission and ministry of Jesus. Jesus said that he came to fulfill the law (Matt 
5:17). Hence, Jesus came to accomplish the intention of the law. Therefore, the mission of Jesus encompasses a revelation of how to love God with all our hearts and our neighbors as ourselves. Whereas man's capacity to represent God was damaged by the fall, "Jesus is the express image of God" (Heb 1:3). Further, Jesus said, "If you have seen me you have seen the father "(John 14:9). Thus, in observing the mission and ministry of Jesus, we are also seeing God's perspective about loving all people.

In announcing his mission, Jesus said that he had being anointed to preach to the poor, heal the broken hearted, preach deliverance to the captives, recovery of sight to the blind and to set at liberty those that are bruised (Luke 4:18). Thus, the mission and ministry of Jesus included a revelation of love for the socioeconomically disadvantaged. Jesus' acts of caring for the socioeconomically disadvantaged reveal this love. Jesus extended this loving care to all peoples, including those who were not Jews. Jesus also gave this kind of compassionate care to people outside the borders of Israel.

Jesus did this type of service by mingling with men as one who desired their good. Moreover, he showed sympathy for them, ministered to their needs, won their confidence, and then requested that they follow him (E. G. White, 1952, p. 60). Thus, Christ was concerned about caring for the needs of the socioeconomically disadvantaged. In addition, to showing his care for the needy, Jesus also taught about caring for the socioeconomically disadvantaged. One example of his teaching on this subject is the story of the Good Samaritan. This story has many salient lessons. Some of these are that a neighbor is a person in need, and God's love is boundless. In addition, Christians should act in a similar manner to that of the Good Samaritan when they encounter those who are socially disadvantaged. This means observing and reaching out to the needs of others. 
They should rescue and restore the socially disadvantaged.

After the ascension of Jesus, the disciples followed the model of ministry that they were taught by Jesus. They followed the teaching of Jesus to love their neighbors as themselves. They did this in several ways, including sharing all things in common, inaugurating the ministry of the deacons, and making clothing for the poor. Like Jesus, the ministry of the New Testament Church entailed caring for the needs of the socioeconomically disadvantaged. Through caring for these needs, the church was able to reach people for Christ.

The legacy of the mission of God as revealed in the lives of faithful believers of the Old Testament and the laws given to the Old Testament Church shows that God cares for the socioeconomically disadvantaged. In the Old Testament, this caring was done by Job in the city in which he lived. Job lived at a time before the creation of the nation of Israel. After the creation of Israel, caring for the socioeconomically disadvantaged was done primarily within the commonwealth of Israel. Even though it was done in Israel, it included a person like Ruth, who was not a Jew.

In the New Testament, the legacy of the mission and ministry of Jesus and of the disciples includes caring for the needs of the socioeconomically disadvantaged inside and outside the church.

In following the model of the early disciples, the Seventh-day Adventist Church created the Community Ministries Department. The purpose of this department is to serve the poor and hurting in Jesus' name. Thus, included in the ministry mandate of the department is caring for the needs of people who are socioeconomically disadvantaged.

Currently, such a department exists at Toronto West Seventh-day Adventist 
Church. This department has tried to reach the people in its community through programs like a mid-week dinner and an annual thanksgiving dinner. The responses of people from the community to the programs were poor. As regards this poor response, I hypothesized that a strategic marketing plan might help solve the problem. A review of literature about marketing shows that churches can use marketing effectively to accomplish aspects of their mission that is non-salvific. In order to do this it is necessary to develop a strategic marketing plan. Developing a strategic marketing plan includes conducting a situation analysis, developing marketing strategies by utilizing the results from the situation analysis, and implementing and controlling the strategies of the marketing plan.

A strategic marketing plan was developed for the Community Services Department of Toronto West Seventh-day Adventist Church. In doing this, marketing research was done in the Etobicoke North Community. The marketing research was a qualitative study that included needs identification and analysis. The research included utilizing data from primary and secondary sources. The results from the research show that the ten top real and felt needs of this community are the same. These are security, income, education, food, employment, family support, health, English as a second language, housing, and recreation. Strategic market planning necessitates developing a strategic fit between an organization's resources and the opportunities of the marketing environment. Consequently, the resources that the department had were used to create ministries and products to offer the community. The strategic marketing plan was implemented on September 15, 2013, at the Annual Day of Love and Care Program. While 35 persons from the community attended the previous year's program, the results from the implementation of the plan showed that 145 persons registered for the program 
in 2013. In addition, the actual attendance at the program was 300 adults and 75 children from the community. Consequently, there was an increase of over 300\% in attendance at the program.

\section{Recommendations}

I have discovered through this project that there are many things that the church can do to improve its effectiveness in reaching people in the community for Christ. As a result, I offer the following recommendations, first to the local church, then to the world church. This will be followed by recommendations for further research.

\section{For Toronto West Seventh-day Adventist Church}

1. That the church establishes a food bank on it premises. The fact that the Community Services Department food resources were depleted before the end of the Day of Love and Care program shows that there is great need for food in the Etobicoke North Community.

2. The church needs to create and administer an English as a Second Language Program on it premises. The percentage of immigrants in the area whose mother tongue is not English necessitates the hosting of such a program.

3. There is a great need for security in the area. The church can partner with the security agencies and services in the area to hold security awareness programs for the community.

4. In this research, I discovered that North Etobicoke has a higher rate of the occurrence of diabetes than the average rate in the province of Ontario and some areas of the city of Toronto. The church can partner with the Ontario Conference Health 
Ministries Department, other non-profit health organizations, and the Government of Canada health department to conduct health programs for the community. These programs should address diabetes awareness and prevention.

5. Employment is one of the top needs in North Etobicoke. The area is also constantly undergoing a demographic transition due to the arrival of new immigrants. Therefore, the church can hold career fairs and job fairs to help people become aware of employment opportunities. In addition, the church can pursue the provision of childcare on it premises during the week. This would help parents who need to be away from home in order to find employment. It will also address an aspect of family support, which is one of the top ten needs of the community.

6. Etobicoke North is becoming a more multi-ethnic, multi-cultural, multireligious community. As a result, the church can conduct seminars on cultural awareness, cultural sensitivity, and cultural intelligence for the church members and persons from the community. This would enhance the communication of members from the community and members from the church when there are programs at the church.

7. The results of this research show that education is one of the top ten needs of the community. Since the church has many rooms, the church can partner with the government and non-governmental agencies to hold after-school classes for children from the community. In addition, the church can explore the establishment of adult education programs by partnering with institutions of higher learning. Such programs can benefit the many immigrants in the area who may need to find a new career. The church can also make the community aware of the existence and location of Seventh-day Adventist 
primary and secondary schools in Toronto. Further, the church can offer scholarships to these schools.

8. Another need of the community is recreation. The church can make its premises available to the community on some evenings during the week for recreational programs. Such programs can include basketball in the gymnasium/social hall during winter. The church can also use its parking lot to build a basketball/volleyball court. People from the community can be invited to play on the premises of the church. Since the church has several sports teams, it can offer free coaching to the youth in the community in these areas.

\section{For Other Churches}

This project has shown that churches can benefit by developing programs and services that have a strategic fit with the resources of the church and its community.

1. As a result, churches can develop a team of members to research the needs of their communities. I found that doing such research alone consumes a lot of time. Therefore, having a team do the research lightens the time load on each person. In cases where churches can afford it, they can employ a professional researcher or company to do the research. Having done this, the information from the research can be used to develop programs that are relevant and contextual to the community in which the church exists.

2. The world has become a global city. More people are migrating to cities As a result, many city churches today will find that they are ministering in a more diverse community than the one in which they were first planted. Such churches may find it helpful to develop training programs for their members and the community in cultural sensitivity and intelligences. 
3. Where it is in keeping with the mission and theology of the church, strategic marketing of non-salvific programs and services of the church can be used to enhance the effectiveness of the ministries of the church.

\section{Implication for Further Research}

1. There is a need for more academic research on the use and impact of strategic market planning in churches. I found that little research has been done in this area.

2. More research can be done in the area of resolving the impasse that exists between those who favour the use of marketing by churches and those who oppose it.

3. There is a need to research how religious marketing is different from other kinds of marketing.

\section{How I Have Grown Through This Project}

Thorough this project, I have grown in several ways. First, my knowledge in the area of strategic marketing for churches has increased. I have learned how to study and understand the community in which a church exists through the perspective of marketing. In addition, I have learned how to utilize the knowledge that was gained by studying the community to design and implement services and programs that are relevant to the needs of the community.

Second, I learned that different cultures and religions have shaped our understanding of food, clothing, and places, in different ways. For example, Hindus are traditionally vegetarians. Consequently, when we were preparing to provide food for the visitors on the community day, the staff of the Community Services Department had to be sensitized to this fact. As a result, this project has increased my cultural and religious 
intelligence. It has also made me more culturally sensitive.

Third, I discovered that there are numerous challenges faced by immigrants in the Etobicoke North area. For example, many first-time immigrants whose first language is not English find it challenging to find employment because most employers require knowledge of the English language as part of the applicant's qualifications. This has made me aware of the need to create church-based welfare support services for new immigrants to Toronto.

Fourth, I learned that many lay leaders of the church were never trained in strategic planning and strategic marketing. As a result, I had to acquire and develop training resources in these subjects while I was working on this project. This has increased my resource material and competency in these subjects.

Fifth, I was made more acutely aware of the devastating impact of poverty on the lives of people, the family, and the community in which they live.

Sixth, I discovered how migration changes the cultural, ethnic, and religious structure of a community and how the church needs to be educated in order to take into consideration these changes in its community when planning community services events.

Seventh, I learned the value of assessing the results of the implementation of a program. In addition, I learned how I can use the knowledge which was acquired from assessment to design or redesign future programs.

My intention is to use the knowledge that was gained during this project to help to grow the church in Canada. 
APPENDIX A

INFORMED CONSENT LETTER 


\section{Andrews University \\ Seventh-day Adventist Theological Seminary \\ Christian Ministries Department \\ Informed Consent Letter \\ Title: A STRATEGIC MARKETING PLAN FOR COMMUNITY MINISTRIES AT \\ TORONTO WEST SEVENTH-DAY ADVENTIST CHURCH}

Purpose of Study: I understand that the purpose of this study is to develop a strategic marketing plan for the Toronto West Seventh-day Adventist church so as to help it to become more effective in ministering to the needs of the Etobicoke North Community in Toronto Canada.

Inclusion Criteria: In order to participate, I recognize that I must be an adult between the ages of 18 and 75 and of sound mind, and must be known as a leader in my community.

Risks and Discomforts: I have been informed that there are no physical or emotional risks to my involvement in this study.

Benefits/Results: I accept that I will receive no remuneration for my participation, but that by participating, I will help the researcher and the Toronto West Seventhday Adventist Church arrive at a better understanding of how to develop a strategic marketing plan to minster to the needs of it community.

Voluntary Participation: I understand that my involvement in this survey is voluntary and that I may withdraw my participation at any time without any pressure, embarrassment, or negative impact on me. I also understand that participation is anonymous and that neither the researcher nor any assistants will be able to identify my responses to me.

Contact Information: In the event that I have any questions or concerns with regard to my participation in this research project, I understand that I may contact either the researcher, Allan Chichester 905-832-6817 or his advisor, Dr. David Penno, professor in Church Ministries at penno@andrews.edu (1-269-471-6366). I have been given a copy of this form for my own records.

Sincerely,

Date 
APPENDIX B

RESEARCH INSTRUMENT 


\section{Andrews $\mathbb{Q}$ University}

Seventh-day Adventist Theological Seminary

Christian Ministries Department

\section{Title: A STRATEGIC MARKETING PLAN FOR COMMUNITY MINISTRIES} AT TORONTO WEST SEVENTH-DAY ADVENTIST CHURCH

\section{Research instrument}

Kindly list below the ten real needs and ten felt needs of the Etobicoke North Area in Toronto Canada.

1.

2.

3.

4.

5.

6.

7.

8.

9.

10.

1.

2.

3.

4.

5.

6.

7.

8.

9.

10.

State which needs are the most important? 
APPENDIX C

REGISTRATION FORM 


\section{REGISTRATION FORM}

LOVE AND DAY CARE

Name:

Address:

Phone Number

1. How did you find out about this event?

Please circle the appropriate answer.

- Flyers/lawn signs

- Radio

- Newspaper

- Friend

- $\quad$ Other

2. How can we better serve you?

Thank you. 
APPENDIX D

IRB EXEMPTION LETTER 


\section{Andrews $\$$ University}

May 30, 2012

Allan Chichester

RE: APPLICATION FOR APPROVAL OF RESEARCH INVOLVING HUMAN SURJECTS IRB Protocol z: 12-084 Application Type: Original Dept.: Doctor of Ministry Review Category: DMin Exempt Action Taken: Approved Advisor: David Penno Title: A Strategic Marketing Plan for Community Ministries at the Toronto West Seventhday Adventist Church

Thank you for submitting your IRB application for approval of research involving human subjects entitled: "A Strategic Marketing Plan for Community Mimistries at the Toronto West Seventh-day Adventist Chrrch" IRB protocol \#12-084. We would like to inform you that your study has been evaluated and determined to be Exempt from IRB review according to Andrews University guidelines for the Doctor of Ministry Exempt status. You may now proceed with your project.

Please note that any future changes made to the study design and/or consent form require prior approval from the IRB before such changes can be implemented.

While there appears to be no more than minimum risk with your study, should an incidence occur that results in a research-related adverse reaction and/or physical injury, this must be reported immediately in writing to the IRB. Any research-related physical injury must also be reported immediately to the University Physician, Dr. Hamel, by calling (269) 473-2222.

We ask that you reference the protocol number in any future correspondence regarding this study for easy retrieval of information.

Please do not hesitate to contact us if you have questions.

Best wishes in your studies.

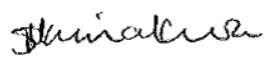

Sarah Kimakwa

IRB, Research \& Creative Scholarship

Institntional Review Board - 4150 Adninistration Dr Roon 322 - Berrien Springs, MI 491040355 Tel: (269) 471-6361 Fax: (269) 471-6543 E-mail: irb@andrews.edn 
APPENDIX E

EXPERIENCE THE LOVE FLIER 


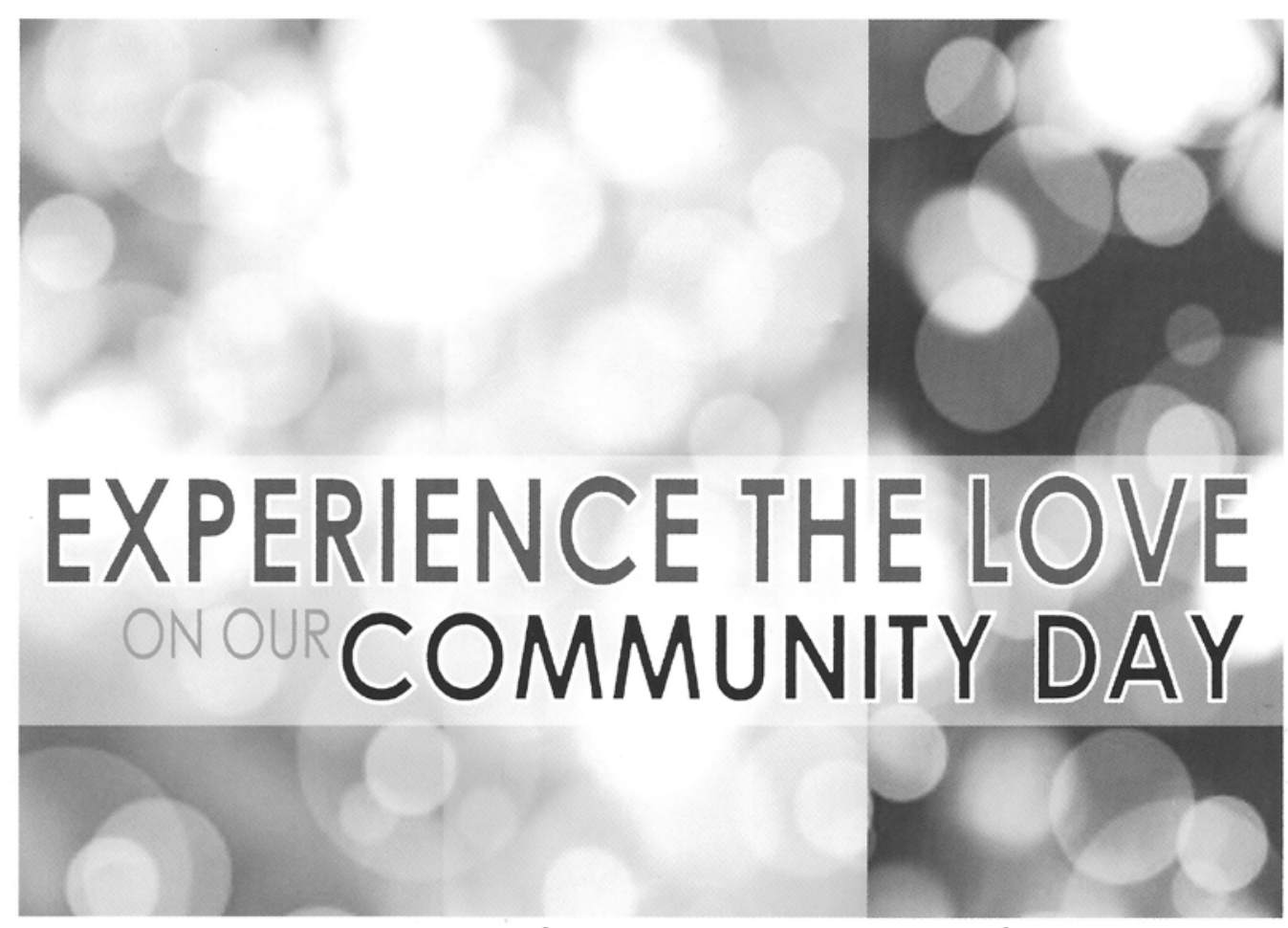

1621 Albion Rd, Toronto | September 15, 2013 | 12pm-5pm

\section{6-401-0030 | ADMIN@TORONTOWEST.ORG}

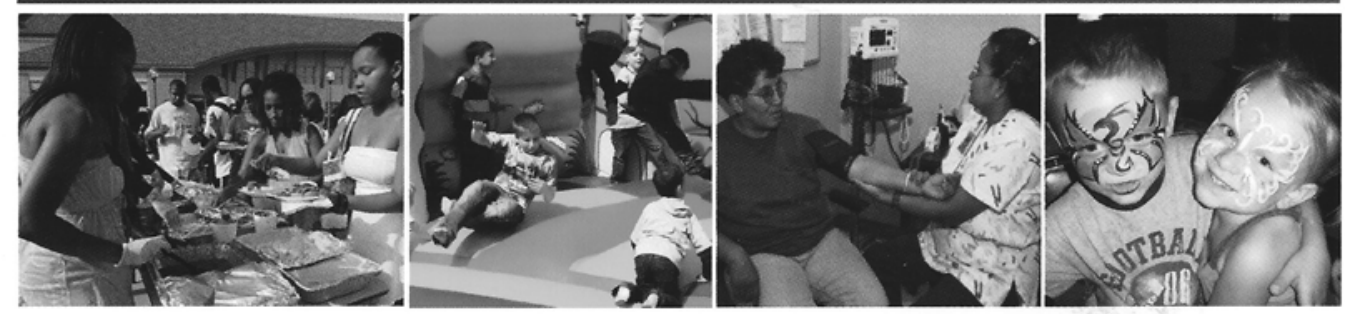

\section{FREE COMMUNITY EVENT}

Collect free clothing | Collect free food items | Enjoy a free cooked meal | Enjoy a free massage Discover how to prevent \& cope with diabetes \& high blood pressure | Enjoy free children games Bring your family, friends, \& neighbours 


\section{REFERENCE LIST}




\section{REFERENCE LIST}

Achtemeier, P. J. (1985a). Mercy. In Harper's Bible dictionary (1st ed.). San Francisco, CA: Harper \& Row.

Achtemeier, P. J. (1985b). Poor. In Harper’s Bible dictionary (1st ed.). San Francisco, CA: Harper \& Row.

Achtemeier, P. J. (1985c). Stranger. In Harper's Bible dictionary (1st ed.). San Francisco, CA: Harper \& Row.

Achtemeier, P. J. (1985d). Widow. In Harper's Bible dictionary (1st ed.). San Francisco, CA: Harper \& Row.

Acts 4:32. (1962). In C. F. Pfeiffer \& E. F. Harrison, The Wycliffe Bible commentary: New Testament. Logos Bible Software 5.2b SR-9. Faithlife.

Adams, R. (2000, June). Mother of churches. Adventist Review, 177(22), 39.

Alston, M., \& Bowles, W. (2003). Research for social workers: An introduction to methods (2nd ed.) New York, NY: Routledge.

Andresean, A., \& Kotler, P. (2003). Strategic maketing for non-profit organizations (6th ed.). Upper Saddle River, NJ: Prentice Hall.

American Marketing Association. (2011). Marketing. In Definitions of marketing. Retrieved from http //www.ama.org/AboutAMA/Pages/Definition-ofMarketing.aspx

Armstrong, G., Kotler, P., Cunningham, P., Mitchell, P., \& Buchwitz, L. A. (2007). Marketing: An introduction (2nd ed.). Toronto, ON, Canada: Prentice Hall.

Barker, A. (2009). Make poverty personal: Taking the poor as seriously as the Bible does. Grand Rapids, MI: Baker.

Bedburry, S. (2002). A new brand world. New York, NY: Penguin.

Bennett, A. G. (2010). The big book of marketing. Chicago, IL: McGraw-Hill. 
Berkowitz, E. N., Crane, F. G., Kerin, R. A., Hartley, S. W., \& Rudelius, W. (2003). Marketing (5th ed.). Toronto, ON, Canada. McGraw-Hill Ryerson.

Bethune, E., \& Wang, S. (2010). Highlights of consultations and surveys. Toronto, Canada: North Etobicoke Local Immigration Partnership.

Brennan, R., Baines, P., Garneau, P., \& Vos, L. (2008). Contempory strategic marketing (2nd ed.). New York, NY: Palgrave MacMillan.

Capps, K. (2009). The good news of the kingdom of God and the poor: A biblicaltheological investigation of a Lukan paradigm (Doctoral dissertation). Available at ProQuest Dissertations and Theses, 130. (305158794) Retrieved from http://search.proquest.com/docview/305158794?accountid=8313

Caesar, L. (2000). Job a paradigm of the escathon. Journal of Adventist Theological Society, 11(1-2), 148-162. Retrieved from http://www.atsjats.org/publication _file.php?pub_id=112\&journal=1\&type=pdf

Carson, D. A., France, R. T., Motyer, J. A., \& Wenham, G. J. (Eds.). (1994). New Bible commentary: 21st century edition. Downers Grove, IL: Inter-Varsity Press.

City of Toronto. (2003, September). Ward profiles, Ward 1, 2001. Retrieved from http://www1 .toronto.ca/city_of_toronto/city_planning/wards/files/pdf/ wardprofiles_01.pdf

City of Toronto. (2008). Ward profiles, Ward 1, 2006. Retrieved from http://www1 .toronto.ca/city_of_toronto/city_planning/wards/files/pdf/ward1_2006profiles.pdf

City of Toronto. (2014). Neighborhood demographics estimates, Mount OliveSilverstone-Jamestown. Retrieved from http://tinyurl.com/my6cj8z

City of Toronto. (2014). Neighborhood census NHS profile. West Humber Claireville. Retrieved from http://tinyurl.com/nabppdb

Claerbaut, D. (2005). Urban ministry in a new millennium. Waynesboro, GA: Authentic Media.

Considine, J. (2001a). Benefits of a market orientation for religious organizations. Journal of Ministry Marketing and Management, 7(1), 33-41.

Considine, J. (2001b) . Developing a marketing plan for a religious organization. Journal of Ministry Marketing \& Management, 7(2), 51-67.

Davidson, J. A. (2001). Even if Noah, Daniel and Job Ezekiel $(14: 14,20)$ - Why these three? Journal of the Adventist Theological Society, 12(2), 132 - 144. Retrieved 
from https://www.andrews.edu/sem/faculty_staff/faculty/jo-anndavidson/noah_daniel_job_jats_12-2_fall_01.pdf

Day, D. (1990). A guide to marketing Adventism. Nampa, ID: Pacific Press.

Dybdahl, J. L. (2005, November). Doing theology in mission. Ministry: International Journal for Pastors, 77(11), 19. Retrieved from https://www.ministry magazine.org/archive/2005/November/doing-theology-in-mission.html

Diversity-Toronto facts. (n.d.). Retrieved from http://tinyurl.com/nxsbp5e

Drummond, G., Ensor, J., \& Ashford, R. (2008). Strategic marketing (3rd ed.). Jordan Hill, Oxford, England: Butterworth-Heinemann.

East, R., Wright, M., \& Vanhuele, M. (2008). Consumer behaviour: Applications in marketing. Los Angeles, CA: Sage.

Easton, M. G. (1996). Alien. In Easton’s Bible dictionary. Oak Harbor, WA: Logos Research Systems.

Ellsworth, D. O. (1976). Confronting Christian responsibility: Exegesis and application of Luke 10:29-37. The good Samaritan example story. Retrieved from search.proquest.com.ezproxy.cc.andrews.edu/pqdtglobal/docview/288107070/ED C54A65FE114F21PQ/6?accountid=8313

Foote, C. (2012). The creative business guide. New York, NY: Norton.

Gay, L. R., Mills, G. E., \& Airasian, P. W. (2012). Educational research: Competencies for analysis and application (10th ed.). Upper Saddle River, NJ: Prentice Hall.

Gilligan, C., \& Wilson, R. (2009). Strategic marketing planning. Jordan Hill, United Kingdom: Butterworth-Heinemann.

Goal. (2013, November 10). Retrieved from http://www.businessdictionary .com/definition/goal.html

Griffin, E. (2007). Business essentials (6th ed.). Upper Saddle River, NJ: Pearson.

Grenz, S. J., \& Olson, R. E. (1992). 20th century theology: God and the world in a transitional age. Downers Grove, IL: Intervarsity Press.

Grudem, W. (1994). Systematic theology: An introduction to biblical doctrine. Grand Rapids, MI: Zondervan.

Guder, D. L. (Ed.). (1998). Missional church: A vision for the sending of the church in North America. Grand Rapids, MI: Eerdmans. 
Hamilton, V. P. (1982). Handbook on the Pentateuch: Genesis, Exodus, Leviticus, Numbers, Deuteronomy. Grand Rapids, MI: Baker Academics.

Hamper, R. J. (2014). The ultimate guide to strategic marketing: Real world methods for developing successful long-term marketing lans. New York, NY: McGraw Hill.

Hoppe, L. J. (2004). There shall be no poor amongst you: Poverty in the Bible. Nashville, TN: Abingdon Press.

Hughes, D. (2008). Power and poverty: Divine rule and human rule in a world of need. Downers Grove, IL: InterVarsity Press.

Hulchanski, D. J. (2007). The three cities within Toronto: Income polarization among Toronto's neighbourhoods, 1970-2005. Toronto, Canada: Cities Centre Press.

Hurtig, M. (1999). Pay the rent or feed the kids: The tragedy and disgrace of poverty in Canada. Toronto, Canada: McClelland \&Stewart.

Keil, C. F., \& Delitzsch, F. (1996). Commentary on the Old Testament (Vol. 4). Peabody, MA: Hendrickson.

Keltner, G. R. (2012). The views of selected church leaders regarding the church's responsibility to social issues with a proposed biblical paradigm (Doctoral dissertation). Available from ProQuest Dissertations and Theses database. (UMI No. 3530501)

King, K., Hracs, B., Denstedt, M., \& Bednar, V. (2010). Diversity our strength. Toronto 2010 Elections: Discussion Paper \# 3-August 2010. Toronto, Canada: University of Toronto, Martin Prosperity Institute.

Kittel, G., Friedrich, G., \& Bromiley, G. (1995). Widow. In Theological dictionary of the New Testament. Grand Rapids, MI: Eerdmans.

Kittel, G., Friedrich, G., \& Bromiley, G. (1995). Orphans. In Theological dictionary of the New Testament. Grand Rapids, MI: Eerdmans.

Kotler, P., Armstrong, G., \& Cunningham, P. H. (2005). Principles of marketing (6th ed.). Toronto, ON, Canada: Pearson Prentice Hall.

Kotler, P., \& Keller, K. L. (2006). Marketing management (12th ed.). Upper Saddle River, NJ: Pearson Education.

Kotler, P., Kartajawah, K., \& Seitewan, I. (2010). From products to customer to the human spirit. Hokoben, NJ: Wiley. 
Kurtz, D. L. (2008). Contemporary marketing (13th ed.). Mason, OH: Thompson SouthWestern.

Kuzma, A., Kuzma, A., \& Kuzma, J. (2009). How religion has embraced marketing and the implications for business. Journal of Management and Marketing Research, 2, $1-11$.

Kvale, S. (2007). Doing intervews. Los Angeles, CA: Sage.

Lake, L. (2011). Strategic market planning. Retrieved from http://tinyurl.com/7umcal4

Linrud, D. (Ed.). (2013). Ontario Conference directory. Oshawa, ON, Canada: Communications Department.

Levine, A-J. (2014). Short stories by Jesus: The enigmatic parables of a controversial rabbi. New York, NY: Harper Collins.

Longenecker, B. W. (2010). Remember the poor: Paul, poverty, and the Greco-Roman world. Grand Rapids, MI: Eerdmans.

MacDonnell, S., Robinson, J., Mikadze, V., McDonough, V., \& Meisner, A. (2011). Vertical poverty: Poverty by postal code 2. Declining income, housing quality and community life in Toronto's inner suburban high-rise apartments. Toronto, Canada: United Way.

McDonald, M. B., \& Keegan, W. J. (2002). Marketing plans that work (2nd ed.). Boston, MA: Butterworth-Heineman.

McDonald, M. (2007). Marketing plans: How to prepare them, how to use them. Burlinton, MA: Elsevier.

McDonald, M., \& Hugh, W. (2011). Marketing plans: How to prepare them, how to use them (7th ed.). Chichester, United Kingdom: Wiley

Macintyre, J. B., \& Bardwaj, K. B. (2011). The world needs Toronto to succeed. Retrieved from https://torontofoundation.ca/world-needs-toronto-succeed.

Matern, R. (2013). Who's hungry: Faces of hunger, 2012 profile of hunger in the GTA. Daily Bread Food Bank.

Ministerial Association, General Conference of Seventh-day Adventists. (1988). Seventhday Adventists believe: A biblical exposition of 27 fundamental doctrines. Hagerstown, MD: Review and Herald.

Mission. (n.d.). Toronto West Seventh-day Adventist Church. Retrieved from http://torontowestsda.org/AboutUs/Mission/tabid/2229/Default.aspx 
Moore, K., \& Pareek, N. (2006). Marketing the basics. New York, NY: Routledge. Moskala, J. (2008). The mission of God's people in the Old Testament. Journal of the Adventist Theological Society, 19(1-2), 40-60. Retrieved from http://www.atsjats.org/publication_file.php?pub_id=336\&journ

Nayar, R. (2010). North Etobicoke local immigration partnership: Community snapshot. Toronto, Canada: Nayar Consulting.

Nichol, F. D. (Ed.) (1980a). Amos. In Seventh-day Adventist Bible commentary (Vol. 4, p. 954). Hagerstown, MD: Review and Herald.

Nichol, F. D. (Ed.) (1980b). Deuteronomy. In Seventh-day Adventist Bible commentary (Vol. 1, p. 1,003). Hagerstown, MD: Review and Herald.

Nichol, F. D. (Ed.) (1980c). Exodus. In Seventh-day Adventist Bible commentary (Vol. 1, p. 623). Hagerstown, MD: Review and Herald.

Nichol, F. D. (Ed.) (1980d). Job. In Seventh-day Adventist Bible commentary (Vol. 3, p. 494). Hagerstown, MD: Review and Herald.

Nichol, F. D. (Ed.) (1980e). Leviticus. In Seventh-day Adventist Bible commentary (Vol. 1, p. 811). Hagerstown, MD: Review and Herald.

Nichol, F. D. (Ed) (1980f). Luke. In Seventh-day Adventist Bible commentary (Vol. 5, pp. 728, 782). Hagerstown, MD: Review and Herald.

Objective. (2013, November 10). Retrieved from http://www.businessdictionary .com/definition/objective. html

Ogilvie, M. (2012). New map reveals diabetes hot spot in the GTA. Retrieved from http:// www.thestar.com/life/health_wellness/20120424/ new_map_reveals_diabetes_hot_spot_in_the_gta.html

Onyenemezu, E. C., \& Olumati, E. S. (2013). The imperatives of felt-needs in community development. Journal of Education and Practice, 4(3) 157, Retrieved from http://www.iiste.org/Journals/index.php /JEP/article/view/4083/4116

Paley, N. (2000). How to develop a strategic marketing plan: A step by step guide. New York, NY: St. Lucie.

Parry, M. E. (2005). Strategic market management. Chicago, IL: McGraw-Hill.

Polonshy, M. J., \& Waller, D. S. (2011). Designing and managing a research project: A business student guide. Thousand Oaks, CA: Sage. 
Proctor, T. (2008). Strategic marketing. New York, NY: Routledge

Qualitative research. (n.d.). In Wikipedia, the free enclycopedia. Retrieved from http://en.wikipedia.org/wiki/Qualitative_research

Richards, L., \& Richards, L. O. (1987). The teacher's commentary. Wheaton, IL: Victor.

Reising , R. (2006). Church marketing 101: Preparing your church for greater growth. Grand Rapids, MI: Baker.

Ryans, A., More, R., Barcaly, D., \& Terry, D. (2000). Winning market leadership: Strategic market planning for technology-driven business. Etobicoke, ON, Canada: Wiley.

Sahlin, M., Gavin, J., Washington, F., Williams, G., Chavanz-Q, J., Moyer, M., Calkins, A., Calkins, J., Johnson, J. A., \& Watkins, C., (1994). Ministries of compassion: A handbook for Adventist community services, inner city programs and social action projects. Lincoln, NE: Church Resources Consortium, North American Division of the General Conference of the Seventh-day Adventist Church.

Sahlin, M. (2004). Undersatnding your community. Lincoln, NE: Center for Creative Ministry.

Saldana, J. (2011). Fundamentals of qualitative research:Understanding qualitiative research. New York, NY: Oxford University Press.

Sandusen, R. L. (2008). Marketing (4th ed.). Hauppage, NY: Barron.

Seim, B. (2013). Diaspora and the megacities: A narrative mode. In J. T. Sadira (Ed.), The human tidal wave (pp. 67-114). Manila, Philippines: Life Change.

Slick, M. (n.d). Theology. In dictionary of theology. Retrieved from https://carm.org/dictionary-theology

Sommers, M. S., \& Barnes, J. G. (2001). Fundamentals of marketing (9th ed.). Toronto, ON, Canada: McGraw-Hill Ryerson.

Smith, B. (2005). Making marketing happen: How great companies make strategic marketing planning work for them. Burlington, MA: Elsevier Butterman Heineman.

State Library of New South Wales (2014). People who are socioeconomically Disadvantaged. In Preliminary part III: HSC legal studies. Retrieved from http://guides.sl.nsw.gov.au/content.php?pid=334636\&sid=2737563 
Statistics Canada. (2012). Visible minority of person. Ottawa, ON, Canada: Author.

Retrieved from http://www.statcan.gc.ca/concepts/definitions/minority-minorite1eng.htm

Thompson, A., Jr., Strickland, A., III, \& Gamble, J. (2008). Crafting \& executing strategy: The quest for competitive advantage (16th ed.). New York, NY: McGraw-Hill Erwin.

Twitchell, J. B. (2004). Branded nation: The marketing of megachurch, College Inc, and museumworld. New York, NY: Simon \& Schuster.

Vyhmeister, N. (1990, August). Why world mission? Ministry: International Journal for Pastors. Retrieved from https://www.ministrymagazine.org /archive/1990/August/why-world-mission

Walvoord, J. F., \& Zuck, R. B. (1983). The Bible knowledge commentary: An exposition of the Scriptures. Wheaton, IL: Victor Books.

Watkins, D. R. (1994). Christian social ministry: An introduction. Nashville, TN: Broadman and Holman.

Webster, D. D. (1992). Selling Jesus: What is wrong with marketing the church. Downers Grove, IL: Intervarsity Press.

Webster. (2006). Poor. In Webster's English dictionary: Concise edition for school, home and office. Toronto, ON, Canada: Strathearn.

West, D., Ford, J., \& Ibrahim, E. (2010). Strategic marketing: Creating competitive advantage (2nd ed.). New York, NY: Oxford University Press.

Westwood, J. (2008). How to write a marketing plan (3rd ed.). Philadelphia, PA: Kogan Page.

White, B. (2000). Dissertation skills for business and management students. Singapore: Thompson.

White, E. G. (1890). Patriarchs and prophets. Mountain View, CA: Pacific Press.

White, E. G. (1905). Ministry of healing. Mountain View, CA: Pacific Press.

White, E. G. (1911). The acts of the apostles. Mountain View, CA: Pacific Press.

White, E. G. (1940). The desire of ages. Mountain View, CA: Pacific Press.

White, E. G. (1946). Evangelism. Washington, DC: Review and Herald.

White, E. G. (1948). Testimonies to the church (Vol. 6). Boise, ID: Pacific Press. 
White, E. G. (1952). Welfare ministry. Washington.

Wigg-Stevenson, T. (2009, January 1). Jesus is not a brand. Retrieved from http://christianitytoday.com

Withers, W., \& Vipperman, C. (2003). Marketing your service. North Vancouver, BC, Canada: Self-Counsel Press.

Wrenn, B., Stevens, R., \& Loudon, D. (2002). Marketing research text and cases. New York, NY: Best Business Books.

Wrenn, B., Kotler, P., \& Shawchuck, P. (2010). Building strong congregations: Attracting serving, and developing your membership. Hagerstown, MD: Autumn House.

Wrenn, B. (2011). Religious marketing is different. Service Marketing Quarterly, 32(1), 44-59.

Wrenn, B., Harwood, H., Jr., \& Warwick, J. (2013). Scriptural foundations for marketing. Berrien Springs, MI: Andrews University Press.

Zeithaml, V. A., Bitner, M. J., \& Gremler, D. D. (2006). Services marketing: Integrating customer focus across the firm. New York, NY: McGraw-Hill Irwin. 
VITA 
VITA

Name: Allan Roy Chichester

Date of Birth: November 8, 1962

\section{Education}

2011 - Present Doctor of Ministry, Andrews University, Berrien Springs, MI 1998 - 1999 Master of Arts in Religion, Andrews University, Berrien Springs, MI

1986 - 1991 Bachelor of Arts in Theology, Caribbean Union College, Andrews University Extension Campus, Trinidad, West Indies

1981 - 1982 Military Officer Certificate, Comrade Uric Pilgrim Officers Cadet School, Timehri, Guyana

\section{Ordained:}

December 1994 Guyana Conference of Seventh-day Adventists

Currently

Holding credentials from Ontario Conference of Seventh-day Adventists

\section{Work Experience}

2014 - Present Senior Pastor, Toronto Central Seventh-day Adventist Church

2014 - Present Ministerial Field Secretary, Metro South Central District, Ontario Conference of Seventh-day Adventists

2006 - 2013 Senior Pastor, Toronto West Seventh-day Adventist Church

2001 - 2005 Senior Pastor, Kingsview Village Seventh-day Adventist Church

1997 - $2001 \quad$ Senior Pastor, Caribbean Union College Church

1996 - 2001 Acting Director of Religious Affairs, Caribbean Union College, Trinidad, WI

1994 - 1996 Associate Youth Director for Senior Youth Ministry, Guyana Conference of Seventh-day Adventists

1991 - 1996 Senior Pastor, Upper East Coast District, Guyana Conference of Seventh-day Adventists

1991

Senior Pastor, New Life Seventh-day Adventist Church, Guyana Conference of Seventh-day Adventists

1990 - 1991 Youth Pastor, Georgetown \# 1 District, Guyana Conference of Seventhday Adventists 